NATÁLIA ARAÚJO PAIVA

CITOTOXICIDADE DE CURCUMINA PRESENTE EM NANOPARTICULAS DE QUITOSANA/SULTATO DE CONDROITINA CONTENDO LECITINA

$$
\text { Brasília - DF }
$$

2015

Universidade de Brasília 
Faculdade UnB - Planaltina

Pós-Graduação em Ciências dos Materiais

\section{NATÁLIA ARAÚJO PAIVA}

\section{CITOTOXICIDADE DE CURCUMINA PRESENTE EM NANOPARTICULAS DE QUITOSANA/SULTATO DE CONDROITINA CONTENDO LECITINA}

Dissertação apresentada como requisito para a obtenção do Título de mestre em Ciências de Materiais pelo Programa de Pós-Graduação em Ciências de Materiais da Universidade de Brasília Faculdade UnB - Planaltina

Orientador: Prof. Dr. Alexandre Luis Parize Co orientadora: Profa. Dra. Marcella Lemos Bretas

Brasília-DF

2015 


\title{
CITOTOXICIDADE DE CURCUMINA PRESENTE EM NANOPARTICULAS DE QUITOSANA/SULTATO DE CONDROITINA CONTENDO LECITINA
}

\author{
Dissertação apresentada como requisito para a \\ obtenção do Título de mestre em Ciências de \\ Materiais pelo Programa de Pós-Graduação em \\ Ciências de Materiais da Universidade de Brasília - \\ Faculdade UnB - Planaltina
}

Aprovada em: 03/07/2015

BANCA EXAMINADORA

Prof. Dr. Alexandre Luis Parize

Universidade de Brasília

Profa. Dra. Marcella Lemos Bretas Carneiro

Universidade de Brasília

Profa. Dra. Renata Aquino da Silva de Souza

Universidade de Brasília

Profa. Dra. Tatiana Barbosa Rosado Laviola

Universidade de Brasília 
A Deus, aos meus pais Maria Helena e Cícero e a todos os amigos, pelo apoio, amor e incentivo constante. 


\section{AGRADECIMENTOS}

A Deus, por me amparar nos momentos difíceis, me dar força interior para superar as dificuldades, mostrar o caminho nas horas incertas e suprir todas as minhas necessidades.

Aos meus pais, que sempre primaram pela minha educação e por todos os ensinamentos, valores e compreensão durante toda esta caminhada.

Ao meu orientador Dr. Alexandre Luís Parize, pela oportunidade, por toda paciência, compreensão e ensinamentos durante todo esse tempo de convívio. Agradeço ainda por sua competência e dedicação em cada etapa deste trabalho e por não minimizar esforços para a conclusão deste.

A Katiúscia Vieira Jardim por sua ajuda constante, por acreditar no futuro deste projeto, contribuir para o meu crescimento e por ser um exemplo a ser seguido. Sua participação foi fundamental para a realização deste trabalho

A professora Dra. Marcella Lemos Bretas Carneiro, pela sua disponibilidade, pelo curso oferecido de cultura de célula e por toda colaboração neste projeto.

A professora Dra. Sônia Bao e sua aluna Joseilma Siqueira do Instituto de Biologia da Universidade de Brasília, pela colaboração, disponibilidade e supervisão durante os testes de viabilidade celular.

A Tatiane Oliveira do Laboratório de Microscopia de Alta resolução do Instituto de Física da Universidade Federal do Goiás, pela colaboração, paciência e dedicação durante as análises de microscopia.

Aos amigos que fizeram parte desses momentos sempre me ajudando e incentivando.

Aos colegas de trabalho pela paciência, estímulo e compreensão.

A Universidade de Brasília - Campus Planaltina, pela oportunidade.

Aos professores da banca, pela participação e colaboração.

E a todas as pessoas que contribuíram direta ou indiretamente, para a conclusão deste trabalho. Muito obrigada a todos. 


\section{RESUMO}

O objetivo desse estudo consistiu em avaliar o efeito da adição da lecitina de gema do ovo nas características de nanopartículas (NPs) de quitosana (QTS) e sulfato de condroitina (SC), empregadas na encapsulação da curcumina, bem como avaliar a atividade citotóxica in vitro da curcumina, utilizando linhagem de célula tumoral humana de mama MCF-7. A preparação das NPs de QTS/SC e QTS/SC/Lecitina padrão e contendo curcumina foi realizada pelo método de gelatinização iônica, considerando-se o estudo de especiação, que evidencia o pH ideal para maior interação dos biopolímeros com base no pKa teórico dos biopolímeros. As NPs obtidas apresentam boa estabilidade físico-química quanto ao diâmetro hidrodinâmico, PDI, potencial zeta e $\mathrm{pH}$ durante o período de 90 dias em diferentes temperaturas de acondicionamento $\left(4^{\circ} \mathrm{C}\right.$ e $\left.25^{\circ} \mathrm{C}\right)$. As características finais das NPs foram diretamente influenciadas pela adição de lecitina e pelo pH dos biopolímeros, determinado no estudo de especiação. As NPs foram também caracterizadas por meio das técnicas de microscopia eletrônica de transmissão, FTIR e TGA, observando-se a formação de NPs esférica, compactas e termicamente estáveis. A eficiência de encapsulação da curcumina nas NPs de QTS/SC e QTS/SC/Lecitina foi de 78,6 \pm 0,36 \% e 87,5 \pm 0,51\%, respectivamente, demonstrando que a adição da lecitina nas NPs influência de forma direta a encapsulação do fármaco. A liberação da curcumina foi conduzida em solução fosfato em pH 6,8, e ocorre de forma rápida nas primeiras horas e em seguida passa a ser de forma lenta e gradual, via mecanismo de difusão Fickiana, observando uma liberação mais acelerada através das NPs de QTS/SC/Lecitina. A avaliação da atividade citotóxica in vitro da curcumina foi realizada empregando-se o teste de MTT, observando-se que a curcumina livre e nanoencapsulada em QTS/SC e QTS/SC/Lecitina reduziu para 19,2; 36,4 e 23,8 \% (p<0,0001), respectivamente a viabilidade da célula MCF-7 no período de 72 horas. Os resultados indicam que NPs de QTS/SC/Lecitina são mais adequadas para encapsulação da curcumina.

Palavras chaves: Gelatinização iônica, nanopartículas, quitosana, sulfato de condroitina, curcumina, lecitina e avaliação citotóxica. 


\begin{abstract}
The aim of this study was evaluated the effect of lecithin addition in chitosan (QTS) and chondroitin sulfate (CS) nanoparticles characteristics (NPs) used in the curcumin encapsulation. Evaluate in a second part the curcumin cytotoxic activity in vitro using human breast tumor cell (MCF-7). The preparation of QTS/SC and QTS/S C /lecithin NPs standard and containing curcumin was performed by ionic gelation method, considering the speciation study, which shows the ideal $\mathrm{pH}$ for biopolymers interaction based on the theoretical $\mathrm{pKa}$ of biopolymers. NPs have good physico-chemical stability in different storage temperatures $\left(4^{\circ}\right.$ $\mathrm{C}$ and $25^{\circ} \mathrm{C}$ ) during the period of 90 days. The final characteristics of NPs, were directly influenced by the addition of lecithin and the $\mathrm{pH}$ of biopolymers used in the NPS preparation (speciation study). NPs were also characterized by TEM, FTIR and TGA, observing the formation of spherical NPs, compact and thermally stable. The encapsulation efficiency of curcumin NPs CTS / CTS and SC / SC / lecithin was 78,6 $\pm 0,36 \%$ and 87,5 \pm 0,51\%, respectively, show that the addition of lecithin improve the curcumin encapsulation in NPs. Curcumin release was conducted in a phosphate buffer solution $\mathrm{pH} 6.8$, and occurs rapidly in the initial time and then becomes slow and gradual way, through Fickian diffusion mechanism, observing a faster release through the NPs CTS / SC / Lecithin. The curcumin evaluation of the in vitro cytotoxic activity was carried out using the MTT assay, observing that the free curcumin and nanoencapsulated in QTS/SC and QTS/SC/ Lecithin reduced to 19.2; 36.4 and $23.8 \%$ ( $\mathrm{p}<0.0001$ ), respectively, the viability of MCF-7 cells in 72 hours. The results indicate that QTS/SC/ lecithin NPs are suitable for encapsulation of curcumin.
\end{abstract}

Keywords : ionic gelation, nanoparticles, chitosan, chondroitin sulfate , curcumin , lecithin and cytotoxic evaluation. 


\section{SUMÁRIO}

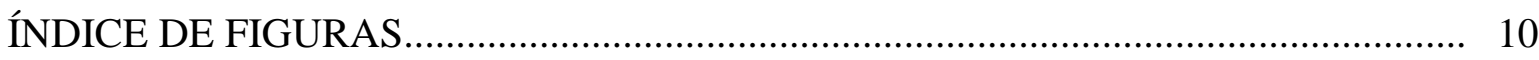

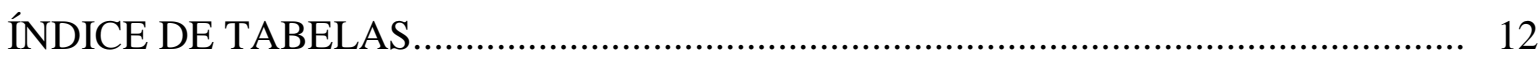

ÍNDICE DE EQUAÇÕES................................................................................. 13

LISTA DE SIGLAS, SÍMBOLOS E ABREVIATURAS............................................... 14

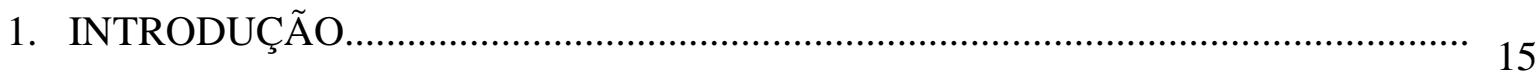

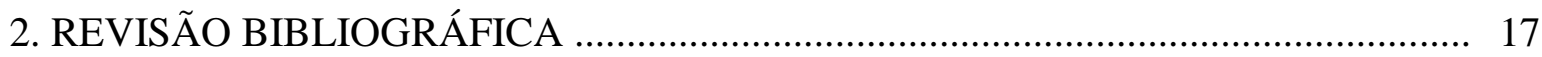

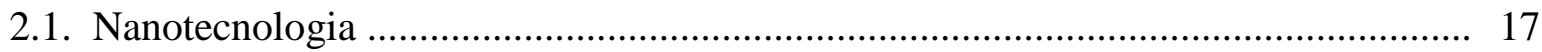

2.2. Nanopartículas poliméricas e a sua produção ………………………………….... 17

2.3. Biopolímeros …………………………………....................................... 19

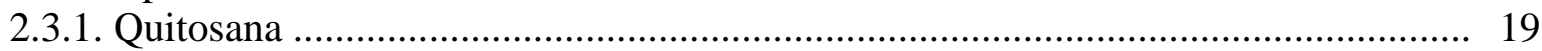

2.3.2. Sulfato de Condroitina ………………………........................................... 22

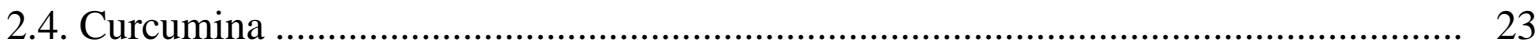

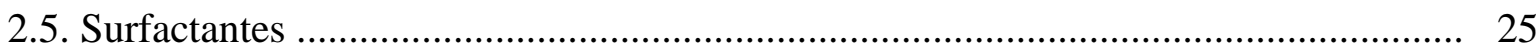

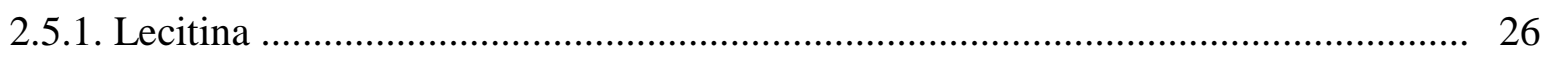

2.6. Liberação controlada de fármacos ...................................................................... 27

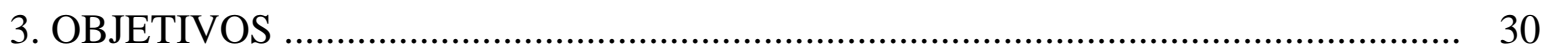

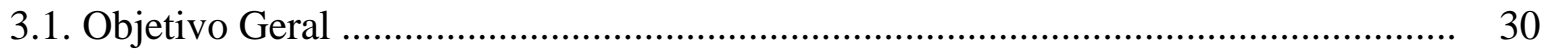

3.2. Objetivos Específicos................................................................................... $\quad 30$

4. MATERIAIS E MÉTODOS....................................................................................... 31

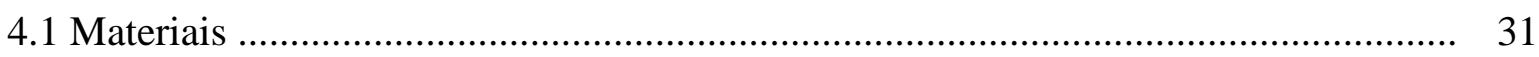

4.2. Métodos ................................................................................................... 31

4.2.1. Determinação do grau de desacetilação da quitosana (\%GD)................................. 31

4.2.2. Espectroscopia de absorção molecular UV-Vis para a curcumina........................... 33

4.2.3. Curva padrão de calibração da curcumina............................................................. 33

4.2.4. Preparação das nanopartículas........................................................................... 34

4.2.5. Caracterização das nanopartículas.................................................................... 40

4.2.5.1. Determinação do diâmetro hidrodinâmico, PDI e potencial zeta das nanopartículas........................................................................................... 40

4.2.5.2. Avaliação da estabilidade físico-químicas das nanopartículas em

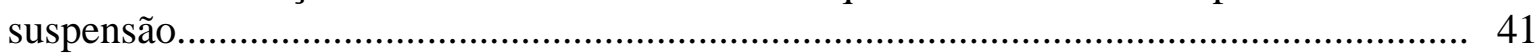

4.2.5.3. Eficiência de encapsulação às nanopartículas (\%EE).......................................... 41

4.2.5.4. Avaliação morfológica das nanopartículas...................................................... 42

4.2.5.5. Espectroscopia de infravermelho (FTIR)....................................................... 42

4.2.5.6. Análise Termogravimétrica (TGA)............................................................. 42

4.2.5.7. Perfil de liberação da Curcumina......................................................................... 42

4.2.6. Avaliação da atividade citotóxica in vitro da curcumina livre e nanoencapsulada 43

4.2.6.1. Manutenção das células.............................................................................. 43

4.2.6.2. Contagem Celular...................................................................................... 44

4.2.6.3. Ensaio de viabilidade celular......................................................................... 
4.2.6.4. Controle Positivo......................................................................................... 46

4.2.6.5. Análise estatística............................................................................................. 47

5. RESULTADOS E DISCUSSÃO...................................................................... 48

5.1. Determinação do seu diâmetro hidrodinâmico, PDI e potencial

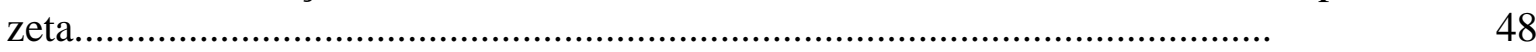

5.2. Avaliação da estabilidade físico-químicas das nanopartículas em suspensão.......... 49

5.3. Eficiência de encapsulação da curcumina às nanopartículas (\%EE)....................... 54

5.4. Avaliação morfológica das nanopartículas............................................................. 55

5.5. Espectroscopia de infravermelho (FTIR) ……………...................................... 56

5.6. Análise Termogravimétrica (TGA)...................................................................... 58

5.7. Perfil de liberação da curcumina.............................................................................. 60

5.8. Avaliação da atividade citotóxica in vitro da curcumina livre e nanoencapsulada.... 64

6. CONSIDERAÇÕES FINAIS................................................................................. 68

7. REFERÊNCIAS BIBLIOGRÁFICAS.................................................................. 


\section{ÍNDICE DE FIGURAS}

Figura 1. Representação esquemática de nanocápsulas e nanoesferas poliméricas; a) ativo dissolvido no núcleo oleoso das nanocápsulas; b) ativo adsorvido à parede polimérica nas nanocápsulas; c) ativo retido na matriz polimérica das nanoesferas; d) ativo adsorvido ou disperso molecularmente na matriz polimérica das nanoesferas........

Figura 2. Estrutura química da Quitina e Quitosana.

Figura 3. Estrutura de unidade repetida do sulfato de condroitina.

Figura 4. (A) Curcuma longa (Zingiberaceae); (B) detalhes das raízes e (C) condimento obtido após secagem e moagem.

Figura 5. Estrutura química da curcumina.

Figura 6. Estrutura molecular dafosfatidilcolina, maior componente da lecitina. 26

Figura 7. Perfil de liberação de fármacos convencional (A) e controlado (B) em função do tempo.

Figura 8. Curva de titulação condutimétrica da quitosana com $\mathrm{NaOH} 0,1$ mol. $\mathrm{L}^{-1}$. 32

Figura 9. Espectro UV-vis da curcumina em $\mathrm{pH} 4,0$ a partir de uma solução 2,71 mmol. $\mathrm{L}^{-1}$.

Figura 10. Curva padrão de calibração da curcumina na solução fosfato $0,1 \mathrm{mo} . \mathrm{L}^{-1} \mathrm{em}$ $\mathrm{pH} 6,8$.

Figura 11. Formação do complexo polieletrolítico.

Figura 12. Diagrama de especiação da superfície da quitosana e do sulfato de condroitina em função do $\mathrm{pH}$.

Figura 13. Preparação de nanopartículas de quitosana / sulfato de condroitina através da técnica de gelatinização iônica..

Figura 14. Preparação de nanopartículas de quitosana / sulfato de condroitina contendo curcumina através da técnica de gelatinização iônica......

Figura 15. Preparação de nanopartículas de quitosana / sulfato de condroitina contendo curcumina e lecitina através da técnica de gelatinização iônica.

Figura 16. Diâmetro hidrodinâmico das Nps de: (a) QTS/SC com e sem lecitina, (b) QTS/SC/Curcumina com e sem lecitina na temperatura de $25^{\circ} \mathrm{C}$ durante o período de 90 dias.

Figura 17. Diâmetro hidrodinâmico das Nps de: (a) QTS/SC com e sem lecitina, (b) 
QTS/SC/Curcumina com e sem lecitina na temperatura de $4^{\circ} \mathrm{C}$ durante o período de 90 dias.

Figura 18. Potencial zeta das Nps de: (a) QTS/SC com e sem lecitina, (b) QTS/SC/Curcumina com e sem lecitina na temperatura de $25^{\circ} \mathrm{C}$ durante o período de 90 dias.

Figura 19. Potencial zeta das Nps de: (a) QTS/SC com e sem lecitina, (b) QTS/SC/Curcumina com e sem lecitina na temperatura de $4^{\circ} \mathrm{C}$ durante o período de 90 dias.

Figura 20. Microscopia Eletrônica de Transmissão para as amostras: A) QTS/SC $(50 \mathrm{~nm}) ; \quad$ B) QTS/SC/Curcumina $\quad(100 \mathrm{~nm}) ; \quad$ C) QTS/SC/Lecitina/Curcumina $(100 \mathrm{~nm})$

Figura 21. Espectros de FTIR para: a)quitosana; b)sulfato de condroitina; c)nanopartícula de QTS/SC; d)nanopartícula de QTS/SC/lecitina; e)nanopartícula de QTS/SC/Curcumina; f)nanopartícula de QTS/SC/Lecitina/Curcumina e g) curcumina.

Figura 22. Análise termogravimétrica para os materiais usados na produção das nanopartículas, nos sistemas puros (A) e nos sistemas contendo lecitina (B)

Figura 23. Liberação controlada de curcumina a partir de Nps de QTS/SC e QTS/SC/lecitina em solução de fosfato em $\mathrm{pH}$ 6,8.

Figura 24. Avaliação da atividade citotóxica in vitro da curcumina livre e encapsulada em Nps de QTS/SC e QTS/SC/Lecitina no período de 24h ( $\mathrm{p}<0.001)$

Figura 25. Avaliação da atividade citotóxica in vitro da curcumina livre e encapsulada em Nps de QTS/SC e QTS/SC/Lecitina no período de 48h (p < 0.001)....

Figura 26. Avaliação da atividade citotóxica in vitro da curcumina livre e encapsulada em Nps de QTS/SC e QTS/SC/Lecitina no período de 72h ( $\mathrm{p}<0.001)$ 


\section{ÍNDICE DE TABELAS}

Tabela 1. Dados referente a curva padrão de calibração $(y=a+b x)$ para determinação da concentração das soluções de curcumina..................................................................... 34

Tabela 2. pKa teóricos da quitosana e sulfato de condroitina........................................... 35

Tabela 3. Diâmetro hidrodinâmico, PDI e potencial zeta das NPs de QTS/SC e QTS/SC/Lecitina padrão e contendo curcumina............................................................ 48

Tabela 4. PDI das NPs de QTS/SC, QTS/SC/LECITINA, QTS/SC/CURCUMINA e QTS/SC/LECTINA/CURCUMINA em função da temperatura, durante o período de 90 dias.

Tabela 5. $\mathrm{pH}$ das NPs de QTS/SC, QTS/SC/LECITINA, QTS/SC/CURCUMINA e QTS/SC/LECTINA/CURCUMINA em função da temperatura, durante o período de 90 dias

Tabela 6. Eficiência de encapsulação da curcumina em Nps de QTS/SC e QTS/SC/lecitina.

Tabela 7. Relação entre o expoente difusional $\boldsymbol{n}$ e o mecanismo de liberação para os diferentes sistemas de liberação controlada

Tabela 8. Dados referente a linearização das curvas de liberação $(y=a+b x)$ para determinação do mecanismo de liberação da curcumina.

Tabela 9. Dados cinéticos e análise do mecanismo de liberação 


\section{ÍNDICE DE EQUAÇÕES}

Equação 1. Determinação do Grau de desacetilação (\%GD) para a quitosana via titulação condutimétrica.

Equação 2. Determinação da eficiência de encapsulação para a curcumina.................... 42

Equação 3. Quantificação da liberação cumulativa da curcumina.................................. 43

Equação 4. Determinação da quantidade de células por volume de suspensão celular... 44

Equação 5. Concentração de células por poço.............................................................. 45

Equação 6. Porcentagem de Células viáveis (\%) obtidas no estudo de MTT.................. 46

Equação 7. Análise do mecanismo de liberação da curcumina a partir de NPs ............. 61 


\section{LISTA DE SIGLAS, SÍMBOLOS E ABREVIATURAS}

AIDS Síndrome da Imunodeficiência Adquirida

DSL Espalhamento de Luz Dinâmico

DNA Ácido desoxirribonucleico

FTIR Infravermelho com transformada de Fourier

GAGs Glicosaminoglicanos

GD Grau de desacetilação

$\mathrm{HCl}$ Ácido Clorídrico

HeLa Henriqueta Lacks - linhagem de células tumorais

Hep3B Linhagem de célula tumoral humana do fígado

MCF-7 Linhagem de célula tumoral humana de mama

MET Microscopia Eletrônica de Transmissão

MEV Microscopia Eletrônica de Varredura

$\mathrm{NaOH} \quad$ Hidróxido de Sódio

$\mathrm{NH}_{2} \quad$ Grupo funcional amino

$\mathrm{NH}_{3} \quad$ Amônia

nm Nanômetros

NPs Nanopartículas

PDI Índice de polidispersão

pH Potencial de hidrogênio

pKa Constante de dissociação ácida

\% TA Porcentagem de Taxa de Associação

\%GD Porcentagem de Grau de desacetilação

QTS Quitosana

RNA Ácido ribonucleico

SC Sulfato de Condroitina

SW620 Linhagem de célula tumoral humana de cólon

UV-vis Ultravioleta na região do visível

$\lambda_{\text {máx }} \quad$ Comprimento de onda máximo de absorção 


\section{INTRODUÇÃ̃}

O estudo em torno da nanotecnologia é recente, tendo seu marco inicial em 1959 quando o físico americano Richard P. Feynman participou do encontro anual da American PHysical Socociety, apresentando uma visão tecnológica de miniaturização extrema e também abordou sobre as dificuldades de se manipular e controlar objetos de pequenas escalas (VELOSO, 2007). Baseado nas ideias de Feynman o objetivo maior da nanotecnologia seria criar novos materiais e desenvolver novos produtos e processos baseados na crescente capacidade de tecnologia moderna em ver e manipular átomos e moléculas (SILVA, 2003).

Cabe ressaltar, que a nanotecnologia não é uma miniaturização, ela se diferencia desta, pois não possui apenas alterações em suas dimensões e também não se parece com nenhuma outra estrutura apresentando propriedades distintas. Sendo assim, a nanotecnologia é definida como o conjunto de ações que envolvem pesquisa, desenvolvimento e inovação relacionadas às propriedades especiais que a matéria exibe quando organizada a partir de estruturas de dimensões nanométricas. (MARTINS apud CARDOSO, 2009). Ela envolve produção e aplicação em sistemas físicos, químicos e biológicos em escalas que variam de um átomo individual a moléculas com cerca de 100 nanômetros, assim como a integração das nanoestruturas resultantes em sistemas mais complexos. Um nanômetro vale $1 \times 10^{9}$ metros e tem como símbolo $\mathrm{nm}$. É uma unidade de comprimento do SI, comumente usada para medição de comprimentos de onda de luz visível (400nm a 700nm), radiação ultravioleta, radiação infravermelha e radiação gama, entre outras.

O desenvolvimento da nanotecnologia apresenta um grande potencial de inovação, uma vez que se aplica a diversos tipos de substâncias, inclusive polímeros (carreador de proteínas e fármacos) e biomateriais (pele, ossos e cartilagens) (SOARES, 2005; SHINDE, 2010). As propriedades físicas e químicas destes materiais são de grande importância para aplicações tecnológicas e o desenvolvimento da nanotecnologia tem demonstrado um campo científico multidisciplinar, encontrando aplicações nas mais diversas áreas, como por exemplo, na medicina, indústria eletrônica e de comunicações, indústria alimentícia, meio ambiente, energia e indústria automobilística e aeronáutica com a utilização de nanopartículas, nanocristais, nanofios, nanotubos, nanofitas e nanocompósitos (FERREIRA et al., 2009; GOMES et al., 2002; GATTI et al., 2002).

Nos últimos anos, um considerável interesse tem sido dado aos materiais nanoestruturados para aplicações em diversas áreas biomédicas, não somente como 
carreadores de fármacos, mas também como biossensores, biomarcadores e imagens moleculares (SAHOO e LABHASETWAR, 2003; EMERICH e THANOS, 2006). Nas áreas farmacêuticas de liberação de fármacos, os principais objetivos dos estudos concentram-se em aumentar o controle da liberação, a especificidade e a seletividade ao local de ação do fármaco, bem como diminuição da dose e de seus efeitos colaterais (BARRATT, 2000).

Diante do exposto, a presente pesquisa tem por objetivo avaliar o efeito da adição da lecitina de gema do ovo nas características de nanopartículas de quitosana e sulfato de condroitina, preparadas pelo método de gelatinização iônica, empregadas na encapsulação da curcumina, bem como avaliar a atividade citotóxica in vitro da curcumina livre e nanoencapsulada, utilizando a linhagem de célula tumoral humana de mama MCF-7. 


\section{REVISÃO BIBLIOGRÁFICA}

\subsection{Nanotecnologia}

Os materiais nanoestruturados são definidos como materiais policristalinos de fase simples ou multifásicos com tamanho de grão na ordem de nanômetros e constituídos principalmente por cristalitos. Devido a estas dimensões extremamente pequenas, os materiais nanoestruturados são estruturalmente caracterizados por uma grande fração volumétrica de contornos de grãos e interfaces, as quais podem alterar uma variedade de propriedades físicas e químicas quando comparados aos materiais cristalinos convencionais. Estas variações resultam do tamanho reduzido, forma dos cristalitos, baixa densidade e/ou número de coordenação entre os elementos estruturais (MACIEL et al., 2003).

A nanotecnologia é uma área de pesquisa e desenvolvimento muito ampla e interdisciplinar, uma vez que se baseia em diferentes tipos de materiais (polímeros, cerâmicas, metais, semicondutores, compósitos, biomateriais, etc), estruturados em escala nanométrica. Os desafios desta área consistem na síntese controlada destas estruturas nanométricas e subsequente arranjo para formar os materiais nanoestruturados para as mais diversas aplicações (DURAN E AZEVEDO, 2002).

\subsection{Nanopartículas poliméricas e a sua produção}

Nanopartículas poliméricas são sistemas carreadores de ativos para os mais diversos fins, que apresentam diâmetro inferior a $1 \mu \mathrm{m}$. É uma expressão coletiva usada para designar tanto nanoesferas quanto nanocápsulas, as quais diferem entre si segundo a composição e organização estrutural, conforme apresentado na Figura 1.
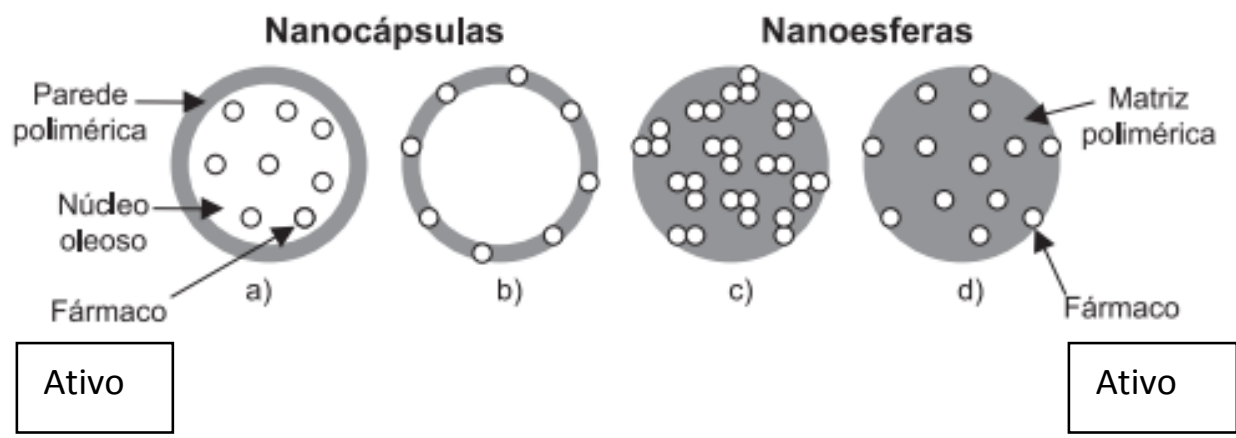

Figura 1 - Representação esquemática de nanocápsulas e nanoesferas poliméricas; a) ativo dissolvido no núcleo oleoso das nanocápsulas; b) ativo adsorvido à parede polimérica nas nanocápsulas; c) ativo retido na matriz polimérica das nanoesferas; d) ativo adsorvido ou disperso molecularmente na matriz polimérica das nanoesferas. Fonte: Adaptada de: SCHAFFAZICK et al., 2003. 
As nanoesferas são formadas por uma matriz polimérica compacta, onde o ativo pode ficar retido ou adsorvido, não apresentando núcleo oleoso em sua composição, já as nanocápsulas são constituídas por um núcleo líquido (geralmente oleoso) envolvido por uma membrana polimérica caracterizando um sistema nanovesicular do tipo reservatório (QUINTANAR-GUERRENO et al., 1998; SCHAFFAZICK et al., 2003). O núcleo (ou cavidade) das nanocápsulas pode conter a substância ativa nas formas líquida ou sólida, como uma dispersão molecular. Essas nanopartículas têm recebido uma atenção especial como sistemas de liberação devido a sua estabilidade e a maior facilidade na modificação de sua superfície (VAUTHIER et al., 2003; HERRERO-VANRELL et al., 2005).

A veiculação do principio ativo no interior de nanocápsulas permite mudar o perfil farmacocinético (absorção, distribuição, metabolismo e excreção) e farmacodinâmico (ação terapêutica) dos compostos encapsulados com consequente melhoria de sua ação, biodisponibilidade e/ou redução de toxicidade (REIS et al., 2006; DE MARTIMPREY et al., 2009).

As matérias-primas, utilizadas na produção das nanopartículas, podem interferir nas suas características, dentre elas o diâmetro da partícula, morfologia, potencial zeta, eficiência de encapsulação e/ou associação e liberação da substância ativa, que impõe sua resistência físico-química e biológica (SANTOS, 2010; LEGRAND et al., 2007; DASHA et al., 2011; SUNDAR et al, 2010).

Existem diversos métodos na literatura para a preparação de nanopartículas poliméricas, os quais podem ser geralmente classificados em: i) métodos baseados na polimerização in situ de monômeros dispersos (incluem a polimerização em emulsão, polimerização interfacial e a policondensação interfacial); ii) na precipitação de polímeros pré-formados e; iii) na gelatinização iônica. A incorporação do fármaco pode ser feita durante a produção das nanopartículas ou após a sua formação, pela adição de uma solução concentrada de fármaco (SCHAFFAZICK et al., 2003; MOHANRAJ et al., 2006; REIS et al., 2006; RODRIGUEZ et al., 2004).

Os métodos de preparação de nanopartículas a partir de polímeros pré-formados são particularmente adaptados para incorporar princípios ativos lipofílicos (SEVERINO et al., 2011). As nanopartículas devem ser preparadas com base numa razão princípio ativo/polímero adequada à obtenção de uma eficiência de encapsulação elevada e baixa toxicidade. Em regra, a escolha de um método de preparação é determinada pelas características de solubilidade do princípio ativo (SILVA, 2010). Em comparação com os métodos de produção de nanopartículas poliméricas a partir da polimerização de monômeros, 
a preparação utilizando polímeros pré-formados é mais facilmente controlável, de maior rendimento, e pode ser realizada por emulsificação-evaporação do solvente (WANG, 2010), por deslocamento do solvente (TAHARA et al., 2010), por salting-out ( WHEATLEY \& LEWANDOWSKI, 2010) ou por emulsificação-difusão do solvente (OZTURK, 2010). Estes métodos empregam polímeros previamente formados, ocorrendo dissolução e precipitação do polímero na formulação de preparo das nanopartículas. A baixa taxa de encapsulação de substâncias hidrossolúveis é uma característica semelhante entre esses métodos e é preferencialmente empregada para substâncias lipossolúveis. Além disso, esses métodos necessitam de equipamentos caros e sofisticados, o que dificulta o preparo das nanopartículas (GUTERRES et al., 2007; SCHAFFAZICK et al., 2003; REIS et al., 2006; SANTOS, 2010; SOPPIMATH et al., 2001).

Outro método empregado na preparação de nanopartículas poliméricas é o de gelatinização iônica. Este tem despertado grande interesse dos pesquisadores em relação aos outros métodos, pois é caracterizado como um processo simples e que não necessita de equipamentos caros e sofisticados. Neste método ocorre uma espécie de reticulação física, reversível por meio de interações eletrostáticas entre o polímero e o gelatinizador iônico (DASHA et al., 2011; TAGLIARI et al., 2012). Neste estudo utilizaremos a técnica de gelatinização iônica no desenvolvimento de nanopartículas de quitosana e sulfato de condroitina.

\subsection{Biopolímeros}

Biopolímeros são polissacarídeos de origem microbiana, também conhecidos como gomas ou expolissacarídeos (EPS), que têm a capacidade de formar géis e soluções viscosas em meio aquoso (MOREIRA et al., 2003). Apresentam-se como uma alternativa às gomas tradicionais, com um visível interesse por suas propriedades reológicas, sendo utilizados amplamente como espessantes, gelificantes e estabilizantes nas indústrias de alimentos, farmacêutica, química e petroquímica (PACE, 1991; MAUGERI, 2001).

\subsubsection{Quitosana}

A quitosana (QTS) (Figura 2) é um biopolímero natural, abundante e atóxico, obtido pela desacetilação da quitina. A Quitina é um dos polímeros produzidos em maior quantidade na natureza, sendo muito encontrado em ecossistemas aquáticos. Sua produção anual na 
crosta terrestre, incluindo ecossistemas aquáticos, é estimada em 2,2 bilhões de toneladas (SYNOWIECKI, 2003). Tem funções estruturais em artrópodes, sobretudo em crustáceos, sendo encontrada, por exemplo, na casca do camarão e na carapaça de caranguejos associada a materiais inorgânicos (principalmente carbonato de cálcio) e a proteínas, além de alguns corantes (RINAUDO, 2006; ROBERTS, 1992). É composto pelas unidades monoméricas de

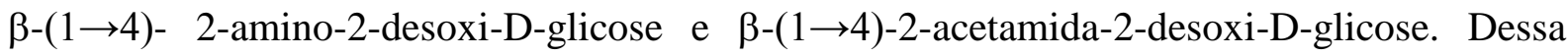
forma, é um polímero insolúvel em meio aquoso e na maioria dos solventes inorgânicos, e tem baixa reatividade química (LARANJEIRA, et al., 2009).

O grau de desacetilação (GD) é capaz de influenciar as características químicas, físicas e biológicas do bipolímero, uma vez que este expressa a porcentagem média de resíduos acetilados presentes na cadeia do biopolímero. O processo de desacetilação da quitina, método mais comum de obtenção da quitosana, consiste na reação de hidrólise básica da quitina com solução de $\mathrm{NaOH}$. Assim a quitosana é um polissacarídeo composto por unidades D-glucosamina e N-acetil-D-glucosamina unidas por ligações $\beta$ - $(1 \rightarrow 4)$.

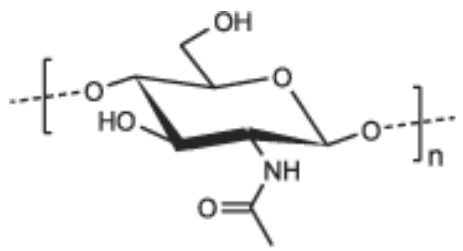

quitina

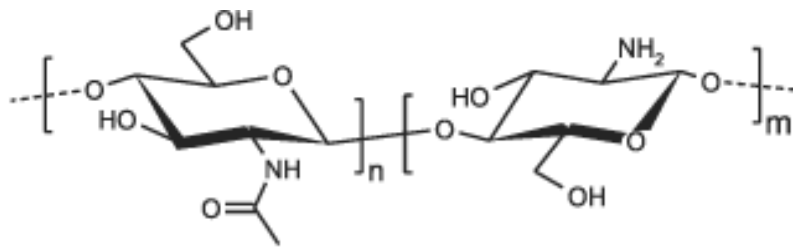

quitosana

Figura 2 - Estrutura química da Quitina e Quitosana. Fonte: SILVA et al., 2006.

Com propriedades biológicas que incluem biocompatibilidade, biodegradabilidade em produtos inofensivos, não tóxicos, fisiologicamente inertes, afinidade notável a proteínas, e propriedades hemostática, fungistática, antitumoral, anticolesterol, a quitina e a quitosana, oferecem um potencial extraordinário numa larga faixa de aplicações que tendem a crescer rapidamente uma vez que os materiais quitinosos padronizados tornam-se disponíveis. De maneira importante, como biopolímeros e materiais biodegradáveis a quitina/quitosana são seguros para os seres humanos e para o ambiente natural (KUMAR et al., 2004; DALLAN, 2005; DENG, 2007).

A presença de uma alta porcentagem de grupos amino reativos distribuídos na matriz polimérica permite inúmeras modificações químicas, tais como imobilização de agentes 
quelantes, quartenização, carboxilação, acilação, sulfonação, amidação, formação de complexo polieletrolítico entre outros (RODRIGUES et al., 1998; COELHO et al., 2008).

A QTS possui grupos amino e hidroxila reativos capazes de serem submetidos a modificações químicas. Adicionalmente, os grupos amino tornam a quitosana um dos únicos polieletrólitos catiônicos achados na natureza (pKa 6,5), esta condição confere propriedades singulares a quitosana. A QTS é solúvel em meios aquosos ácidos de $\mathrm{pH}<6,5$ e quando dissolvida possui alta carga positiva sobre os grupos $-\mathrm{NH}^{+}$. Adere a superfícies carregadas negativamente, agrega-se com compostos polianiônicos, e tem a capacidade de ligar-se a íons metálicos (KUMAR et al., 2004).

As aplicações de quitosana na indústria e na pesquisa cientifica são amplas, desde cosméticos e alimentos até a complexação de metais e corantes, interação com surfactantes e polímeros, embalagens, entre outras (RINAUDO, 2006; GOOSEN 1997; KUMAR, 2000). Outro ramo importante de pesquisa e aplicação refere-se ao uso do polímero como matriz sólida para imobilização de enzimas. Nesses casos objetiva-se a fabricação de nanoestruturas para dispositivos óticos, eletrônicos e principalmente sensores de reconhecimento de biomoléculas (SIQUEIRA et al, 2006).

O uso de quitosana como veículo para liberação controlada de drogas se baseia em três das principais propriedades do polímero: biocompatibilidade, biodegradabilidade e mucoadesividade. A quitosana é processada em várias formas como filmes, membranas, géis, nanopartículas, microesferas e fibras, e princípios ativos dos fármacos são incorporados a essas estruturas (KUMAR et al, 2004). A mucoadesão, que é a capacidade de o material aderir ao tecido de revestimento de cavidades internas do corpo humano, permite aplicabilidade dos fármacos em sítios bastante localizados, somente onde deve agir. Essa é uma propriedade que reflete a estabilidade da interação do material com tecidos e células, sendo bastante influenciada pela interação do material com o muco. No caso da quitosana, a mucoadesão é atribuída principalmente à forte interação com a proteína mucina, principal componente do muco, através de ligações eletrostáticas, mas também influenciada por ligações de hidrogênio e ligações hidrofóbicas (SOGIAS et al., 2008). As outras duas características, biocompatibilidade e biodegradabilidade, permitem, respectivamente, que não ocorra rejeição por parte do corpo à matriz, e que após a ação do medicamento a mesma seja eliminada.

As nanopartículas formadas à base de quitosana, geralmente apresentam uma distribuição unimodal, com baixo índice de polidispersão, bem como um potencial de superfície positivo, o que facilita a interação com as membranas biológicas. No entanto, dependendo do método de preparação empregado é possível observar diferenças no tamanho, 
morfologia e potencial zeta das nanopartículas formadas. (DASHA et al., 2011; SCHAFFAZICK et al., 2003).

\subsubsection{Sulfato de Condroitina}

É um biopolímero natural solúvel em água altamente purificado de cadeias repetidas de moléculas denominadas mucopolissacarídeos, encontrado nas cartilagens da maioria dos mamíferos como bovina, porcina e do homem. Caracteriza-se por se ruma glicosaminoglicano monossulfatado de cadeia longa, variando seu comprimento médio de um tecido para outro ou dentro do mesmo tecido. Em geral, a massa molecular média das cadeias de SC diminui com a idade, estresse ou dano na cartilagem articular (RICHY et al., 2003; TOFFOLETT et al., 2005; LOPES,2009).

O SC é caracterizado quimicamente como um heteropolímero aniônico linear de ácido D-glucurônico e N-acetil-D-galactosamina. O primeiro a descrever o SC foi Levene em 1925, ele mostrou que seus constituintes eram o ácido glucorônico, D-galactosamina e ácido acético e sulfúrico (ROSEMANN, 2001; SANTOS, 2009). Entretanto, a sua correta estrutura foi elucidada mais tarde: composto por unidades repetidas de $\beta(1,4)$-D-ácido glucorônico e $\beta(1,3)$ - N-acetil-D-galactosamina, também ficou elucidado que nos mamíferos, a posição mais comum do radical sulfato (que determina qual isômero é formado) é o C4 e/ou C6 da Nacetil-D-galactosamina, formando condroitina-4-sulfato e a condroitina-6-sulfato, respectivamente. A Figura 3 é apresentada a estrutura da unidade repetida do sulfato de condroitina.

A

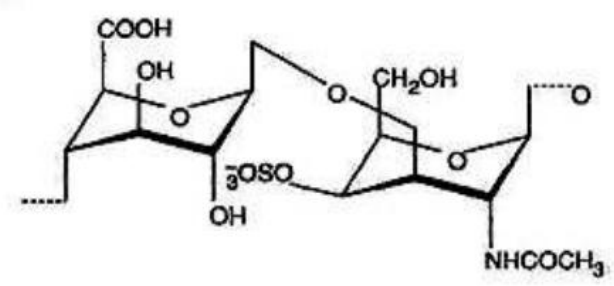

B

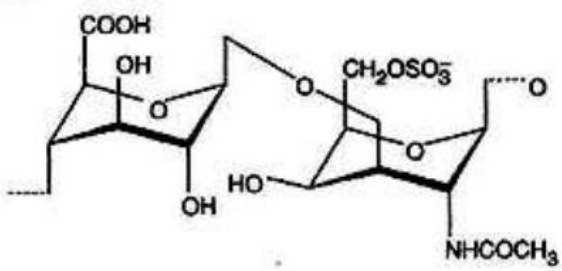

C

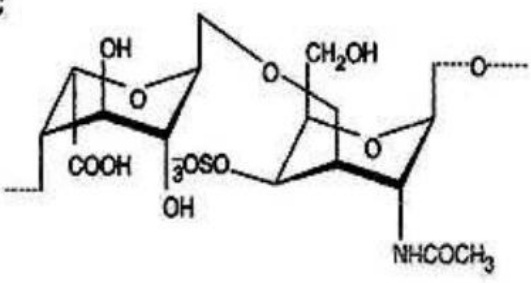

Figura 3 - Estrutura química do sulfato de condroitina. Fonte: Adaptado de PAVÃO, et al 2006. 
Estudos mostram que o sulfato de condroitina apresenta propriedades antiinflamatórias in vivo e que consegue regular in vitro o metabolismo dos condrócitos, como o estímulo à síntese de proteoglicanos e colágeno e a inibição de citocinas envolvidas na degradação da cartilagem (PENICHE et al., 2007). Os GAGs também podem sequestrar proteínas e levá-las aos sítios apropriados para ativação. Essa função permite que eles sejam capazes de influenciar a adesão, migração, proliferação e diferenciação das células (CHEN et al., 2006).

\subsection{Curcumina}

Cúrcuma é um tempero indiano derivado do rizoma da planta Curcuma longa Linn (Figura 4) que tem sido utilizada na medicina Ayurvédica para tratar infecções oculares, feridas, picadas de cobra, queimadura e acne. A Curcuma longa pertence à família Zingiberaceae e é amplamente cultivada na Índia e em outras partes do sudeste asiático, é conhecida popularmente como açafrão. O principal constituinte ativo da cúrcuma e um dos responsáveis por sua cor amarela vibrante é a curcumina (HATCHER et al., 2008).

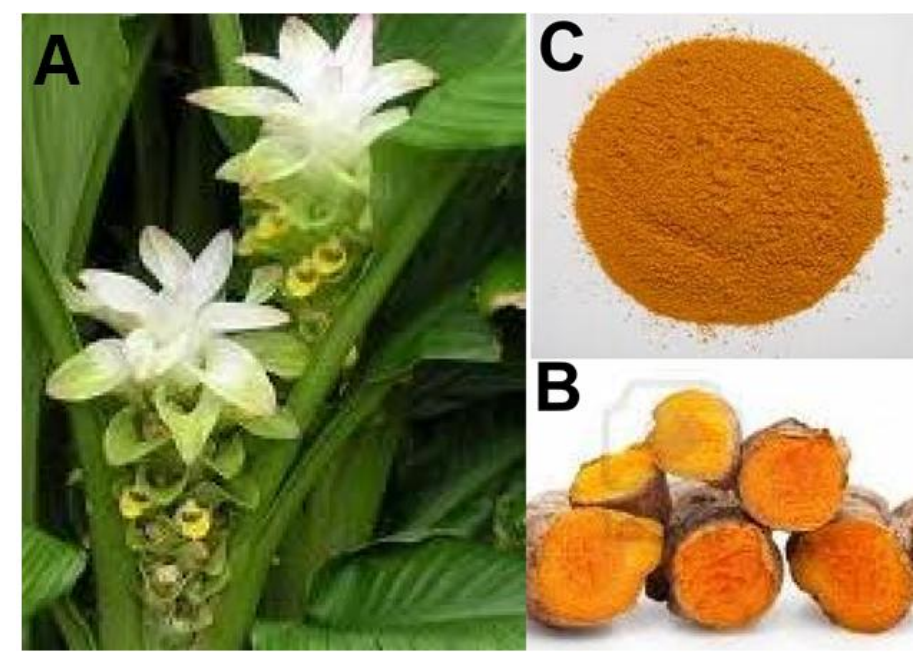

Figura 4 - (A) Curcuma longa (Zingiberaceae); (B) detalhes das raízes e (C) condimento obtido após secagem e moagem. Fonte: Adaptado de HAMERSKI et al., 2013.

A curcumina ou diferuloilmetano (1,7-bis(4-hidroxi-3-metoxifenil)-1,6- heptadieno3,5-diona) apresenta natureza polifenólica (CHEN \& HUANG, 1998), seu peso molecular é de $368,4 \mathrm{~g} / \mathrm{mol}$ e fórmula molecular $\mathrm{C}_{21} \mathrm{H}_{20} \mathrm{O}_{6}$. Apresenta solubilidade em etanol, acetona e dimetilsulfóxido (DMSO), sendo pouco solúvel em água (TONNESEN \& KARLSEN, 1985).

A curcumina, demetoxicurcumina e bisdemetoxicurcumina apresentam absorções máximas no espectro do ultra violeta, nos comprimentos de onda de 429, 424 e $419 \mathrm{~nm}$. Os 
pigmentos curcuminóides apresentam fluorescência amarela sob luz ultravioleta. O espectro de fluorescência apresenta excitação a 434 nm e emissão a 520 nm (SOUZA, 1993; PÉRETALMEIDA et al., 2003).

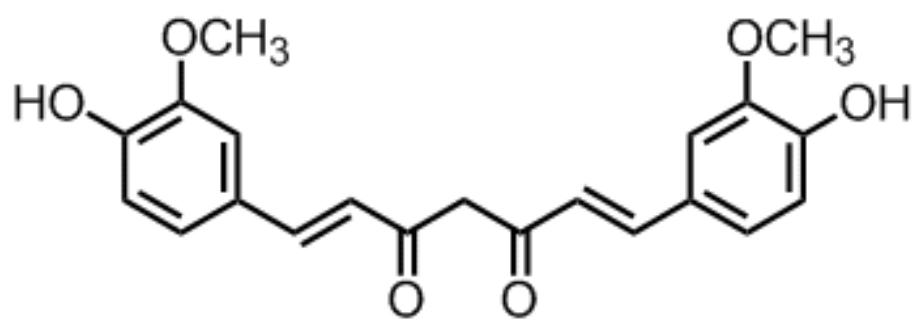

\section{curcumina}

Figura 5 - Estrutura química da curcumina. Fonte: HATCHER et al. 2008

Estruturalmente a curcumina exibe um tautomerismo ceto-enólico, como predominância da forma ceto em $\mathrm{pH}$ de 3 a 7 , possuindo uma estrutura $\beta$-dicetona, atuando como potente doador de prótons. Em pH acima de 8 a forma enólica da curcumina predomina, atuando como doador de elétrons, assim como a maioria dos antioxidantes fenólicos (ANAND et al., 2008; SHARMA et al., 2005). É praticamente insolúvel em água, mas solúvel em etanol, acetona, dimetilsulfóxido e outros solventes orgânicos (SHARMA; GESCHER; STEWARD, 2005).

A curcumina é estável em pH ácido, mas é instável e sofre rápida degradação hidrolítica em condições neutras ou alcalinas. A estabilidade da curcumina tem sido investigada por vários autores (WANG et al., 1997; TONNESEN, 2002; TONNESEN; MASSON; PFEIFFER et al., 2003; ANSARI et al., 2005; TOMREN et al., 2007; ZEBIB; MOULOUNGUI; NOIROT, 2010). Estudos in vitro têm demonstrado que mais de $90 \%$ da curcumina é rapidamente degradada em condições fisiológicas (tampão fosfato, $\mathrm{pH}$ 7,2 a $\left.37^{\circ} \mathrm{C}\right)$.

Este fenólico tem sido reconhecido como um antioxidante natural com atividade antitumoral e antimutagênica, inibidor do metabolismo do ácido araquidônio, capaz de induzir apoptose e alterar a expressão gênica, inibir a atividade de importantes fatores de transcrição como NFкB e AP-1, e é um eficiente agente antiinflamatório. Atualmente está sendo avaliado como um possível agente quimiopreventivo pelo Instituto Nacional do Câncer nos Estados Unidos (KIM, 2001; SINGH; KHAR, 2006). 
Pesquisas demonstraram o potencial antitumoral da curcumina em estudo in vitro e in vivo, em que ela foi capaz de inibir o crescimento de várias linhagens de células cancerosas. A curcumina exerce efeitos citotóxicos em linhagens tumorais como a MCF-7 (câncer de mama), Hep3B (hepatocarcinoma), HeLa (carcinoma cervical) e SW620 (câncer de colón) (NING et al., 2009). Estes estudos indicam o potencial terapêutico da curcumina nos cânceres do cérebro, mama, trato gastrointestinal, cabeça e pescoço, fígado, pâncreas, cólon, próstata e ovário (ANAND et al., 2008 KUNNUMAKKARA; ANAND; AGGARWAL, 2002).

\subsection{Surfactantes}

Um surfactante é um composto caracterizado pela capacidade de alterar as propriedades superficiais e interfaciais de um líquido, reduzindo a tensão e a energia livre superficiais. Os surfactantes são aplicados industrialmente em diversas áreas como: detergência, emulsificação, capacidade espumante, capacidade molhante, solubilização e dispersão de fases (MARCELINO et al., 2007). A maioria dos surfactantes comercialmente utilizada é obtida através de derivados do petróleo.

Também existem os "surfactantes naturais", presentes em algumas plantas (saponinas), microorganismos (glicolipídeos, lipolipídeos), animais (sais biliares) e alguns carboidratos (REIS, 2007).

Os surfactantes convencionais são moléculas anfifílicas, pois possuem uma cabeça polar hidrofílica e uma ou duas cadeias alquilas que são hidrofóbicas (SOLERLLIA et al., 2002). Os surfactantes do tipo bola-anfifílicos são moléculas que possuem uma cabeça polar em cada extremidade da cadeia hidrofóbica, o que os torna mais solúveis em água. Os surfactantes do tipo gemini, possuem duas cadeias alquilas ligadas cada uma a uma cabeça polar. Essas cabeças polares podem ser interligadas por um espaçador rígido. Possuem boa solubilidade em solventes orgânicos (WAN e ZHAO, 2007).

De acordo com a carga da cabeça polar da molécula, os surfactantes podem ser classificados em iônicos e não iônicos. Os surfactantes iônicos são aqueles que quando se dissociam em solução aquosa liberam o seu contra-íon. A dissociação do surfactante expõe uma carga na parte polar do surfactante, que pode ser positiva ou negativa, classificando-os em catiônicos e aniônicos, respectivamente (WAN e ZHAO, 2007). 


\subsubsection{Lecitina}

A lecitina age como um importante surfactante a qual desempenha a função de estabilizar a formação da nanopartícula, diminuindo a pressão e evitando a coalescência da mesma, promovendo também um aumento da solubilidade do ativo na nanopartícula formada (ROMIO et. al, 2007).

É uma mistura complexa de fosfolipídios, triglicérides e outras substâncias derivadas de vários processos de refinamento do óleo de soja. Devido à sua disponibilidade abundante e excelentes propriedades, incluindo sua ação emulsificante, cor e sabor, torna-se um importante aditivo industrial (NASIR; BERNARDS; CHARPENTIER, 2007). Embora a palavra lecitina seja derivada do grego "lekithos", que significa "gema de ovo", a principal fonte comercial de lecitina vem da soja.

Os fosfolipídios, principalmente a fosfatidilcolina, fosfatidiletilenoamina, fosfatidilinositol e ácido fosfatídico são os principais componentes da lecitina de soja bruta (Figura 6). É possível encontrar muitas aplicações dos fosfolipídios nas indústrias farmacêutica, cosmética e alimentar como um efetivo emulsificante biocompatível, estabilizante, biossurfactante e antioxidante (NASIR; BERNARDS; CHARPENTIER, 2007).

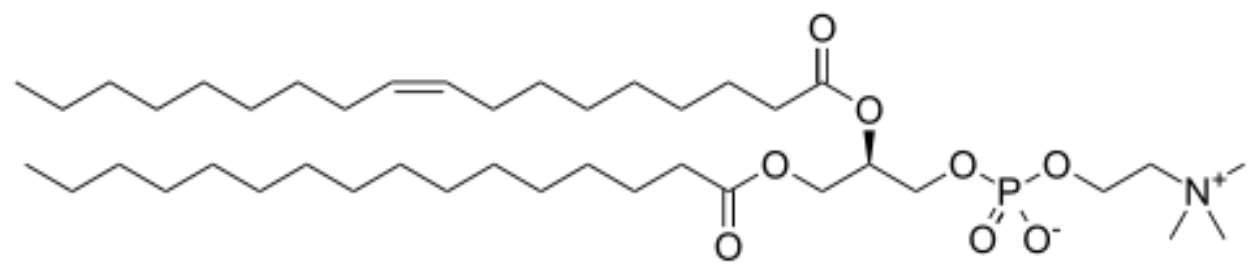

Figura 6: Estrutura molecular da fosfatidilcolina, maior componente da lecitina. Fonte: Adaptado de MACHADO FILHO et al., 2005.

A lecitina tem sido frequentemente utilizada para a preparação de vários nano sistemas de liberação controlada, tais como micro e nanoemulsões (KELMANN et al, 2007 ), lipossomas (PAVELIC et al, 2005), micelas (CERAULO et al. , 2008) e nanopartículas lipídicas sólidas (SCHUBERT et al., 2006).

A lecitina de soja possui uma fração de lipoproteína de baixa densidade, assim como a da gema de ovo, com a função de proteger a integridade da membrana fosfolipídica durante a criopreservação (FOROUZANFAR et al., 2010), e, por ser de origem vegetal, proporciona diversas vantagens, entre elas a padronização dos componentes e a eliminação dos riscos de contaminação (FUKUI et al., 2008). 
Atualmente a interação da lecitina com polímeros positivamente carregados gera a formação de nanopartículas. A partir de uma solução alcoólica de lecitina adicionada a uma solução de quitosana, gera-se um sistema nanoestruturado ao invés de ocorrer a formação de lipossomos. O lipídio negativamente carregado na porção polar (grupo fosfato) interage com a quitosana (grupo $\mathrm{NH}_{3}^{+}$) levando a formação preliminar de uma vesícula. A auto associação do fosfolipídio com o polímero deixam as cadeias polares dos ácidos graxos disponíveis a interação com sistemas hidrofóbicos, tornando o sistema um potencial candidato a incorporação de fármacos hidrofóbicos (TANER, et al., 2014).

\subsection{Liberação controlada de fármacos}

A indústria farmacêutica, fazendo uso das inovações tecnológicas utiliza a nanotecnologia e os nanomateriais para desenvolver fármacos que apresentem a liberação do fármaco de maneira modulada (AZEVEDO, 2002).

Formulações em que o fármaco apresenta liberação controlada é toda aquela que têm como objetivo fornecer uma dose terapêutica de uma droga para um local do corpo predeterminado, e manter esta concentração desejada (GENNARO, 2004), de modo controlado em velocidade e tempo apropriado, buscando também manter os níveis sanguíneos terapêuticos ótimos (ALLEN JR.; ANSEL; POPOVICH 2007) e evitar, a níveis plasmáticos, a problemática da toxicidade e/ou doses tóxicas (AZEVEDO 2002). Desta forma, esse sistema permite que o fármaco seja liberado gradativamente, a uma razão regulada pelas necessidades do corpo, por um período específico de tratamento (GENNARO, 2004).

A manutenção da dose efetiva do fármaco nos locais de ação, associada a uma farmacodinâmica adequada da molécula, promove o sucesso das terapias medicamentosas. Tal estratégia, comumente chamada de sistemas de liberação controlada de fármaco, requer uma ampla interdisciplinaridade, envolvendo conhecimentos principalmente das áreas de ciências farmacêuticas, ciência de polímeros, química de colóides, físico-química e biologia molecular (KAPARISSIDES et al., 2006).

A Figura 7 ilustra a comparação entre o sistema de liberação convencional e o de liberação controlada. 


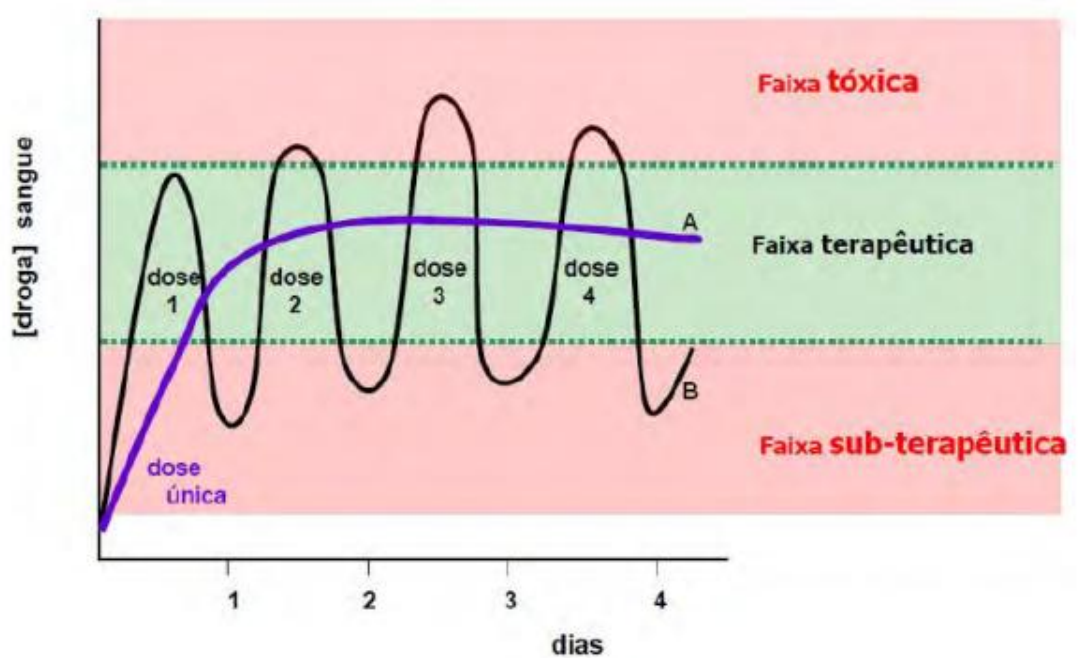

Figura 7 -Curvas do perfil de liberação de fármacos convencional (A) e controlado (B) em função do tempo. Fonte: BOTASSIO; SILVA, 2010.

Os fármacos de liberação convencional são delineados para liberar rapidamente a dose total de fármaco presente, logo após ter sido administrado. Além disso, presume-se que o fármaco liberado está na forma terapeuticamente ativa e disponível imediatamente para a absorção na circulação sistêmica (AULTON, 2005). Diante disso, os sistemas de liberação controlada apresentam grandes vantagens sobre os métodos convencionais, como a menor flutuação dos níveis plasmáticos do fármaco, redução da frequência de administração, maior conveniência e adesão, redução dos efeitos colaterais e redução dos custos globais com a saúde (ALLEN JR; POPOVICH; ANSEL, 2006).

Nanopartículas possuem as características necessárias para que esses sistemas de liberação de fármacos controlados sejam efetivos. Permitem que sejam liberados em local apropriado, tem suas concentrações mantidas em níveis adequados por longos períodos de tempo, além de prevenir sua degradação.Permitem ainda maior eficiência de encapsulação e liberação controlada se comparadas aos sistemas de encapsulação convencionais, além de possuírem tamanho pequeno suficiente para serem injetadas diretamente no sistema circulatório e oferecerem a possibilidade de administração por outras vias como pulmonar, nasal, transcutânea e oral (ALVES; MARTINS; SANTANA, 2008).

Uma alternativa promissora aos sistemas de liberação de fármacos é o desenvolvimento de nanopartículas poliméricas, já que estas aumentam a biodisponibilidade. Essa característica está relacionada a capacidade que estas possuem de proteger de forma eficaz, o fármaco, e simultaneamente aumentarem a sua retenção ou adsorção (SCHAFFAZICK et al., 2003; ZHANG et al., 2006; DES RIEUZ et al., 2006; MOURA, 2012). 
Vários sistemas de liberação são usados, entre eles as nanopartículas. Embora tenham sido desenvolvidos muitos tipos de nanopartículas com a intenção de liberar medicamentos controladamente, somente nos últimos 4 anos foram produzidas nanopartículas com características promissoras, tais como, estabilidade no organismo, segurança, toxicidade e perfil de liberação adequados. As nanopartículas possuem um elevado potencial enquanto veículo de transporte de agentes citotóxicos, pois são capazes de circular pela corrente sanguínea sem escapar das paredes dos respectivos vasos. Em tumores sólidos, as nanopartículas penetram facilmente o interior das células tumorais, liberando o fármaco e evitando a destruição de tecidos saudáveis. (ZHANG et al., 2006; DES RIEUZ et al., 2006; MOURA, 2012).

Os polímeros naturais, incluindo biopolímeros como a quitosana e sulfato de condroitina, têm sido estudados e aplicados nos sistemas de liberação de fármacos, apresentando vantagens em relação aos materiais sintéticos, pelo fato de sua degradação ser controlada pelas células de acordo com os mecanismos fisiológicos (FAJARDO, 2009). Além disso, a utilização desses biopolímeros pode minimizar reações teciduais, promover benefícios terapêuticos e, ao mesmo tempo, diminuir efeitos colaterais. 


\section{Objetivos}

\subsection{Objetivo Geral}

O objetivo desse estudo consistiu em avaliar o efeito da adição da lecitina nas características de nanopartículas de quitosana e sulfato de condroitina, preparadas pelo método de gelatinização iônica, empregadas na encapsulação da curcumina, bem como avaliar a atividade citotóxica in vitro da curcumina livre e nanoencapsulada, utilizando a linhagem de célula tumoral humana de mama MCF-7.

\subsection{Objetivos Específicos}

- Avaliar via diagrama de especiação as melhores condições de $\mathrm{pH}$ para a obtenção de nanoparticulas de quitosana e sulfato de condroitina;

- Caracterização físico-química das nanopartículas obtidas: diâmetro heterodinâmico, polidispersão, potencial zeta, estabilidade das suspensões coloidais, espectroscopia no infravermelho e analise termogravimétrica;

- Avaliação da morfologia das nanopartículas via microscopia eletrônica de transmissão $(\mathrm{MET})$;

- Estudo da liberação controlada da curcumina em solução físiológica $\mathrm{pH}=6,8$, assim como avaliar o mecanismo de liberação do ativo a partir das nanopartículas de QTS/SC;

- Avaliação do potencial citotóxico in vitro da curcumina livre e encapsulada em NPs de QTS/SC e QTS/SC/Lecitina, utilizando uma linhagem de célula tumoral humana de mama MCF-7. 


\section{MATERIAIS E MÉTODOS}

\subsection{Materiais}

Quitosana (99\% de pureza (massa molecular médio) - Sigma Aldrich com massa molecular de $190000 \mathrm{~g} \mathrm{~mol}^{-1}$, fornecido pelo representante e determinado por meio do método viscosimétrico. O Sulfato de condroitina Tipo A, (sal de sódio) (99\% de pureza), foi obtido a partir da traquéia bovina - Sigma Aldrich. A Curcumina (95\% de pureza) foi obtida da Curcuma Longa L. (cúrcuma), - Sigma Aldrich. A lecitina de gema de ovo (60\% de L- $\alpha$ Fosfatidilcolina - Sigma Aldrich. O meio de cultura utilizado foi o RPMI 1640 (R6504, Sigma-Aldrich), o brometo de 3-(4,5-dimetil-2-tiazolil)-2,5-difenil-2H-tetrazolium (MTT) foi fornecido pela Life Technologies (USA) e, a linhagem de célula tumoral humana de mama (MCF-7) foi obtida do banco de células do Rio de Janeiro (BCRJ). Os demais reagente são de grau analítico e foram utilizados sem nenhuma purificação prévia.

\subsection{Métodos}

\subsubsection{Determinação do grau de desacetilação da quitosana (\%GD)}

O grau de desacetilação (\%GD) foi utilizado para determinar a porcentagem de grupos amino $\left(\mathrm{NH}_{2}\right)$ livres na quitosana, via titulação condutimétrica, utilizando-se o método Broussignac (BROUSSIGNAC, 1970) através da metodologia adaptada por ALVARENGA, 2011. Foram dissolvidos $200 \mathrm{mg}$ de quitosana em $40 \mathrm{~mL}$ de $\mathrm{HCl}$ 0,054 mol. $\mathrm{L}^{-1}$ e diluídos com $50 \mathrm{~mL}$ de água destilada para uma boa dispersão do polímero em solução. A solução final foi titulada com solução $\mathrm{NaOH}$ 0,165 mol. $\mathrm{L}^{-1}$. Conduziu-se a titulação até o volume final de 25 $\mathrm{mL}$ de $\mathrm{NaOH}$, com adições de $0,5 \mathrm{~mL}$ de titulante. A titulação condutimétrica foi realizada em triplicata.

A titulação condutimétrica o método escolhido em função da sua precisão e simplicidade, neste estudo. A curva dos valores de condutância, $\mathrm{k}$, versus volume de titulante apresenta dois pontos de inflexão (Figura 8). 


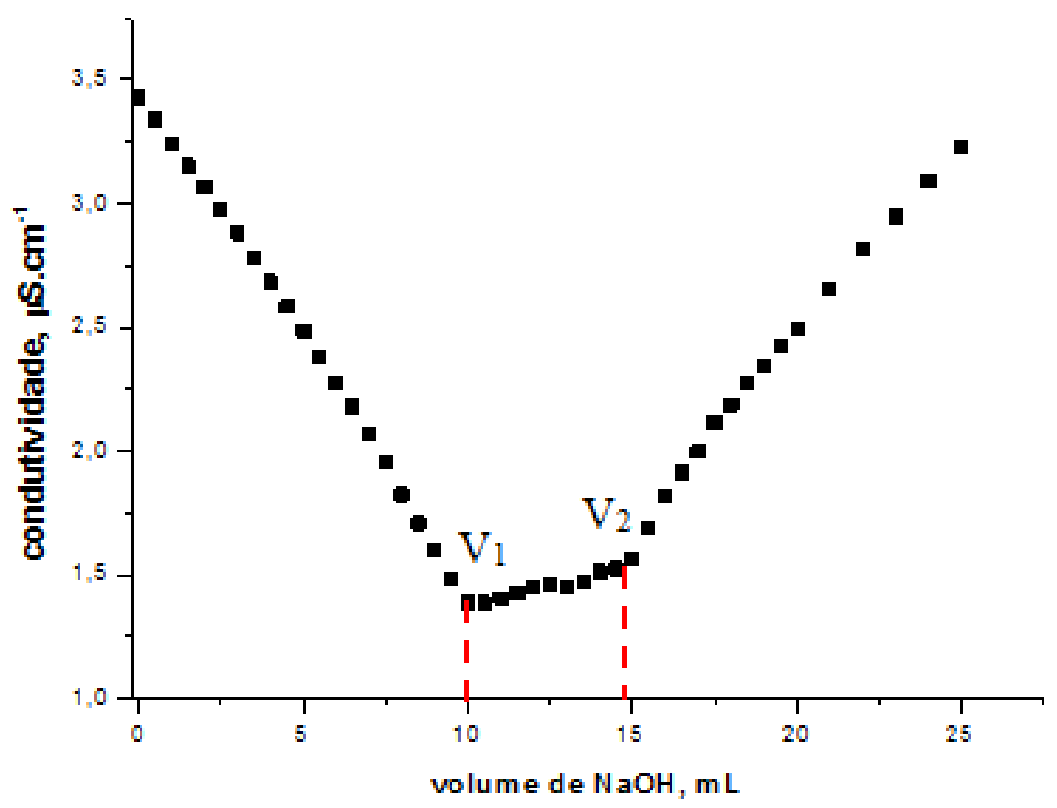

Figura 8 - Curva de titulação condutimétrica da quitosana com $\mathrm{NaOH} 0,1$ mol.L ${ }^{-1}$. Fonte: Autoria própria.

A curva de titulação apresenta dois pontos de inflexão, sendo o primeiro correspondente a neutralização do $\mathrm{HCl}$ em excesso na solução e o segundo referente à neutralização do polímero protonado. A diferença entre os dois pontos de equivalência corresponde ao volume de base requerido para neutralizar os grupos amino. A porcentagem de grupos amino foi calculada de acordo com a equação 6:

$$
\% G D=\frac{M\left(V_{2}-V_{1}\right) 161}{W} \times 100
$$

Onde $\mathrm{M}$ é a concentração da solução de $\mathrm{NaOH}, \mathrm{V}_{1}(9,84 \mathrm{~mL})$ e $\mathrm{V}_{2}(15,63 \mathrm{~mL})$ são os volumes de $\mathrm{NaOH}$ em $\mathrm{mL}$, empregados para neutralizar o excesso de ácido clorídrico e a quitosana protonada, 161 é a massa de uma unidade monomérica do polímero e $\mathrm{W}$ é a massa de amostra em miligramas empregada na titulação. O grau de desacetilação calculado por este método foi de $76,9 \%$, sendo que este valor representa a média de três determinações e mostra que ocorreu a conversão das unidades $N$-acetilglicosamina em grupos amina.

Segundo (TAN, 1996), é o grau de desacetilação que determina se o polímero é quitina ou quitosana, arbitrariamente, o grau de desacetilação $\geq 50$ define o material polimérico como quitosana. 


\subsubsection{Espectroscopia de absorção molecular UV-Vis para a curcumina}

Os espectros de UV-vis para a curcumina foram realizados em um espectrofotômetro UV-VIS-NIR Cary 5000 da Varian, a partir de uma solução de curcumina 0,02 mmol L-1, preparada em solução de fosfato de sódio em pH 6,8 e etanol na proporção 80:20 (tampão:etanol). A análise foi conduzida na faixa de 350 a 750nm (Figura 9).

A partir da curva obtida via espectroscopia UV-Vis, determina-se o $\lambda$ máx para a curcumina em $429 \mathrm{~nm}$. Com base nos valores de pKa da curcumina (pKa1 = 8,3 (equilíbrio cetenólico), $\mathrm{pKa} 2=9,8$ e pKa3 = 10,5 (referentes aos $\mathrm{OH}$ fenólicos), percebe-se que em toda a faixa de compreendida até $\mathrm{pH} 7,5$, a estrutura apresenta-se sem qualquer mudança e o $\lambda$ max está localizado em 429 nm. (BERNABÉ, et al., 2004).

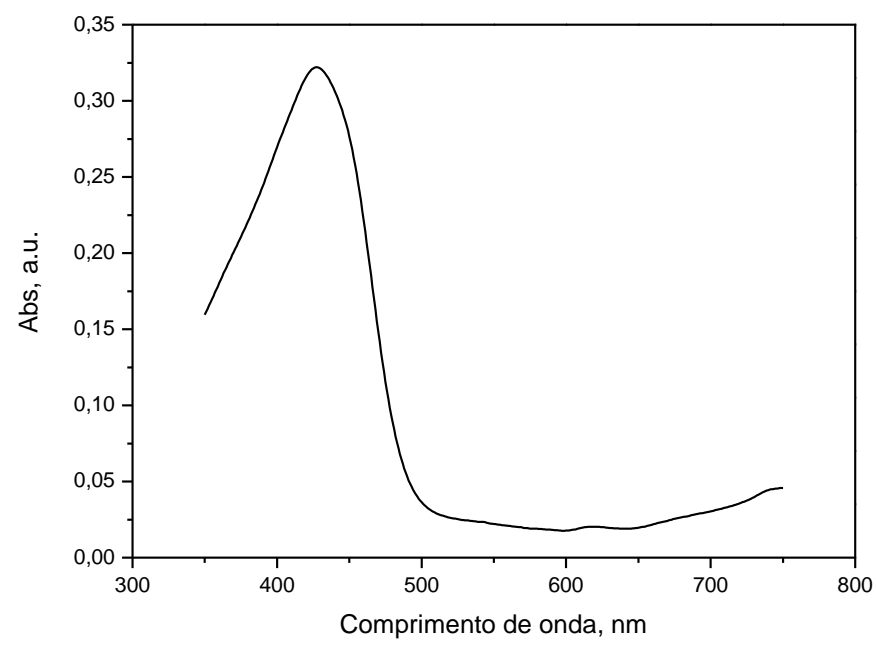

Figura 9 - Espectro UV-vis da curcumina em pH 4,0 a partir de uma solução de 2,71 mmol. $L^{-1}$. Fonte: Autoria própria

\subsubsection{Curva padrão de calibração da curcumina}

A curva de calibração para a curcumina foi determinada em um espectrofotômetro UV-vis U2M Quimis a partir de uma solução de curcumina, preparada utilizando-se $10 \mathrm{mg}$ de curcumina e dissolvida em solução composta de fosfato de sódio em pH 6,8 e etanol na proporção de 80:20 (tampão:etanol). A partir das diluições adequadas da solução estoque, foram realizadas as medidas de absorbância no comprimento de onde de $429 \mathrm{~nm}$ para cada solução. 
A curva padrão de calibração da curcumina foi determinada com o objetivo de auxiliar na determinação da taxa de associação da curcumina das nanopartículas, bem como na determinação do estudo de cinética de liberação da curcumina.

Dessa forma, a curva de calibração obtidas para a curcumina, está representada na Figura 10. Já na Tabela 2 está descrito o índice de correlação $\left(\mathrm{r}^{2}\right)$ obtido para curva padrão de calibração, bem como as equações utilizadas para determinar a concentração das soluções de curcumina.

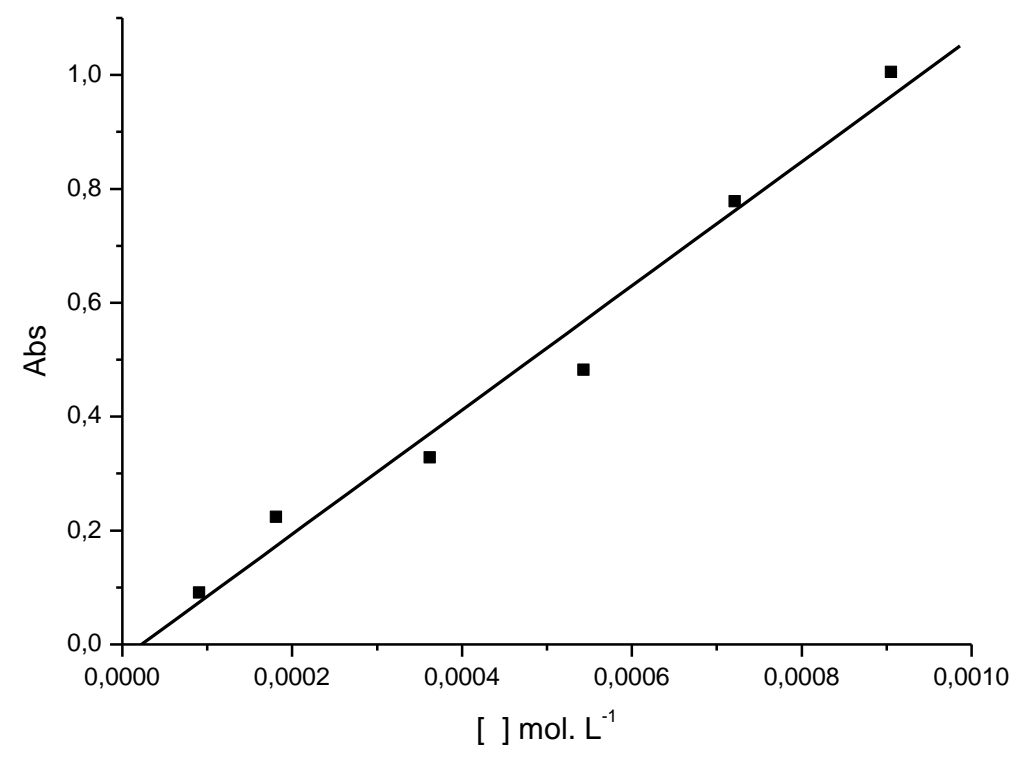

Figura 10 - Curva padrão de calibração da curcumina na solução fosfato $0,1 \mathrm{~mol} \mathrm{~L}^{-1} \mathrm{em} \mathrm{pH}$ 6,8. Fonte: Autoria própria

Tabela 1 - Dados referente a curva padrão de calibração $(y=a+b x)$ para determinação da concentração das soluções de curcumina

\begin{tabular}{c|c|c|c}
\hline pH das soluções & $\mathbf{a}$ & $\mathbf{b x}$ & Índice de correlação ( $\left.\mathbf{R}^{\mathbf{2}}\right)$ \\
\hline 6,8 & $-0,02447$ & $1090,03 \mathrm{x}$ & 0,98827 \\
\hline
\end{tabular}

Observando os dados apresentados na Figura 10 e na Tabela 1, observa-se que a curva apresenta bom acordo entre os pontos experimentais e a curva teórica, o que possibilita a determinação da concentração da curcumina na solução de pH 6,8.

\subsubsection{Preparação das nanopartículas}

A preparação das NPs de QTS/SC e QTS/SC/lecitina padrão e contendo curcumina foi realizada pelo método de gelatinização iônica, conforme descrito por Pan et al. (2002); Tiyaboonochal, (2003); Dasha et al. (2011); Tsai et al. (2011a); e Tagliari et al. (2012), 
considerando-se o estudo do diagrama de especiação, que evidencia o $\mathrm{pH}$ ideal para maior interação entre as espécies químicas provenientes da quitosana $\left(\mathrm{NH}_{3}{ }^{+}\right)$e do sulfato de condroitina $\left(\mathrm{SO}_{3}{ }^{-}\right.$e $\left.\mathrm{COO}^{-}\right)$, com base no pKa teórico dos biopolímeros apresentados na Tabela 2 (SKOOG et al, 2006; FARJADO, 2009).

Tabela 2: pKa teórico da quitosana e do sulfato de condroitina.

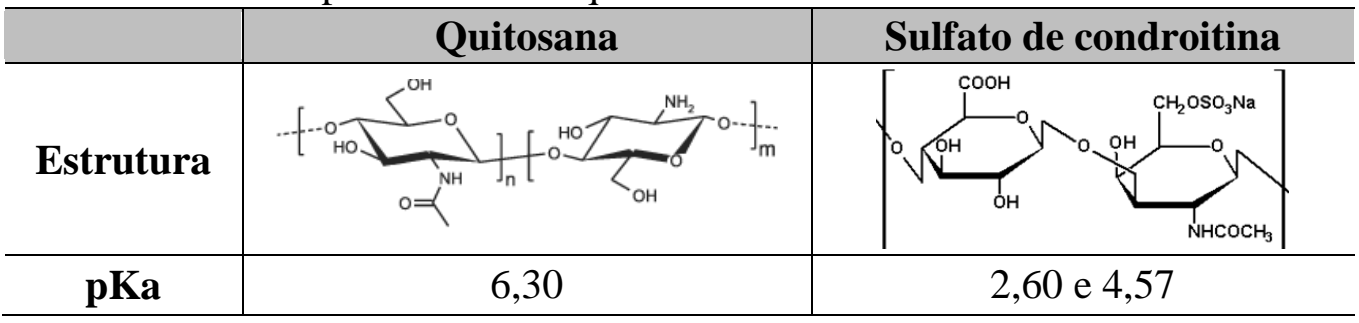

Fonte: Autoria própria.

Dentre os sistemas carreadores de compostos ativos, nanopartículas poliméricas constituídas por biopolímeros tem atraído atenção de muitos pesquisadores. Estes sistemas podem ser definidos como suspensões coloidais apresentando nanopartículas com tamanho menor do que $1000 \mathrm{~nm}$, sendo que a maioria varia entre 100-500 nm (QUINTANARGUERRERO et al., 1998). São consideradas potentes vetores, pois possuem boa capacidade de liberar compostos ativos (LEITE et al., 2007), conseguem estabilizar fármacos (OURIQUE et al., 2008) e são biocompatíveis e biodegradáveis (GUINEBRETIÈRE et al., 2002). Devido ao seu tamanho reduzido, podem facilmente atravessar barreiras biológicas, assim como, penetrar em todos os tipos de células.

Embora, biopolímeros naturais como o sulfato de condroitina apresente excelentes propriedades que justifica sua aplicação como carreador de fármaco, este biopolímero é altamente solúvel em água sob condições fisiológicas. Assim, uma alternativa para utilizá-lo como carreador de substâncias ativas consiste na formação de complexos polieletrolíticos (PECs), Figura 11, por meio da interação eletrostática com substâncias carregadas opostamente, já que o SC é um polieletrólito de caráter aniônico. Em contrapartida, a quitosana possui carga positiva sobre os grupos $-\mathrm{NH}_{3}{ }^{+}$quando dissolvida em solução aquosa ácida, facilitando sua solvatação em água e interação com compostos polianiônicos, como o sulfato de condroitina. Desta forma, a obtenção de nanopartículas baseadas na técnica de gelatinização iônica (interação eletrostática) entre estes biopolímeros torna o sistema nanoestruturado muito eficiente para encapsulação e liberação controlada de substâncias hidrofóbicas, como a curcumina. 


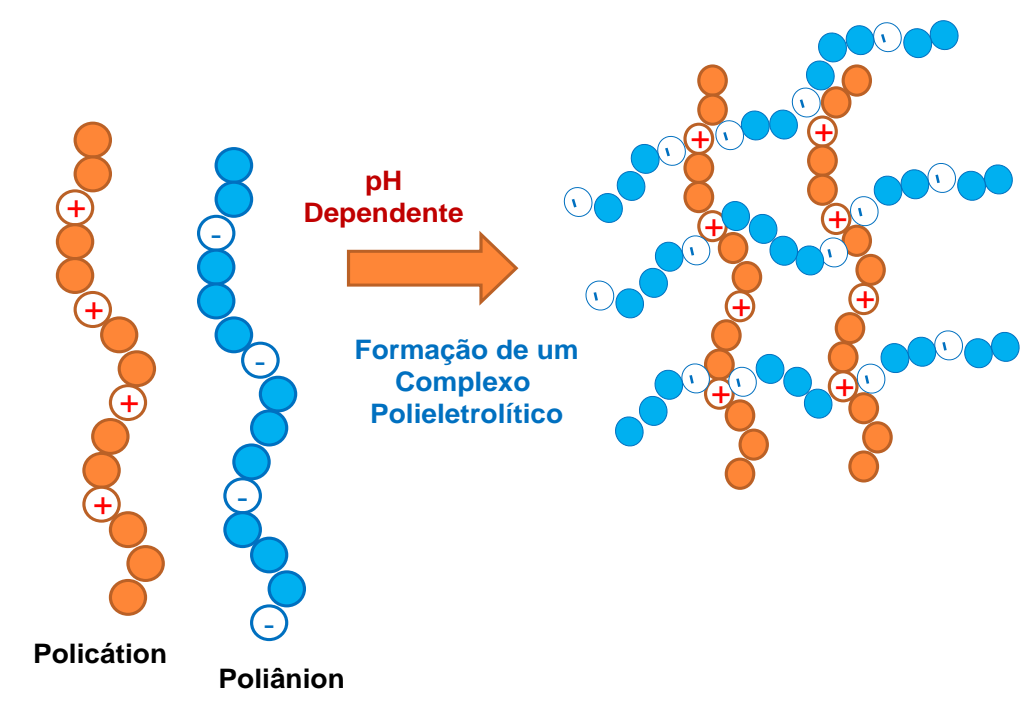

Figura 11 - Formação de complexo polieletrolítico. Fonte: Autoria própria.

No entanto, para que haja a formação efetiva do complexo polieletrolítico deve-se levar em consideração o pH da solução do policátion (quitosana) e do poliânion (sulfato de condroitina). Sabendo-se disto, elaborou-se, previamente, o diagrama de especiação, Figura 12, estabelecendo-se o pH ideal para maior interação entre as espécies químicas provenientes dos biopolímeros.

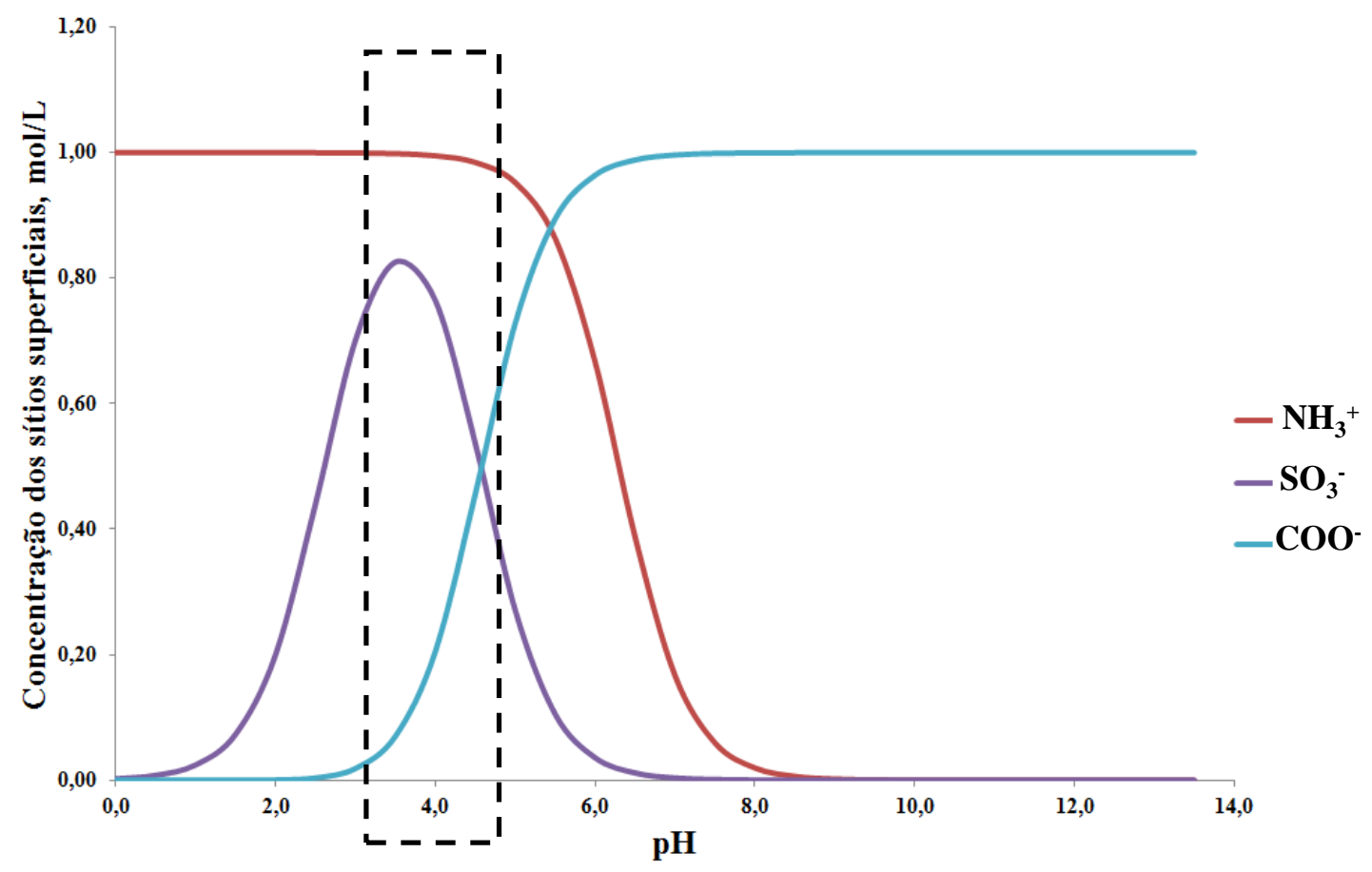

Figura 12 - Diagrama de especiação da superfície da quitosana e do sulfato de condroitina em função do pH. Fonte: Autoria Própria. 
No diagrama de especiação as concentrações dos sítios superficiais envolvidos são plotados em função do $\mathrm{pH}$. Desta forma, verificou-se que para a quitosana o $\mathrm{pH}$ ideal é 4,5 e para o sulfato de condroitina há uma faixa de $\mathrm{pH}$ que pode ser utilizada $(3,5$ a 6,5$)$, no entanto, neste estudo foi estabelecido o pH 3,5, onde há maior concentração de grupos sulfônicos, que favorecem interações mais fortes com os grupos amina da quitosana. Como no diagrama de especiação não é possível visualizar um $\mathrm{pH}$ ideal comum aos grupos amino e sulfônico, calculou-se a média entre os pHs individuais dos polímeros, obtendo-se um pH igual a 4,0 ideal para a interação entre as espécies químicas envolvidas.

Outro fator importante na obtenção de nanopartículas contendo fármaco é a presença de um surfactante. Neste estudo foi utilizado a lecitina (fosfatidilcolina) como agente de dispersão. Ao adicionar um surfactante nas nanopartículas ocorre uma alteração do diâmetro destas, resultando em nanopartículas mais compactas, já que quando dispersa sobre a superfície das nanopartículas tende a aumentar a repulsão eletrostática (SONVICO et al., 2006).

Com base nas informações fornecidas pelo diagrama de especiação, foram obtidas soluções homogêneas dos polímeros dissolvidas em ácido acético. A solução ácida de quitosana foi preparada dissolvendo-se cerca de $200 \mathrm{mg}$ de quitosana em $100 \mathrm{~mL}$ de solução de ácido acético $0,2 \mathrm{~mol} . \mathrm{L}^{-1}$, sob agitação magnética constante, por aproximadamente 40 minutos. Já a solução de sulfato de condroitina foi preparada dissolvendo-se cerca de $150 \mathrm{mg}$ de SC em $150 \mathrm{~mL}$ de solução de ácido acético 0,2 mol. $\mathrm{L}^{-1}$. Posteriormente o pH das soluções foi ajustado para 4,0, utilizando-se solução de $\mathrm{NaOH} 0,2$ mol. $\mathrm{L}^{-1}$.

A formação das NPs de QTS/SC foi conduzida a partir da adição lenta da solução de SC à solução de QTS, sob agitação magnética constante por aproximadamente 40 minutos, conforme mostrado na Figura 13, promovendo, desta forma, a complexação entre espécies de carga oposta. Nesta etapa a quitosana sofre gelatinização iônica e coagula na forma de nanopartículas esféricas, resultando, assim, em uma dispersão coloidal estável. 


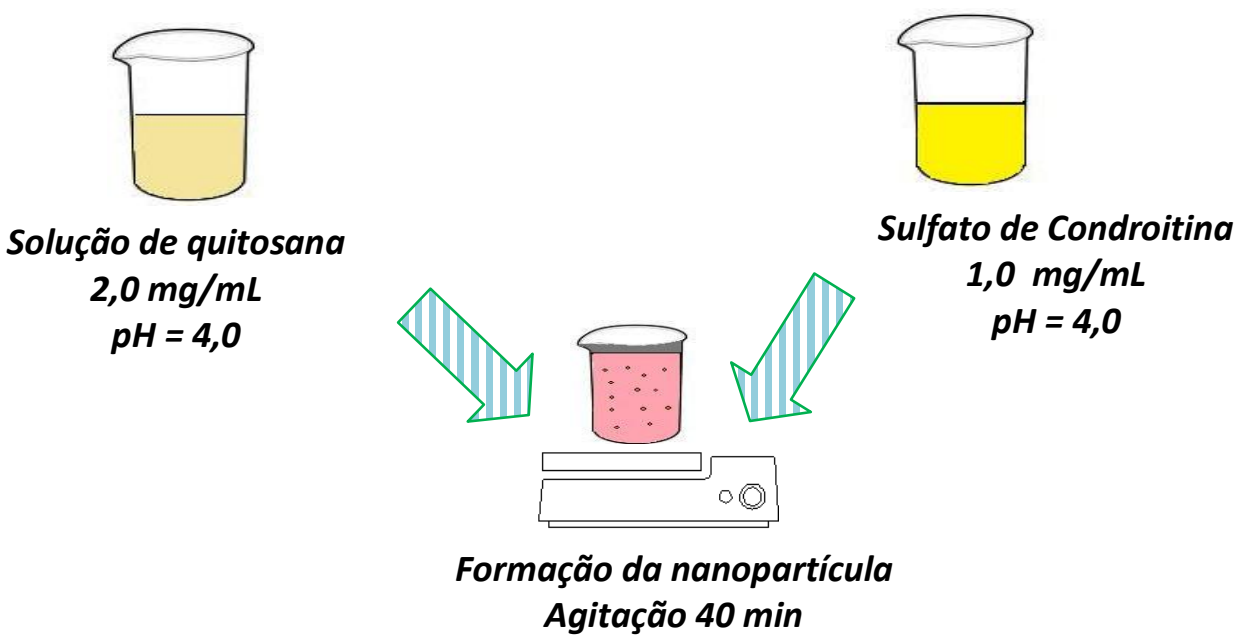

Figura 13 - Preparação de nanopartículas de quitosana / sulfato de condroitina através da técnica de gelatinização iônica. Fonte: Autoria própria

As NPs de QTS/SC/Lecitina foram obtidas conforme a metodologia empregada anteriormente, porém antes da adição do sulfato de condroitina foi adicionado o surfactante lecitina à solução polimérica de quitosana, mantendo a solução sob agitação por aproximadamente 10 minutos. Após este período adicionou-se lentamente o sulfato de condroitina, mantendo a agitação magnética por cerca de $40 \mathrm{~min}$.

A curcumina foi encapsulada às NPs de QTS/SC e QTS/SC/Lecitina, utilizando-se a também o método de gelatinização iônica, com algumas alterações, conforme representado nas Figuras 14 e 15. Na NPs de QTS/SC, a curcumina foi adicionada a solução de quitosana, promovendo primeiramente a sua interação com o polímero. Após a impregnação e estabilização do flavanóide na solução de quitosana, a solução de sulfato de condroitina foi adicionada lentamente à solução contendo QTS/curcumina sob agitação magnética constante por cerca 40 minutos. Já a incorporação da curcumina nas NPs de QTS/SC/Lecitina ocorreu com a prévia adição do surfactante à solução de quitosana e em seguida adicionou-se a curcumina e o sulfato de condroitina, deixando a solução sob agitação magnética por cerca de 40 minutos. 

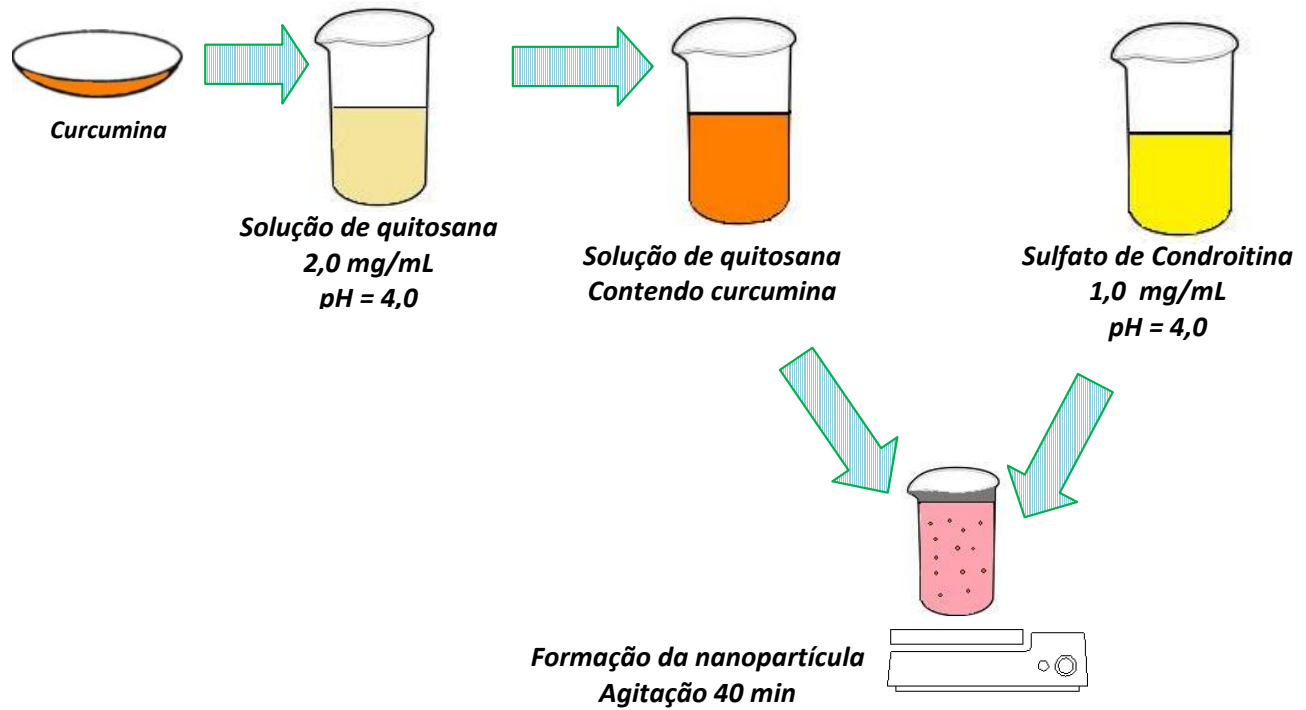

Figura 14 - Preparação de nanopartículas de quitosana / sulfato de contendo curcumina através da técnica de gelatinização iônica. Fonte: Autoria própria
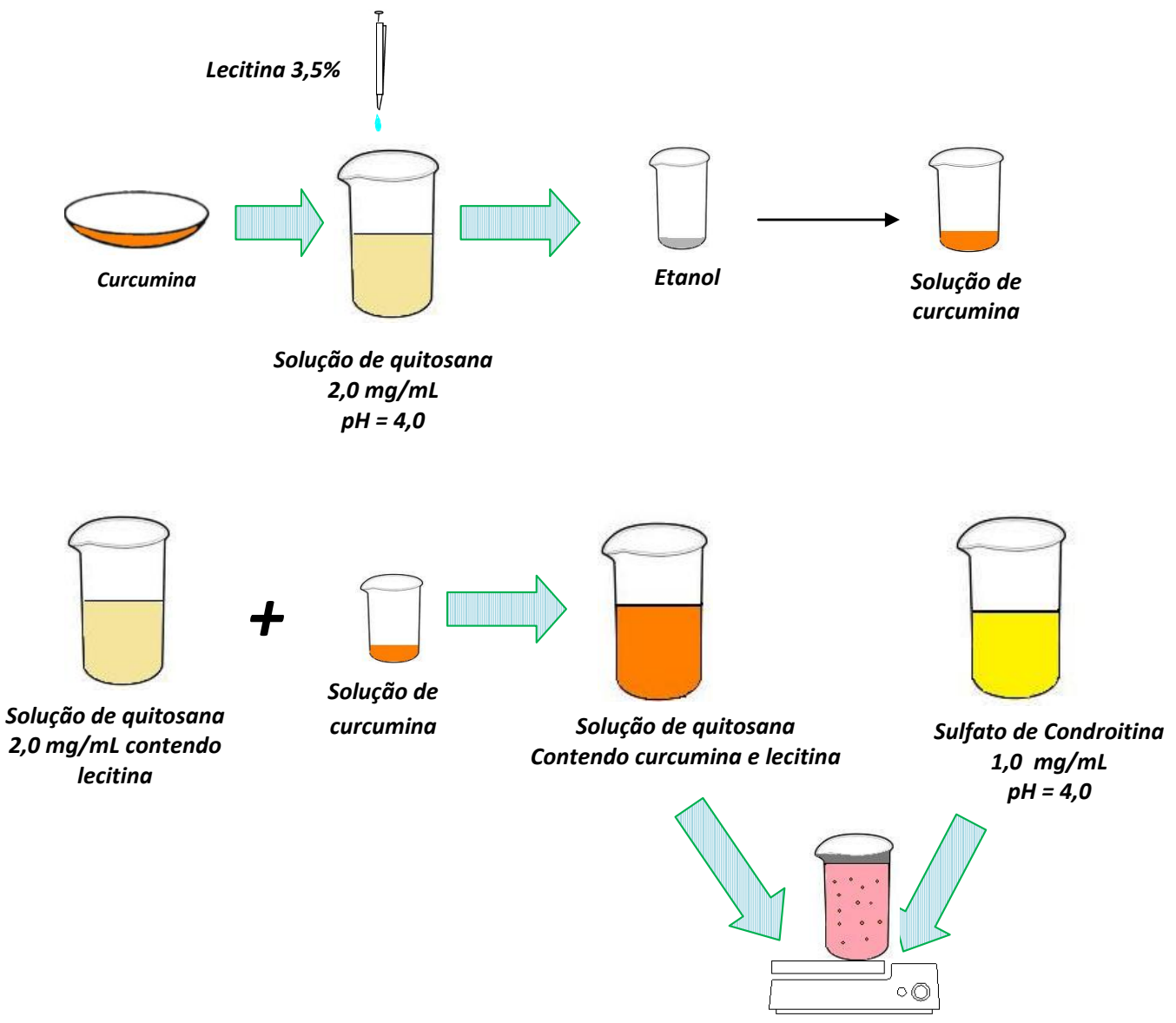

Formação da nanopartícula

Figura 15 - Preparação de nanopartículas de quitosana / sulfato de contendo curcumina e lecitina através da técnica de gelatinização iônica. Fonte: Autoria própria 
A quitosana e o sulfato de condroitina foram dissolvidos separadamente em solução de ácido acético 0,2 mol. $\mathrm{L}^{-1}$ e a curcumina foi incorporada na solução polimérica de quitosana por meio da preparação de uma solução alcóolica, dissolvendo-se cerca de $30 \mathrm{mg}$ de curcumina em aproximadamente $10 \mathrm{~mL}$ de etanol.

Após a obtenção das nanopartículas, estas foram transferidas para tubos falcon, centrifugada por 10 minutos a $3000 \mathrm{rpm}$ em uma centrifuga Hettich Zentrifugen, modelo Rotina 420 gr à $25^{\circ} \mathrm{C}$. A amostra foi ressuspensa em água tipo 1 , centrifugada novamente e o material resultante foi acondicionado à $-18^{\circ} \mathrm{C}$ para ser liofilizado, utilizando-se o Liofilizador Torrone L-300, a uma temperatura de $-45^{\circ} \mathrm{C}$ e pressão de 9,9 bar, obtendo-se nanopartículas na forma de pó, o que possibilitou a caracterização físico-química do material obtido.

\subsubsection{Caracterização das nanopartículas}

Com a finalidade de caracterizar as nanopartículas obtidas nesse estudo, foram avaliados o diâmetro hidrodinâmico, índice de polidispersão (PDI) e potencial zeta. Técnicas espectroscópicas e calorimétricas, ponderação da estabilidade físico-química das nanopartículas em suspensão, avaliação morfológica, estimativa da eficiência de encapsulação da substância ativa (curcumina) nas NPs e estudo da cinética de liberação da curcumina.

\subsubsection{Determinação do diâmetro hidrodinâmico, PDI e potencial zeta das nanopartículas}

A caracterização do diâmetro hidrodinâmico, PDI e potencial zeta das nanopartículas foi realizada, utilizando-se o equipamento de espealhamento de luz dinâmico Nano-Zetasizer - ZS, modelo ZEN3600 - Malvern Instruments, situado na FCE (UnB/Ceilândia). O equipamento opera com uma fonte de luz (laser vermelho de $5 \mathrm{~mW}, \mathrm{He}-\mathrm{Ne}$ ), comprimento de onda em $633 \mathrm{~nm}$, e detector posicionado em um ângulo fixo de $173^{\circ}$ em relação ao ângulo de incidência, e as medidas foram realizadas à temperatura ambiente $\left(25^{\circ} \mathrm{C}\right)$ e utilizando-se água como dispersante.

Para as análises de diâmetro hidrodinâmico e PDI, as amostras foram previamente agitadas por aproximadamente 30 minutos, a fim de que as nanopartículas ficassem em suspensão, em seguida transferiu-se uma alíquota de $25 \mu \mathrm{L}$ da amostra para uma cubeta de poliestireno com $1 \mathrm{~cm}$ de caminho óptico e acresentou-se cerca de 1,5 $\mathrm{mL}$ de água tipo 1 . 
Cada análise foi realizada em triplicata, sendo que cada uma representa a média de 12 leituras em cada ponto. Os dados foram tratados com o software Zetasizer $6.20^{\circledR}$.

Para determinar o potencial zeta das NPs, $700 \mu \mathrm{L}$ da suspensão coloidal preparada para medida do diâmetro hidrodinâmico e PDI, foi transferida para uma célula eletroforética e as medidas foram realizadas, utilizando-se equipamento (Nano-Zetasizer ZS), alterando apenas a configuração do equipamento do modo size para o modo zeta.

\subsubsection{Avaliação da estabilidade físico-químicas das nanopartículas em suspensão}

As nanopartículas foram preparadas conforme descrito no iten 4.2.4, sendo mantidas em suspensão e acondicionadas em duas diferentes temperaturas $4^{\circ} \mathrm{C}$ e $25^{\circ} \mathrm{C}$ durante 90 dias. A avaliação da estabilidade físico-química das nanopartículas em suspensão foi realizada, considerando-se os parâmetros diâmetro hidrodinâmico, PDI, potencial zeta e pH. Para as medidas de diâmetro hidrodinâmico, PDI, potencial zeta utilizou-se o equipamento de espalhamento de luz dinâmico Nano-Zetasizer - ZS, modelo ZEN3600 - Malvern Instruments.

\subsubsection{Eficiência de encapsulação da curcumina às nanopartículas (\%EE)}

A eficiência de encapsulação da curcumina (\%EE) às nanopartículas de QTS/SC foi determinada por meio do método direto, empregando-se medidas espectroscópicas, no comprimento de onda máximo da absorção da curcumina, e aplicando-se os valores obtidos na equação de curva padrão de calibração da curcumina, referente à solução de $\mathrm{CH}_{3} \mathrm{COOH}$ 0,1 mol.L $\mathrm{L}^{-1}$ em $\mathrm{pH} 4,0$.

Aproximadamente $30 \mathrm{mg}$ das nanopartículas de QTS/SC/Curcumina e NPS QTS/SC/Lecitina/Curcumina, ambas liofilizadas foram dissolvidas em $8 \mathrm{~mL}$ de solução de $\mathrm{CH}_{3} \mathrm{COOH}$ 0,1 mol.L $\mathrm{L}^{-1} \mathrm{em} \mathrm{pH} \mathrm{4,0} \mathrm{e} \mathrm{em} \mathrm{seguida} \mathrm{adicionado} 2 \mathrm{~mL}$ de etanol. Após a extração da curcumina encapsulada nas nanopartículas, uma alíquota $(3 \mathrm{~mL})$ da solução resultante de cada amostra foi coletada e analisada, utilizando-se um espectrofotômetro UV-vis U2M Quimis, no comprimento de onda máximo de $429 \mathrm{~nm}$, obtendo-se a concentração de curcumina encapsulada em cada NPs. A eficiência de encapsulação da curcumina foi determinada utilizando-se a equação 2 : 
$\%$ EE $=\frac{\text { Quantidade de curcumina associada }}{\text { Quantidade inicial de curcumina }} \times 100 \%$

(Equação 2)

\subsubsection{Avaliação morfológica das nanopartículas}

A avaliação morfológica das nanopartículas desenvolvidas neste estudo foi realizada utilizando-se um microscópio eletrônico de transmissão, modelo $J E O L J E M$-2100, equipado com EDS, Thermo scientific. As suspensões coloidais de cada NPs desenvolvida no estudo, foram diluídas em água Tipo 1 , em uma razão de $50 \mu \mathrm{L}$ da amostra para $100 \mu \mathrm{L}$ de água. Após a diluição, uma alíquota de $5 \mu \mathrm{L}$ da suspensão coloidal e $5 \mu \mathrm{L}$ de contraste de ácido fosfotúngico $2 \%$, foram depositados sobre uma tela de cobre com 400 mesh, recoberta por um filme de carbono. Após a deposição a tela de cobre foi seca à temperatura ambiente $\left(25^{\circ} \mathrm{C}\right)$ por aproximadamente $24 \mathrm{~h}$ e posteriormente analisada.

\subsubsection{Espectroscopia de infravermelho (FTIR)}

Os espectros de infravermelho, para todas as amostras, foram obtidos na região de 4000 - $400 \mathrm{~cm}^{-1}$, utilizando-se pastilhas de $\mathrm{KBr}$ e um espectrofotômetro FT-IR Varian 640IR, com resolução de $2 \mathrm{~cm}^{-1}$, via análise de 32 scans.

\subsubsection{Análise Termogravimétrica (TGA)}

As análises termogravimétricas das nanopartículas preparadas neste estudo foram realizadas utilizando o equipamento Shimadzu TG 60. Durante a análise a temperatura variou entre $25^{\circ} \mathrm{C}$ e $600^{\circ} \mathrm{C}$, com razão de aquecimento de $10^{\circ} \mathrm{C} / \mathrm{min}$ e fluxo de ara $50 \mathrm{~mL} / \mathrm{min}$, a fim de verificar a degradação dos biopolímeros e das nanopartículas formadas por meio destes, bem como avaliar a estabilidade térmica dos materiais envolvidos neste estudo.

\subsubsection{Perfil de liberação da Curcumina}

A cinética de liberação da curcumina, a partir das nanopartículas de QTS/SC e QTS/SC/Lecitina, foi realizada em solução de fosfato de sódio em pH 6,8. A análise foi realizada utilizando-se um espectrofotômetro UV-vis U2M Quimis em $\lambda_{\text {máx }} 429 \mathrm{~nm}$. 
As nanopartículas foram previamente preparadas conforme descrito no item 4.2 .4 e o $\mathrm{pH}$ da solução de fosfato de sódio foi ajustado utilizando-se solução de $\mathrm{NaOH}$ 0,1 mol. $\mathrm{L}^{-1}$. Para realização da leitura de absorbância aproximadamente $30 \mathrm{mg}$ de nanopartículas preparadas e posteriormente liofilizadas foram suspensas em $30 \mathrm{~mL}$ de solução de fosfato de sódio pH 6,8.

Após a adição da solução tampão as NPs, em intervalos pré-determinados, transferiuse aproximadamente $3 \mathrm{~mL}$ do sobrenadante para uma cubeta, sendo a solução analisada por espectroscopia de UV-vis. A análise foi conduzida por 240 h e o comportamento de liberação da curcumina foi observado em temperatura ambiente $\left(25^{\circ} \mathrm{C}\right)$ e sob agitação magnética constante nas primeiras $\mathrm{h}$ de liberação, e com ocasional agitação antes da leitura de absorbância.

A porcentagem de curcumina liberada foi determinada, utilizando-se a curva padrão de calibração que relaciona a absorbância com a concentração conhecida da curcumina na mesma solução em que a cinética de liberação foi conduzida. Os resultados obtidos para a liberação cumulativa da curcumina foram calculados, utilizando-se a equação 3 :

Curcumina liberada $(\%)=\frac{\text { Quantidade de curcumina liberada }}{\text { Quantidade de curcumina encapsulada }} \times 100 \%$

(Equação 3)

\subsubsection{Avaliação da atividade citotóxica in vitro da curcumina livre e nanoencapsulada}

A avaliação citotóxica teve como objetivo avaliar se a curcumina e as nanopartículas contendo curcumina interferem na viabilidade de células tumorais. Os ensaios foram realizados utilizando-se células tumorais humanas de mama da linhagem MCF-7. Todos os procedimentos foram realizados, utilizando-se materiais rigorosamente esterilizados, e executado no interior de uma câmara de fluxo laminar da marca Veco, modelos CFLV 12, cuja luz ultravioleta permaneceu ligada por 25 a 30 minutos antes do início do procedimento.

\subsubsection{Manutenção das células}

As células de câncer de mama (alíquotas de $500 \mu \mathrm{L}$ ) foram removidas de um estoque em nitrogênio líquido e rapidamente descongeladas a $37^{\circ} \mathrm{C}$. Em seguida as células foram centrifugadas a $750 \mathrm{~g}$ por 2 minutos, ressuspensas em $10 \mathrm{~mL}$ de meio de cultura RPMI 1640 (R6504, Sigma-Aldrich) e adicionadas a frascos de cultura com volume de $75 \mathrm{~cm}^{3}$. Esses 
frascos foram então incubados por $48 \mathrm{~h}$ em estufa da marca Thermo Scientífic ${ }^{\circledR}$, modelo 8.000 WJ, com $5 \%$ de $\mathrm{CO}_{2}$, mantida úmida e a uma temperatura de $37^{\circ} \mathrm{C}$. O meio de cultura foi suplementado com $2 \mathrm{~g} \mathrm{~L}^{-1}$ de bicarbonato de sódio e $10 \%$ de soro fetal bovino (SFB).

Para garantir a qualidade das células utilizadas nos experimentos, a cada $48 \mathrm{~h}$ o meio de cultura era substituído por um meio de cultura fresco. A cultura de célula foi periodicamente observada por meio de um microscópio óptico invertido da marca Olympus ${ }^{\circledR}$, modelo CK2, a fim de se avaliar as condições celulares como: crescimento, aspectos morfológicos e presença de contaminantes.

Após atingir o estágio de confluência, elevada densidade de células em uma determinada área, as células foram removidas do frasco de cultura e recultivadas em uma densidade menor. Para isto o meio de cultura contido na garrafa foi descartado e as células removidas do frasco pela adição de $4 \mathrm{~mL}$ de solução estoque de tripsina/EDTA. O frasco foi mantido na estufa por aproximadamente 2 minutos, na temperatura de $37^{\circ} \mathrm{C}$ e $5 \%$ de $\mathrm{CO}_{2}$. Ao observar por meio do microscópio que as células estavam suspensas, adicionou-se $1 \mathrm{~mL}$ de meio de cultura RPMI 1640, para neutralizar a ação da tripsina, e o conteúdo foi então transferido para um tubo falcon de $15 \mathrm{~mL}$ e centrifugado a $750 \mathrm{~g}$, por 2 minutos. Em seguida, descartou-se o sobrenadante e as células precipitadas foram ressuspensas em meio de cultura, para então proceder à contagem do número de células.

\subsubsection{Contagem celular}

A fim de determinar o número de células, $10 \mu \mathrm{L}$ da suspensão de células foram transferidos para um microtubo juntamente com $40 \mu \mathrm{L}$ de solução estoque de $0,4 \%$ de azul de tripan (p/v). $8 \mu \mathrm{L}$ dessa mistura foram depositados em uma câmara de Neubauer, onde apenas as células encontradas nos quatro quadrantes dos extremos maiores laterais foram visualizadas, e contadas com o auxilio do microscópio óptico invertido. Assim, a quantidade de células foi determinada de acordo com a equação 4.

$$
\text { Número de células } / m L=\frac{N^{o} \text { de Células contadas }}{4} \times 5 \times 10^{4}
$$

\section{(Equação 4)}

Após a determinação da quantidade de células, parte delas foi transferida para um frasco de cultura e mantida na estufa a $37^{\circ} \mathrm{C}, 5 \%$ de $\mathrm{CO}_{2}$ e, com os outros $875 \mu \mathrm{L}$ de suspensão celular remanescente realizou-se o ensaio de viabilidade celular. 


\subsubsection{Ensaio de viabilidade celular}

Para a realização do ensaio de viabilidade celular, as células contadas foram transferidas para placas de cultura de 96 poços, incubadas em estufa a $37^{\circ} \mathrm{C}$ e $5 \%$ de $\mathrm{CO}_{2}$ por 24 h para a completa adesão das células no fundo da placa. A concentração padrão de células adotada foi de $5 \times 10^{3}$ célula/poço, e o volume de suspensão celular transferido para cada poço foi determinado segundo a equação 5:

Volume de suspensão celular em $m L /$ poço $=\frac{5 \times 10^{3}}{N^{o} \text { de célula } / m L}$

(Equação 5)

Após 24 h de incubação, as placas contendo a cultura de células foram observadas em microscópio óptico invertido para a avaliação da morfologia, dispersão das células pela placa e presença de contaminação. Em seguida, iniciou-se a fase de tratamento das células. Para isto, retirou-se o meio de cultura contido nas placas e adicionou-se $200 \mu \mathrm{L}$ da solução de meio de cultura contendo as amostras em estudo.

As amostras estudadas foram NPs de QTS/SC e QTS/SC/Lecitina padrão e contendo curcumina, curcumina livre, sulfato de condroitina, solução de ácido acético, solução de etanol/água, solução lecitina/água e água. A concentração das amostras variou de 10 a 40 $\mu \mathrm{mol} \mathrm{L} \mathrm{L}^{-1}$. Para cada concentração foi realizada uma triplicata, e após o tratamento as células foram mantidas incubadas em estufa pelo período de 24,48 e $72 \mathrm{~h}$.

As NPs de QTS/SC e QTS/SC/Lecitina padrão e contendo curcumina foram preparadas conforme descrito nos itens 4.2.4. A solução de curcumina livre foi preparada utilizando-se $8 \mathrm{mg}$ de curcumina diluída em solução de etanol/água em uma razão de 80:20, sendo $20 \mathrm{~mL}$ de etanol e $80 \mathrm{~mL}$ de água.

No entanto, como as células não sobrevivem nos pHs ácidos, as nanopartículas padrão e contendo curcumina e seu respectivo controle ácido tiveram seus $\mathrm{pHs}$ ajustados para o $\mathrm{pH}$ fisiológico $(7,4)$, com solução de $\mathrm{NaOH} 10 \mathrm{~mol} \mathrm{~L}^{-1}$.

Após cada período de incubação, o meio contendo as amostras em estudo, foi removido, e adicionou-se $15 \mu \mathrm{L}$ de solução estoque de MTT (3(4,5-dimethylthiazol-2-yl)-2,5dipHenyltetrazolium bromide) e $135 \mu \mathrm{L}$ de meio de cultura fresco. As placas foram novamente mantidas na estufa a $37^{\circ} \mathrm{C}, 5 \%$ de $\mathrm{CO}_{2}$ por aproximadamente duas h. Após esse período, removeu-se a solução do meio de cultura e MTT e adicionou-se $200 \mu \mathrm{L}$ de DMSO, homogeneizando-se o sistema com o auxilio de uma micropipeta para que os cristais de 
formazan (um produto de cor azulada), formados pelo metabolismo celular na presença do MTT, fossem completamente solubilizados no DMSO. De tal modo, foi possível realizar a leitura da absorbância do formazan por meio de um espectrofotômetro acoplado a um leitor de microplacas da marca SpectraMax ${ }^{\circledR}$, modelo M2, Molecular Devices, em comprimento de onda de $595 \mathrm{~nm}$. A viabilidade das células dos grupos controle foi considerada como máxima (100\%) e a porcentagem de células viáveis que haviam sido submetidas a algum dos tratamentos foi determinada a partir dessa consideração. A porcentagem de células viáveis foi calculada de acordo com a equação 6:

Células viáveis $(\%)=\frac{\text { Absorbância para grupo tratado }}{\text { Absorbância para grupo controle }} \times 100$

(Equação 6)

Com o término dos experimentos as células a serem desprezadas, bem como todo material que foi utilizado durante o ensaio, receberam adição de hipoclorito de sódio e detergente e foram lavados ou descartados após 24 horas.

\subsubsection{Controle positivo}

O controle positivo para o ensaio de MTT foi realizado seguindo a mesma metodologia utilizada na avaliação da citotoxicidade da curcumina livre e encapsulada em nanopartículas de QTS/SC e QTS/SC/Lecitina com a diferença que no controle positivo as células (MCF-7) foram tratadas com peróxido de hidrogênio na concentração de 2 a 5 mmolL ${ }^{1}$. Após $24 \mathrm{~h}$ de incubação em estufa a $37^{\circ} \mathrm{C}$ e $5 \%$ de $\mathrm{CO}_{2}$, o meio contendo o peróxido de hidrogênio, foi removido, e adicionou-se $15 \mu \mathrm{L}$ de solução estoque de MTT e $135 \mu \mathrm{L}$ de meio de cultura (RPMI 1640) fresco. As placas foram novamente mantidas na estufa a $37^{\circ} \mathrm{C}, 5 \%$ de $\mathrm{CO}_{2}$ por aproximadamente $2 \mathrm{~h}$. Após esse período, removeu-se a solução do meio de cultura e MTT e adicionou-se $200 \mu \mathrm{L}$ de DMSO, homogeneizando-se o sistema com o auxilio de uma micropipeta para que os cristais de formazan fossem completamente solubilizados no DMSO. De tal modo, foi possível realizar a leitura da absorbância do formazan por meio de um espectrofotômetro acoplado a um leitor de microplacas, em comprimento de onda de $595 \mathrm{~nm}$. A partir dos dados obtidos verificou-se que o MTT detecta adequadamente células com baixa viabilidade, pois como estas concentrações de peróxido de hidrogênio é tóxico para as células, estas apresentaram viabilidade inferior a $10 \%$ no ensaio de MTT. 


\subsubsection{Análise estatística}

Os experimentos foram realizados em triplicata e os dados obtidos foram apresentados como média \pm desvio padrão da média. A determinação das diferenças estatisticamente significativas entre os grupos avaliados foi realizada por meio da análise de variância (ANOVA) com teste estatístico de Tukey, utilizando-se o software GrapHPad Prism ${ }^{\circledR}$ versão 5,0 , sendo considerado estatisticamente significativo $\mathrm{p}<0,001$. 


\section{RESULTADOS E DISCUSSÃO}

\subsection{Determinação do diâmetro hidrodinâmico, PDI e potencial zeta}

Considerando-se o estudo de especiação e a adição do surfactante lecitina, verificou-se que as nanopartículas preparadas pelo método de gelatinização iônica apresentaram uma distribuição estreita, menor diâmetro hidrodinâmico e um potencial zeta positivo com valor em módulo alto, indicando boa estabilidade coloidal, conforme apresentado na Tabela 3.

Tabela 3 - Diâmetro hidrodinâmico, PDI e potencial zeta das NPs de QTS/SC e QTS/SC/Lecitina padrão e contendo curcumina.

\begin{tabular}{c|c|c|c}
\hline Amostra & ${\text { Diâmetro }(\mathbf{n m})^{\mathbf{a}}}^{\text {QTS/SC }}$ & PDI $^{\mathbf{a}}$ & Potencial Zeta (mV) $^{\mathbf{a}}$ \\
\hline QTS/SC/Lecitina & $379,5 \pm 22,8$ & $0,429 \pm 0,02$ & $+58,2 \pm 2,5$ \\
QTS/SC/Curcumina & $415,0 \pm 16,5$ & $0,384 \pm 0,02$ & $+59,7 \pm 2,2$ \\
QTS/SC/Lecitina/Curcumina & $406,2 \pm 7,6$ & $0,391 \pm 0,02$ & $+60,4 \pm 1,1$ \\
\hline
\end{tabular}

${ }^{\mathrm{a}}$ análise realizada em triplicata, $\mathrm{n}=3$.

Ao analisar as características das NPs de QTS/SC e QTS/SC/Lecitina padrão e contendo curcumina verificou-se que a adição do surfactante promoveu uma redução no diâmetro hidrodinâmico e no PDI e um aumento no potencial zeta das nanopartículas.

A diminuição no diâmetro hidrodinâmico das NPs sob influência de lecitina pode ser explicado pela interação eletrostática que ocorre entre a quitosana e o surfactante, na qual as moléculas de lecitina tendem a formar um núcleo caracterizado pelas cadeias alifáticas da lecitina enquanto as moléculas de quitosana formam uma camada hidrofílica decorrente da interação da QTS com os grupos fosfatos da lecitina para proteção da estrutura interna.

Já o aumento no potencial zeta pode ser explicado em decorrência da presença de um grupo $\mathrm{NH}_{3}{ }^{+}$na estrutura do surfactante que aumenta a densidade de carga positiva na superfície das NPs formadas.

Ao adicionar o surfactante nas nanopartículas sua carga superficial é alterada em comparação com a partícula original e os dados obtidos demonstram uma diminuição do tamanho da nanopartícula, o que pode ser desencadeado pela menor probabilidade de 
agregação ou pelo aumento da força de repulsão eletrostática entre a quitosana e lecitina presentes na nanopartícula (HUN-YU TSAI et al., 2011).

Além disso, ao comparar os dados das NPs de QTS/SC e QTS/SC/Lecitina padrão e contendo curcumina, foi possível observar que ocorreu um aumento nas características das nanopartículas, que pode ser justificada devido à interação dos grupos $\mathrm{NH}_{3}{ }^{+}$da quitosana com os grupos fenólicos da curcumina.

A adição de lecitina propicia uma diminuição do diâmetro hidrodinâmico das nanopartículas em decorrência das interações eletrostáticas, promovendo, assim, um aumento na densidade de carga positiva, resultando em sistemas mais polidispersos e estáveis.

Com isso, verificou-se que o método de gelatinização iônica é um método eficaz, simples, rápido, não necessitando de equipamentos sofisticados para obtenção de nanopartículas poliméricas. Além disso, o método aliado ao estudo de especiação possibilitou o desenvolvimento de nanopartículas com características mais adequadas a um sistema de liberação controlada de fármaco.

\subsection{Avaliação da estabilidade físico-químicas das nanopartículas em suspensão}

Realizou-se a avaliação da estabilidade físico-química das NPs de QTS/SC e QTS/SC/Lecitina padrão e contendo curcumina, por meio do monitoramento dos parâmetros: diâmetro hidrodinâmico, PDI, potencial zeta e $\mathrm{pH}$ durante o período de 90 dias. As nanopartículas foram preparadas conforme descrito no item 4.2.4 e acondicionadas em duas diferentes temperaturas: $4^{\circ} \mathrm{C}$ e $25^{\circ} \mathrm{C}$.

Os dados obtidos no estudo de estabilidade coloidal, considerando o parâmetro diâmetro hidrodinâmico e potencial zeta para as NPs de QTS/SC e QTS/SC/Lecitina padrão e contendo curcumina, estão apresentados nas Figuras 16, 17, 18, 19. Os dados de PDI estão apresentados na Tabela 4 . 

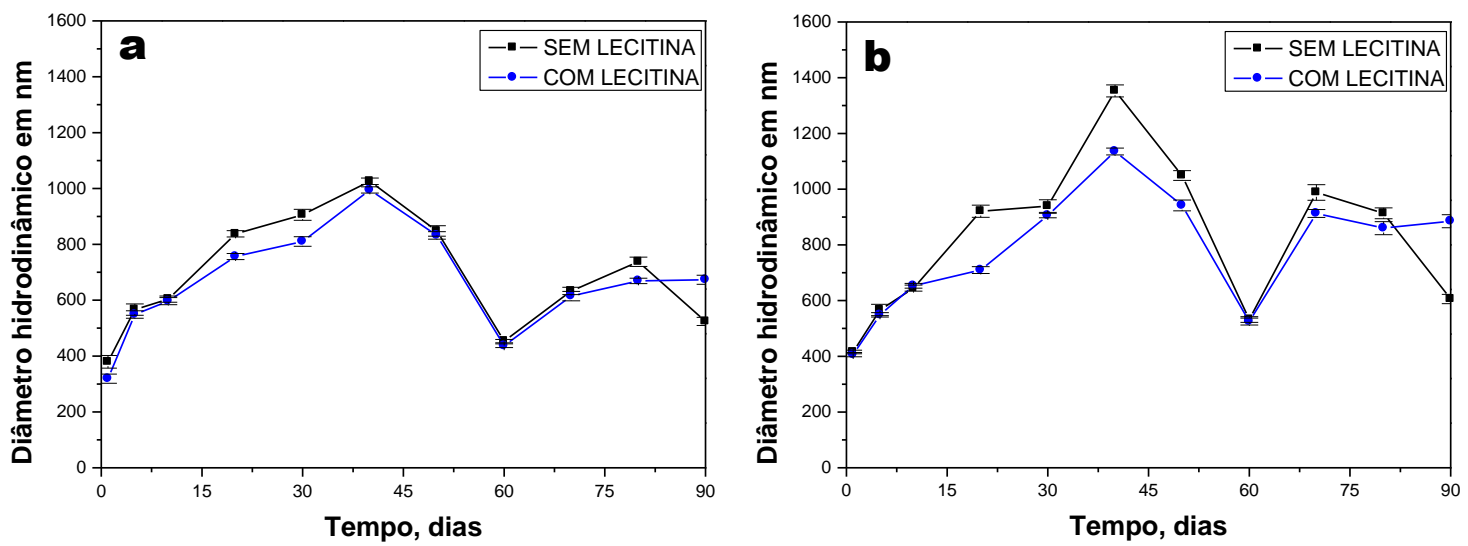

Figura 16 - Diâmetro hidrodinâmico das NPs de: (a) QTS/SC com e sem lecitina, (b) QTS/SC/Curcumina com e sem lecitina na temperatura de $25^{\circ} \mathrm{C}$ durante o período de 90 dias.
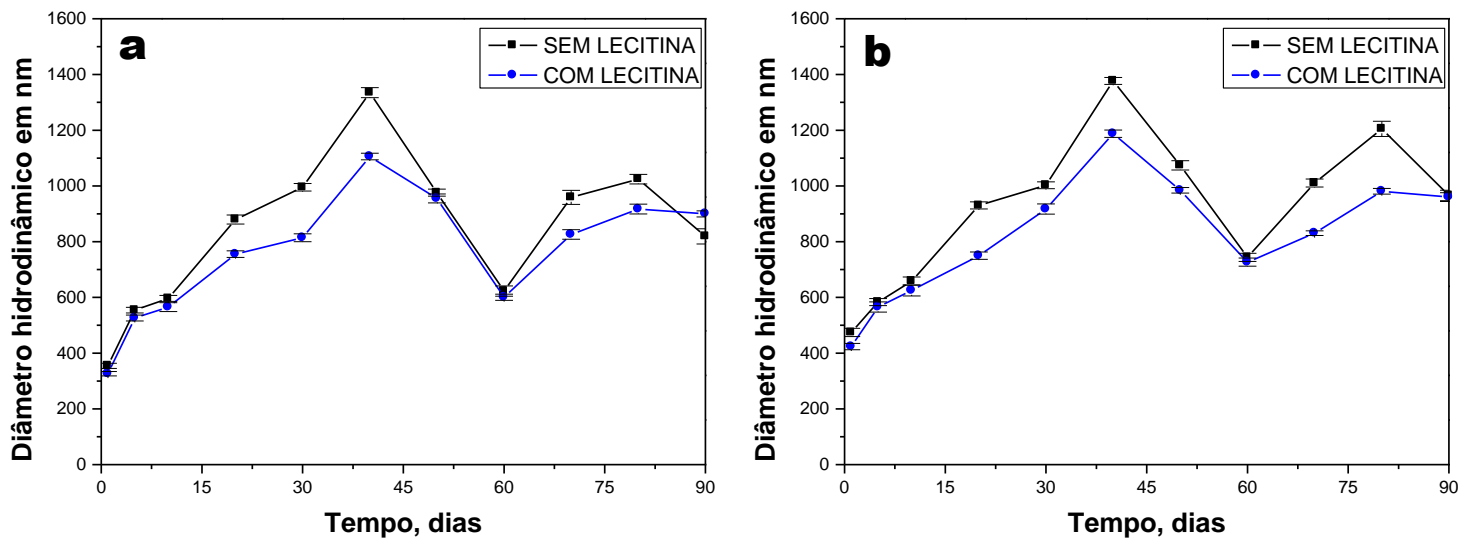

Figura 17 - Diâmetro hidrodinâmico das NPs de: (a) QTS/SC com e sem lecitina, (b) QTS/SC/Curcumina com e sem lecitina na temperatura de $4^{\circ} \mathrm{C}$ durante o período de 90 dias.

Ao avaliar o diâmetro hidrodinâmico observa-se que as nanopartículas analisadas, apresentaram variações com relação a esta característica, indicando que com o passar do tempo há uma tendência a formação de aglomerados. No estudo conduzido, mesmo verificando-se o aumento do tamanho das nanoparticulas não se observa a formação de precipitados.

Com base nos dados obtidos, com relação ao parâmetro potencial zeta, as NPs, se apresentaram, de maneira geral, estáveis, pois ao longo do tempo, as variações observadas foram pouco significativas. Em todas as amostras os valores de potencial zeta foram relativamente altos, maiores $\pm 56 \mathrm{mV}$, conferindo-lhes a este sistema coloidal boa estabilidade físico-química, fazendo com que o mesmo resista mais facilmente a agregação. 

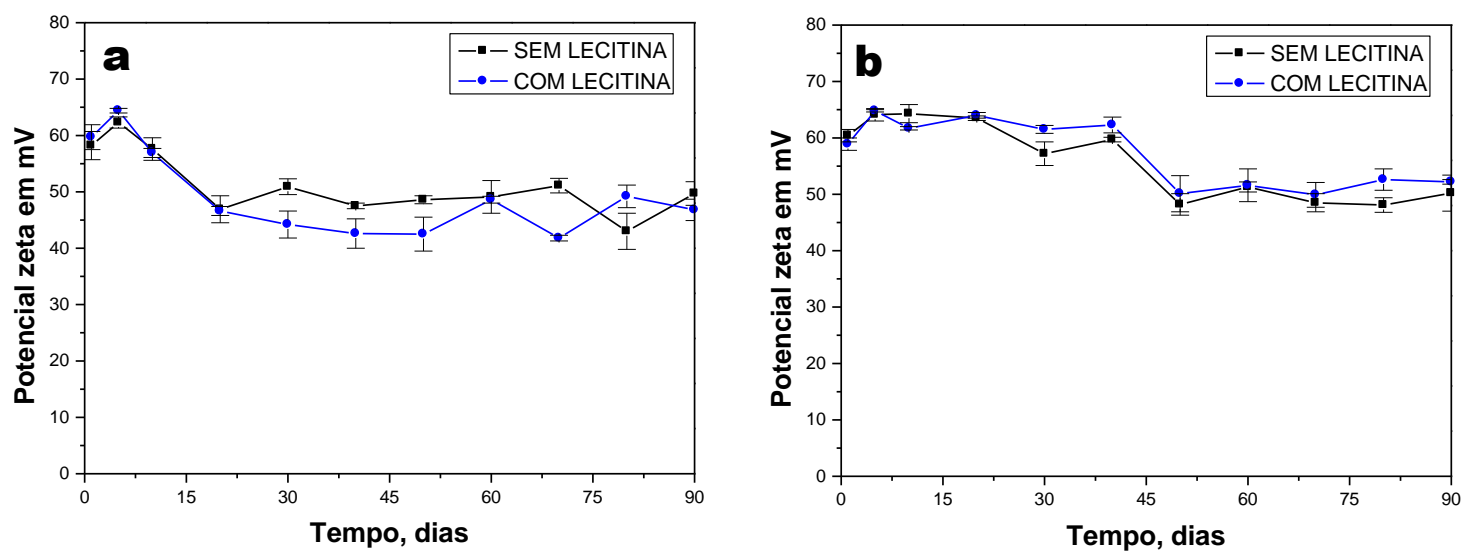

Figura 18 - Potencial zeta das NPs de: (a) QTS/SC com e sem lecitina, (b) QTS/SC/Curcumina com e sem lecitina na temperatura de $25^{\circ} \mathrm{C}$ durante o período de 90 dias.
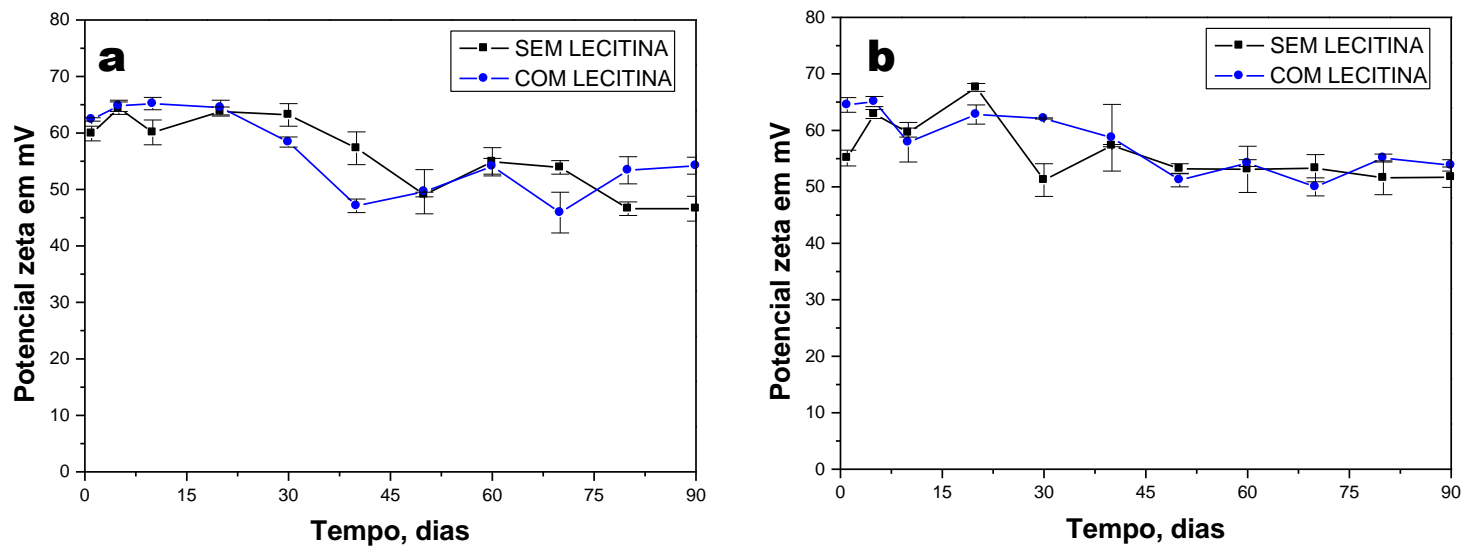

Figura 19 - Potencial zeta das NPs de: (a) QTS/SC com e sem lecitina, (b) QTS/SC/Curcumina com e sem lecitina na temperatura de $4^{\circ} \mathrm{C}$ durante o período de 90 dias.

Com relação à polidispersão do sistema observa-se que para as amostras deste estudo o melhor valor de PDI encontrado é 0,230 conforme Tabela 4, e são para as amostras na presença do surfactante. Além disso, os valores obtidos apresentaram variações pouco significativas e PDI inferiores a 0,5, o que confere as amostras melhor capacidade de monodispersão e consequentemente melhor estabilidade. 
Tabela 4 - PDI das NPs de QTS/SC, QTS/SC/LECITINA, QTS/SC/CURCUMINA e QTS/SC/LECTINA/CURCUMINA em função da temperatura, durante o período de 90 dias.

\begin{tabular}{|c|c|c|c|c|c|}
\hline \multirow{15}{*}{ 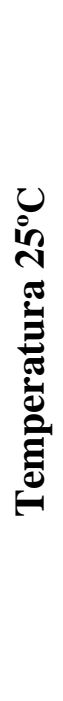 } & Tempo & $\mathrm{QTS}_{\mathbf{S} \mathrm{SC}^{\mathrm{a}}}$ & QTS/SC/LEC ${ }^{\mathrm{a}}$ & QTS/SC/CURC $^{\mathbf{a}}$ & QTS/SC/LEC/CURC ${ }^{\mathrm{a}}$ \\
\hline & 1 & $0,429 \pm 0,02$ & $0,384 \pm 0,02$ & $0,391 \pm 0,02$ & $0,339 \pm 0,02$ \\
\hline & 2 & $0,470 \pm 0,02$ & $0,358 \pm 0,04$ & $0,344 \pm 0,03$ & $0,343 \pm 0,02$ \\
\hline & 3 & $0,314 \pm 0,22$ & $0,230 \pm 0,03$ & $0,418 \pm 0,05$ & $0,397 \pm 0,09$ \\
\hline & 4 & $0,212 \pm 0,08$ & $0,475 \pm 0,08$ & $0,475 \pm 0,04$ & $0,483 \pm 0,01$ \\
\hline & 5 & $0,527 \pm 011$ & $0,509 \pm 0,08$ & $0,539 \pm 0,09$ & $0,391 \pm 0,03$ \\
\hline & 10 & $0,495 \pm 0,01$ & $0,415 \pm 0,15$ & $0,686 \pm 0,22$ & $0,544 \pm 0,04$ \\
\hline & 20 & $0,467 \pm 0,04$ & $0,458 \pm 0,04$ & $0,531 \pm 0,04$ & $0,457 \pm 0,05$ \\
\hline & 30 & $0,504 \pm 0,02$ & $0,554 \pm 0,02$ & $0,525 \pm 0,05$ & $0,316 \pm 0,10$ \\
\hline & 40 & $0,573 \pm 0,02$ & $0,539 \pm 0,05$ & $0,515 \pm 0,03$ & $0,487 \pm 0,09$ \\
\hline & 50 & $0,572 \pm 0,03$ & $0,562 \pm 0,01$ & $0,496 \pm 0,05$ & $0,539 \pm 0,01$ \\
\hline & 60 & $0,405 \pm 0,01$ & $0,430 \pm 0,02$ & $0,433 \pm 0,07$ & $0,490 \pm 0,08$ \\
\hline & 70 & $0,492 \pm 0,05$ & $0,530 \pm 0,02$ & $0,469 \pm 0,05$ & $0,400 \pm 0,09$ \\
\hline & 80 & $0,528 \pm 0,04$ & $0,530 \pm 0,03$ & $0,493 \pm 0,09$ & $0,484 \pm 0,03$ \\
\hline & 90 & $0,503 \pm 0,06$ & $0,476 \pm 0,07$ & $0,436 \pm 0,03$ & $0,544 \pm 0,02$ \\
\hline \multirow{14}{*}{ 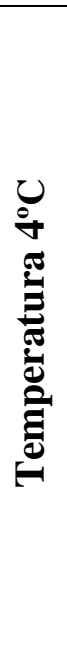 } & 1 & $0,470 \pm 0,04$ & $0,311 \pm 0,03$ & $0,314 \pm 0,02$ & $0,230 \pm 0,08$ \\
\hline & 2 & $0,360 \pm 0,04$ & $0,335 \pm 0,05$ & $0,429 \pm 0,02$ & $0,234 \pm 0,08$ \\
\hline & 3 & $0,413 \pm 0,06$ & $0,382 \pm 0,12$ & $0,458 \pm 0,14$ & $0,431 \pm 0,08$ \\
\hline & 4 & $0,442 \pm 0,03$ & $0,309 \pm 0,03$ & $0,319 \pm 0,17$ & $0,439 \pm 0,05$ \\
\hline & 5 & $0,492 \pm 0,04$ & $0,502 \pm 0,13$ & $0,478 \pm 0,08$ & $0,386 \pm 0,12$ \\
\hline & 10 & $0,517 \pm 0,09$ & $0,544 \pm 0,03$ & $0,564 \pm 0,02$ & $0,378 \pm 0,01$ \\
\hline & 20 & $0,517 \pm 0,03$ & $0,429 \pm 0,02$ & $0,416 \pm 0,01$ & $0,344 \pm 0,06$ \\
\hline & 30 & $0,526 \pm 0,04$ & $0,551 \pm 0,04$ & $0,555 \pm 0,03$ & $0,441 \pm 0,03$ \\
\hline & 40 & $0,574 \pm 0,01$ & $0,531 \pm 0,02$ & $0,421 \pm 0,05$ & $0,558 \pm 0,02$ \\
\hline & 50 & $0,550 \pm 0,01$ & $0,538 \pm 0,04$ & $0,529 \pm 0,05$ & $0,471 \pm 0,03$ \\
\hline & 60 & $0,558 \pm 0,02$ & $0,547 \pm 0,04$ & $0,391 \pm 0,02$ & $0,510 \pm 0,07$ \\
\hline & 70 & $0,533 \pm 0,01$ & $0,536 \pm 0,01$ & $0,512 \pm 0,08$ & $0,408 \pm 0,01$ \\
\hline & 80 & $0,556 \pm 0,06$ & $0,552 \pm 0,02$ & $0,533 \pm 0,03$ & $0,480 \pm 0,08$ \\
\hline & 90 & $0,531 \pm 0,02$ & $0,529 \pm 0,03$ & $0,473 \pm 0,05$ & $0,466 \pm 0,08$ \\
\hline
\end{tabular}

${ }^{\mathrm{a}}$ análise realizada em triplicata, $\mathrm{n}=3$.

Com base nos dados apresentados na Tabela 5, os valores do $\mathrm{pH}$ das amostras com e sem a presença de lecitina retratam pouca variação, mantendo-se praticamente constante ao longo do tempo e independente da temperatura, indicando assim boa estabilidade coloidal. 
Tabela 5 - $\mathrm{pH}$ das NPs de QTS/SC, QTS/SC/LECITINA, QTS/SC/CURCUMINA e QTS/SC/LECTINA/CURCUMINA em função da temperatura, durante o período de 90 dias.

\begin{tabular}{|c|c|c|c|c|c|}
\hline \multirow{29}{*}{ 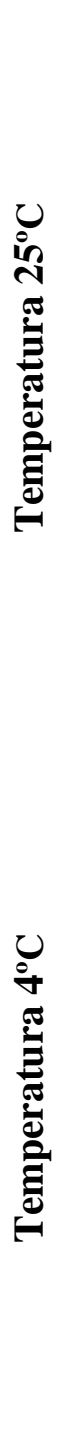 } & Tempo & QTS/SC & QTS/SC/LEC & QTS/SC/CURC & QTS/SC/LEC/CURC \\
\hline & 1 & 4,11 & 4,13 & 4,12 & 4,11 \\
\hline & 2 & 4,18 & 4,20 & 4,26 & 4,15 \\
\hline & 3 & 4,12 & 4,13 & 4,18 & 4,16 \\
\hline & 4 & 4,13 & 4,13 & 4,16 & 4,16 \\
\hline & 5 & 4,11 & 4,00 & 4,13 & 4,08 \\
\hline & 10 & 4,19 & 4,23 & 4,26 & 4,23 \\
\hline & 20 & 4,15 & 4,15 & 4,23 & 4,26 \\
\hline & 30 & 4,16 & 4,13 & 4,18 & 4,20 \\
\hline & 40 & 4,22 & 4,32 & 4,19 & 4,21 \\
\hline & 50 & 4,04 & 4,03 & 4,03 & 4,22 \\
\hline & 60 & 4,15 & 4,12 & 4,16 & 4,21 \\
\hline & 70 & 4,10 & 4,09 & 4,09 & 4,24 \\
\hline & 80 & 4,12 & 4,12 & 4,18 & 4,26 \\
\hline & 90 & 4,17 & 4,22 & 4,11 & 4,17 \\
\hline & 1 & 4,06 & 4,07 & 4,15 & 4,11 \\
\hline & 2 & 4,23 & 4,31 & 4,32 & 4,39 \\
\hline & 3 & 4,23 & 4,22 & 4,32 & 4,23 \\
\hline & 4 & 4,22 & 4,19 & 4,23 & 4,22 \\
\hline & 5 & 4,20 & 4,18 & 4,19 & 4,19 \\
\hline & 10 & 4,26 & 4,37 & 4,23 & 4,35 \\
\hline & 20 & 4,24 & 4,30 & 4,32 & 4,32 \\
\hline & 30 & 4,27 & 4,27 & 4,29 & 4,30 \\
\hline & 40 & 4,23 & 4,22 & 4,28 & 4,25 \\
\hline & 50 & 4,48 & 4,43 & 4,39 & 4,35 \\
\hline & 60 & 4,35 & 4,27 & 4,29 & 4,27 \\
\hline & 70 & 4,42 & 4,35 & 4,32 & 4,32 \\
\hline & 80 & 4,38 & 4,32 & 4,26 & 4,29 \\
\hline & 90 & 4,40 & 4,38 & 4,29 & 4,32 \\
\hline
\end{tabular}

Ao longo do estudo da estabilidade físico-química, foram observadas algumas variações nas características das nanopartículas, não se pode afirmar que a variação de temperatura $\left(4^{\circ} \mathrm{C}\right.$ e $\left.25^{\circ} \mathrm{C}\right)$ teve influência direta nas variações dos parâmetros: diâmetro hidrôdinâmico, potencial zeta e PDI das nanopartículas, pois com relação a essas diferentes temperaturas, as variações sofridas foram pouco significativas. Com base nos parâmetros analisados, verificou-se que as nanopartículas se apresentaram estáveis. Porém, por se tratar de uma suspensão coloidal de nanopartículas, que está mais propensa a agregação e sedimentação no decorrer do tempo, é preciso realizar o acompanhamento destes, e de outros parâmetros, por um período superior ao estabelecido neste estudo. 


\subsection{Eficiência de encapsulação da curcumina às nanopartículas (\%EE)}

A eficiência de encapsulação da curcumina nas nanopartículas de quitosana/sulfato de condroitina, foi calculada com base na relação entre a quantidade de curcumina associada e a quantidade total de curcumina adicionada no preparo das nanopartículas, conforme a equação 1 (item 4.2.5.3), ocorrendo uma variação significante entre os valores obtidos dos diferentes pHs, conforme ilustra a Tabela 6.

Tabela 6 - Eficiência de encapsulação da curcumina em NPs de QTS/SC e QTS/SC/Lecitina.

\begin{tabular}{c|c|c|c}
\hline Amostra & $\begin{array}{c}\text { Curcumina } \\
\text { adicionada }(\mathbf{m g})^{\text {a }}\end{array}$ & $\begin{array}{c}\text { Curcumina } \\
\text { encapsulada (mg) }\end{array}$ & $\begin{array}{c}\text { Eficiência de } \\
\text { encapsulação (\%)EE) }\end{array}$ \\
\hline QTS/SC & $30,7 \pm 0,15$ & $24,2 \pm 0,11$ & $78,6 \pm 0,36 \%$ \\
QTS/SC/Lecitina & $30,7 \pm 0,21$ & $26,8 \pm 0,16$ & $87,5 \pm 0,51 \%$ \\
\hline
\end{tabular}

${ }^{a}$ análise realizada em triplicata, $\mathrm{n}=3$.

Com base nos valores obtidos, é possível observar que o surfactante adicionado no preparo da nanopartículas influência de forma direta na eficiência de encapsulação do fármaco, pois observou-se uma taxa de $87,5 \%$ de curcumina encapsulada nestas nanopartículas. A lecitina é um surfactante biocompatível, que promove melhorias nas propriedades das nanopartículas, bem como um aumento na taxa de incorporação fármaco.

Estudos similares demonstram resultados similares aos obtidos neste estudo. Dandekar et al. (2010b) produziram nanopartículas de curcumina encapsulada em hidrogel de hidroxipropil metil celulose e poli(vinil pirrolidona) pela técnica de miniemulsificação/evaporação do solvente. Os autores encontraram valores de eficiência de encapsulação de $72 \%$, indicando uma baixa afinidade entre a curcumina e os encapsulantes utilizados. Yallapu et al. (2010) encapsulou curcumina em poli(ácido lático-co-glicólico) pela técnica de nanoprecipitação, utilizando estabilizantes como poli(vinil álcool) e poli(L-lisina) e obteve resultados de eficiência de encapsulação entre 49,6 $\pm 4,5 \%$ e 89,5 $\pm 3,2 \%$.

Anitha et al. (2011) produziram curcumina nanoencapsulada em orto-carboximetil quitosana, obtendo partículas de estruturas esféricas com um diâmetro médio de cerca de 150 nm e com eficiência de encapsulação de $87 \%$. Conduziram estudos da atividade de curcumina nanoencapsulada demonstrando efeito tóxico para determinadas células cancerígenas e não tóxicas para células normais. 


\subsection{Avaliação morfológica das nanopartícula}

Para a análise do diâmetro e morfologia das nanopartículas foi utilizada a técnica de Microscopia Eletrônica de Transmissão (MET). Neste estudo, não foram obtidos uma quantidade de perfis com qualidade suficiente para a realização da contagem das nanopartículas.

Para as análises de MET, a suspensão das nanopartículas é gotejada sobre uma tela de cobre e, então desidratada para ser analisada, o que também pode justificar a redução do tamanho das nanopartículas. Com a desidratação a água presente dentro das nanopartículas é eliminada. Provocando uma contração e, consequentemente uma redução no seu tamanho.

O tamanho de todas as nanopartículas obtido por meio da análise de MET foi inferior aos tamanhos encontrados por nas análises de DLS, isto pode está relacionado ao fato de que no microscópio ocorre a visualização de apenas uma população de partículas ou também a formação de aglomerados durante a medida de diâmetro (Figura 20).

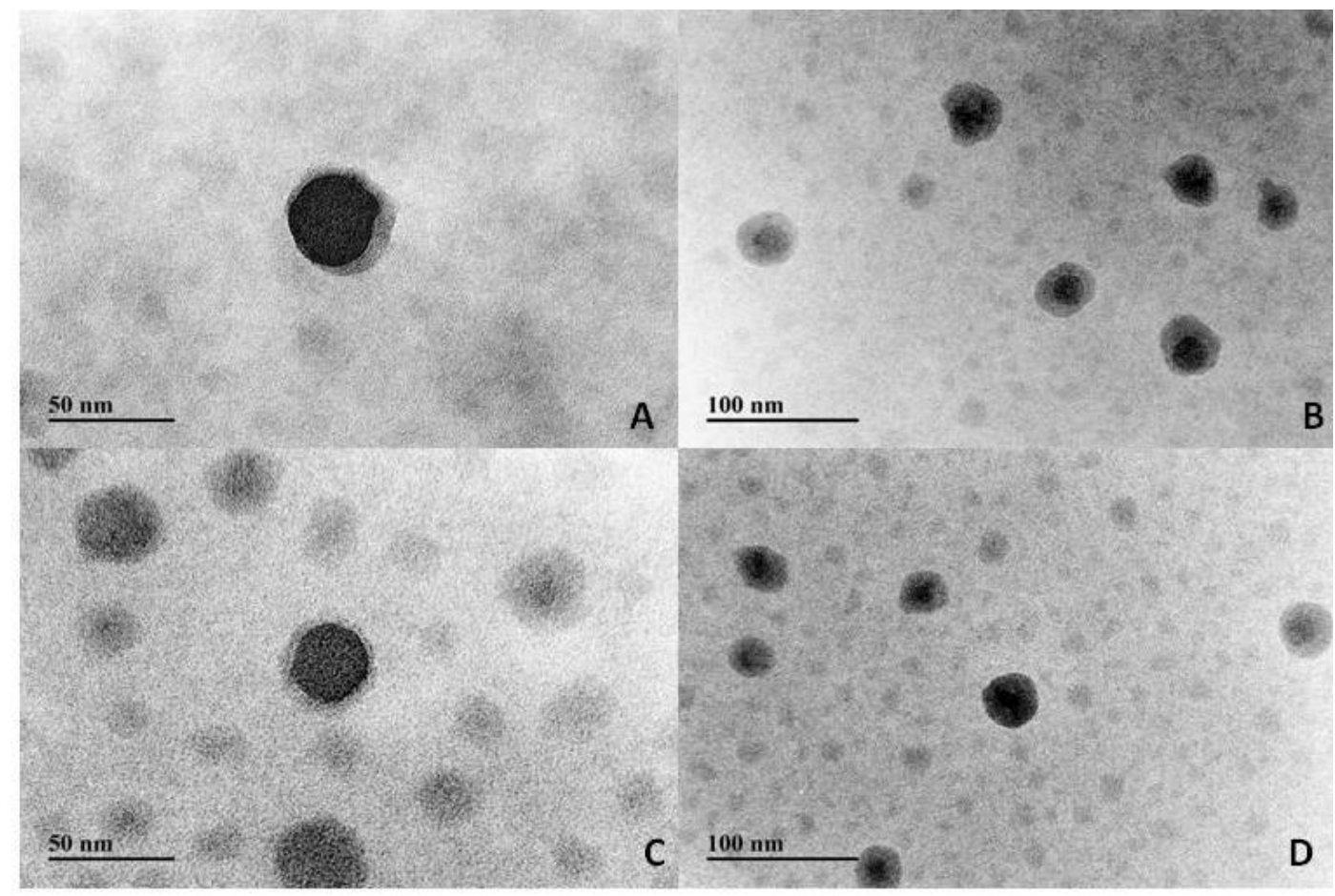

Figura 20 - Microscopia Eletrônica de Transmissão para as amostras: A) QTS/SC (50nm); B) QTS/SC/Curcumina (100nm); C) QTS/SC/Lecitina (50nm) e D) QTS/SC/Lecitina/Curcumina $(100 \mathrm{~nm})$.

As nanopartículas de quitosana / sulfato de condroitina puras e contendo curcumina e/ou lecitina, apresentam em suas microscopias regiões claras e escuras, características essas que indicam a ausência de homogeneidade, ou seja, uma morfologia heterogênea. 
Nas micrografias obtidas das diferentes amostras apresentadas na Figura 20 observa-se a formação de nanopartículas compactas e esféricas, além disso, é possível observar um núcleo sólido envolto em polímero que não interagiu em todas as micrografias. Verificou-se também que a presença do ativo (curcumina) e da lecitina não alterou a morfologia das nanopartículas. As nanopartículas não se apresentaram perfeitamente esféricas nas fotomicrografias, provavelmente em virtude de distorção decorrente da secagem e desidratação no momento do preparo da amostra.

\subsection{Espectroscopia de infravermelho (FTIR)}

O espectro de infravermelho é característico da molécula como um todo. Porém certos grupos de átomos dão origem a bandas que ocorrem mais ou menos na mesma frequência, independente da estrutura da molécula (MILIOLI, 2011). A Figura 21 apresenta o espectro na região infravermelho para os sistemas desenvolvidos neste estudo.

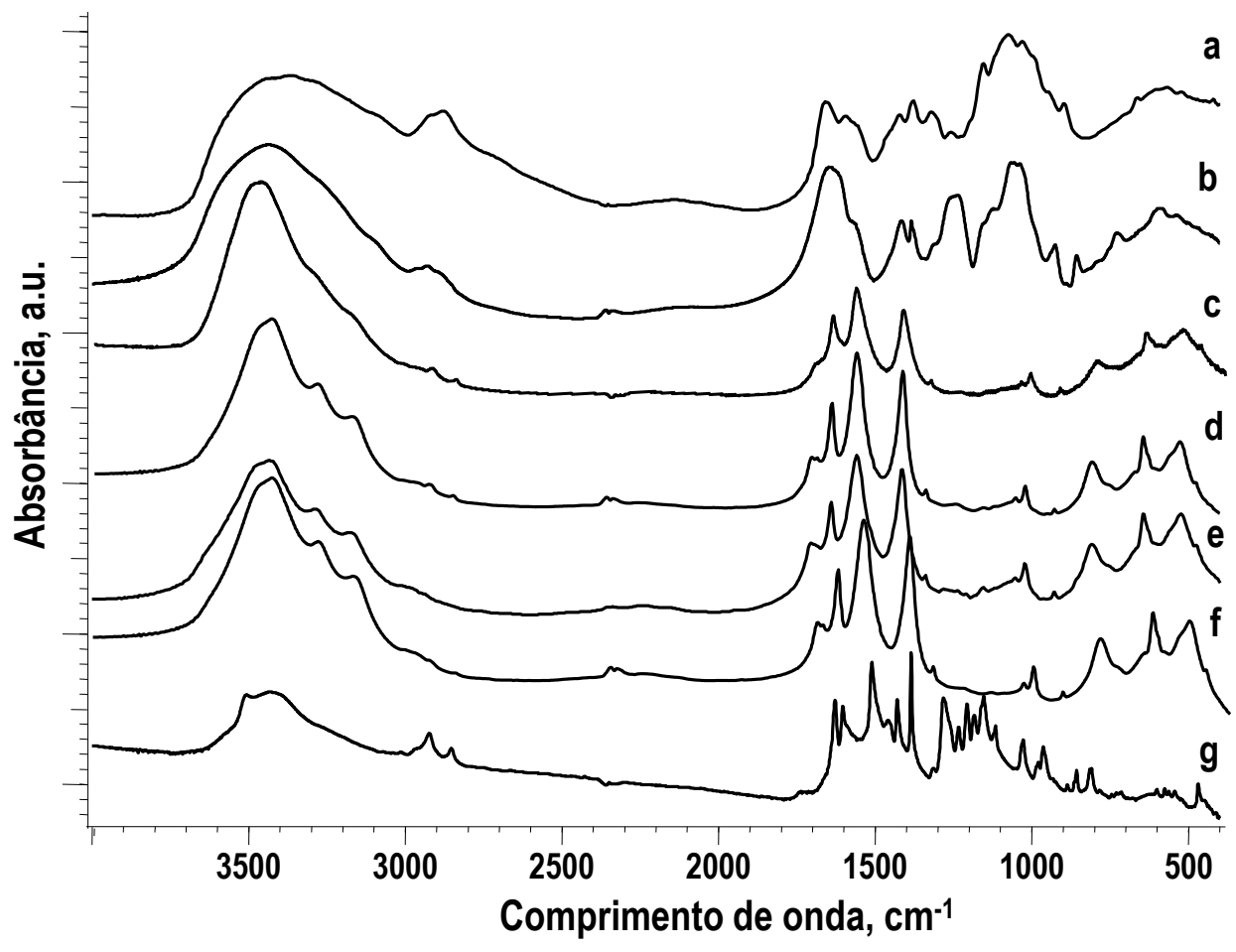

Figura 21- Espectros de FTIR para: a) quitosana; b) sulfato de condroitina; c) nanopartícula de QTS/SC; d) nanopartícula de QTS/SC/Lecitina; e) nanopartícula de QTS/SC/curcumina; f) nanopartícula de QTS/SC/lecitina/curcumina e g) curcumina.

O espectro de quitosana (Figura 22a) pode-se notar a presença de algumas bandas características em $3367 \mathrm{~cm}^{-1}(\mathrm{v}-\mathrm{OH})$, que correspondem ao estiramento axial $\mathrm{OH}$ das 
hidroxilas, banda de amida I (deformação axial C = O) situada em $1658 \mathrm{~cm}^{-1}$ e em $1589 \mathrm{~cm}^{-1}$ banda referente ao grupo $\mathrm{NH}_{2}$. Em $1,377 \mathrm{~cm}^{-1}$ observa-se uma faixa na deformação angular $\mathrm{CH}_{2}$ simétrica.

No espectro do sulfato de condroitina (Figura 22b), evidenciam a presença de bandas em $3441 \mathrm{~cm}^{-1}$, referente à ligação $-\mathrm{OH}$, em $1649 \mathrm{~cm}^{-1}$, referente à amida I, em $1571 \mathrm{~cm}^{-1}$ observou-se à vibração, referente a deformação da amina, em 1238-1060 $\mathrm{cm}^{-1}$ referente ao estiramento da ligação $\mathrm{S}=\mathrm{O}$ e em $856 \mathrm{~cm}^{-1}$ associado a ligação do grupo C-O-S.

No espectro da curcumina (Figura 22g), pode-se observar o espectro da curcumina, que apresenta banda de absorção em $3451 \mathrm{~cm}^{-1}$ referente ao grupo $\mathrm{OH}$ fenólico, em $1620 \mathrm{~cm}-1$ a banda refere-se ao estiramento de $\mathrm{C}=\mathrm{O}$ de cetona conjugada, em 1562 e $1420 \mathrm{~cm}-1$, estiramento de $\mathrm{C}=\mathrm{C}$ de anel aromático e alifático. A banda em1380 cm-1 refere-se ao estiramento dos grupos $\mathrm{CH} 3$ presentes na estrutura do corante e, em $1070 \mathrm{~cm}-1$, estiramento de C-O-C, de éter (PAN et al.,2006).

No espectro das amostras das nanopartículas sintetizada no estudo (Figura 20c), foi observado o aparecimento de uma nova banda em $1020 \mathrm{~cm}^{-1}$ que evidencia o estiramento da ligação entre os grupos $\mathrm{NH}_{3}{ }^{+}-\mathrm{SO}_{3}{ }^{-}$, indicando a interação entre os dois polímeros (RENA et al., 2007). Além disto, observou-se também neste espectro um deslocamento do pico 1658 $\mathrm{cm}^{-1}$, referente à amida I para $1639 \mathrm{~cm}^{-1}$ e que a deformação da amina que no espectro de QTS aparece em $1593 \mathrm{~cm}^{-1}$ e no espectro de SC em $1571 \mathrm{~cm}^{-1}$, no espectro das NPs de QTS/SC esta deformação é representada pelo estiramento em $1559 \mathrm{~cm}^{-1}$, indicando que o grupamento $\mathrm{NH}_{2}$ nas nanopartículas encontra-se na forma de $\mathrm{NH}_{3}{ }^{+}$(YEH et al., 2011).

No espectro da nanopartículas de quitosana / sulfato de condroitina contendo curcumina (Figura 22e), verificou-se que ocorreu um deslocamento da banda em $1593 \mathrm{~cm}^{-1}$ para $1558 \mathrm{~cm}^{-1}$, referente à $\mathrm{NH}_{2}$ da quitosana, indicando a interação entre o grupo amina do polímeros e o grupo fenólico da curcumina (PAN et al., 2006).

Para as amostras contendo o surfactante lecitina observa-se o surgimento de bandas em 3284 e $3171 \mathrm{~cm}^{-1}$ referentes aos estiramentos do grupamento amina presentes no surfactante. Adicionalmente observa-se na Figura 22d e Figura 22f o surgimento de uma nova banda em $1705 \mathrm{~cm}^{-1}$ referente à carbonila dos ácidos graxos da lecitina. Desta forma observase que o surfactante está disperso em toda amostra e auxilia na dispersão da curcumina nas nanopartículas. Esses dados indicam que a curcumina está ligada a quitosana via ligação de hidrogênio, onde os $\mathrm{OH}$ fenólicos dela se interagem com os grupos amino da quitosana. 


\subsection{Análise Termogravimétrica (TGA)}

As curvas termogravimétricas para os polímeros, para as nanopartículas formadas por meio deles, e para a curcumina, na Figura 22, onde são observados os perfis de perda de massa.

A curva de perda de massa para a quitosana exibe um comportamento típico para este polissacarídeo, apresentando dois estágios distintos de perda de massa, apresentando um em $73^{\circ} \mathrm{C}$, relacionado com a desimudificação do polímero e outro em $305^{\circ} \mathrm{C}$, que é atribuído a degradação térmica do biopolímero, via a quebra das ligações glicosídicas existentes em sua estrutura.
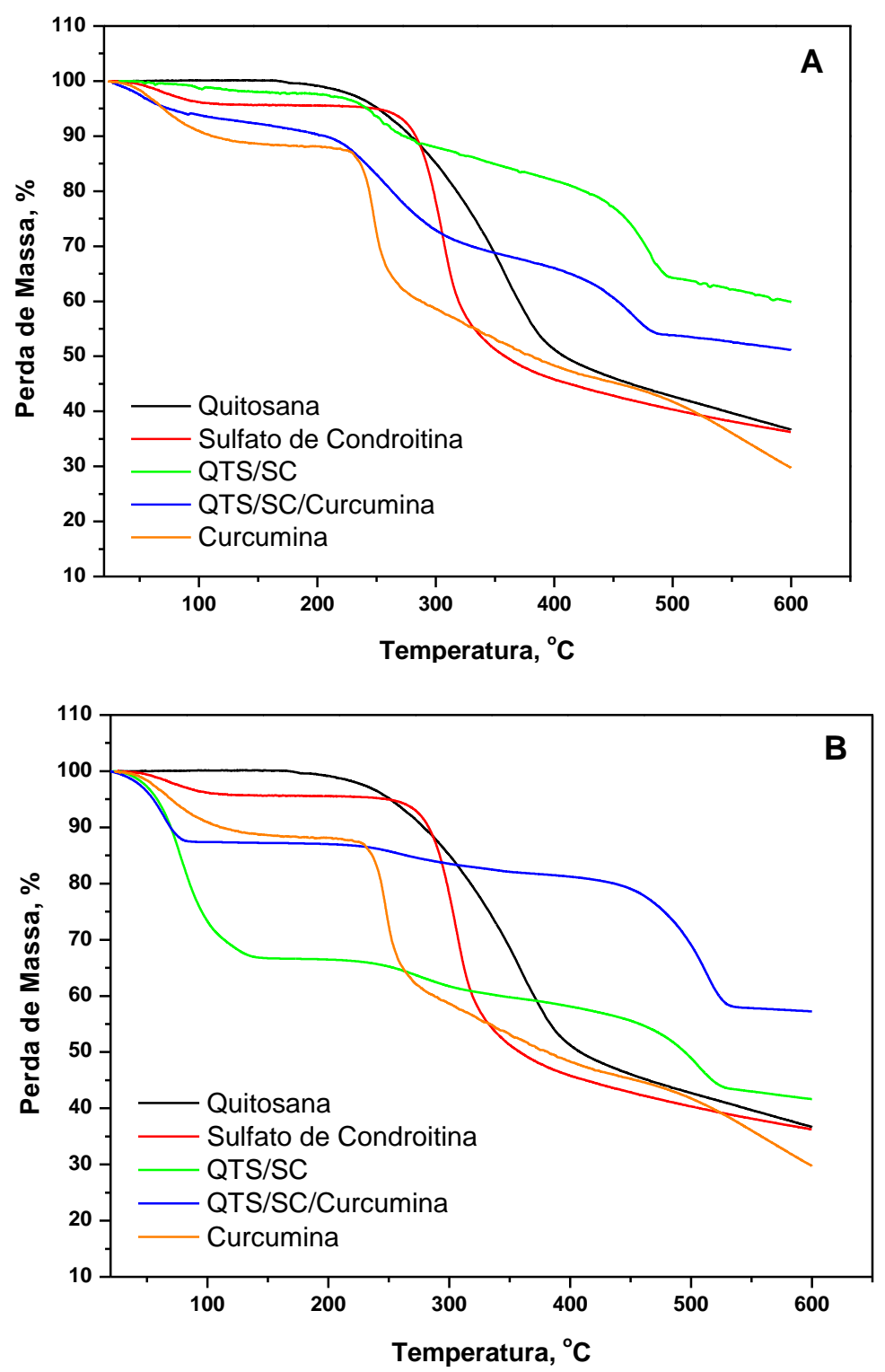

Figura 22: Analise termogravimétrica para os materiais usados na produção das nanopartículas, nos sistemas puros (A) e nos sistemas contendo lecitina (B). 
Para o sulfato de condroitina, observam-se três estágios de perda de massa. O primeiro em $76,25^{\circ} \mathrm{C}$, refere-se desumidificação do biopolímero, que ocorre devido a perda de agua. $\mathrm{O}$ segundo e o terceiro estágios, relacionados com a degradação do biopolímero ocorrem em $248,4^{\circ} \mathrm{C}$ com e $567,8^{\circ} \mathrm{C}$, respectivamente.

Para as nanopartículas de quitosana / sulfato de condroitina puras, foram observados, também, três estágios de perda de massa. O primeiro e o segundo estágio são representados pelos picos $125,6^{\circ} \mathrm{C}$ e $247,3^{\circ} \mathrm{C}$, indicando a perda de moléculas de água. A terceira perda de massa ocorreu em $458,6^{\circ} \mathrm{C}$ atribuído à degradação da nanopartícula.

Para o sulfato de condroitina, observam-se três estágios de perda de massa. O primeiro em $76,25^{\circ} \mathrm{C}$, refere-se desumidificação do biopolímero, que ocorre devido a perda de agua. $\mathrm{O}$ segundo e o terceiro estágios, relacionados com a degradação do biopolímero ocorrem em $248,4^{\circ} \mathrm{C}$ com e $567,8^{\circ} \mathrm{C}$, respectivamente.

Para as nanopartículas de quitosana / sulfato de condroitina puras, foram observados, também, três estágios de perda de massa. O primeiro e o segundo estágio são representados pelos picos $125,6^{\circ} \mathrm{C}$ e $247,3^{\circ} \mathrm{C}$, indicando a perda de moléculas de água. A terceira perda de massa ocorreu em $458,6^{\circ} \mathrm{C}$ atribuído à degradação da nanopartícula.

Com base nos resultados apresentados, foi possível observar que as nanopartículas de quitosana / sulfato de condroitina apresentaram uma maior estabilidade térmica quando comparado aos polímeros que as constituem, pois as mesmas necessitaram de uma temperatura mais elevada para se degradar. Isto pode ser comprovado devido à forte interação eletrostática entre os dois biopolímeros, provocando uma menor perda de massa no segundo estágio, e o reordenamento dos polímeros. As regiões ordenadas, formadas pelo reordenamento das cadeias de QTS e das cadeias de SC remanescentes, aumentam a estabilidade térmica das nanopartículas. Assim, após a reordenação da rede polimérica, a degradação do material ocorre em temperatura mais elevada (Figura 23A - curva verde). (FAJARDO, 2009; DU et al., 2006). Porém ao ser adicionado o surfactante lecitina, percebese que a estrutura polimérica formada é modificada, e a estabilidade térmica é alterada.

Para as NPs de QTS/SC/Curcumina sem a presença de lecitina, os perfis de degradação apresentaram-se com três estágios de perda de massa, sendo que o primeiro e o segundo ocorreram em $59^{\circ} \mathrm{C}$ e $256^{\circ} \mathrm{C}$, respectivamente, indicando a evaporação da água, o terceiro estágio de perda de massa ocorreu em $422,7^{\circ} \mathrm{C}$, correspondente à decomposição dos polímeros. Além disso, observou-se que há um deslocamento do pico de degradação da NPs de QTS/SC pura em $458,6^{\circ} \mathrm{C}$ para $422,7^{\circ} \mathrm{C}$ nas NPs de QTS/SC/Curcumina. O deslocamento deste pico de degradação sugere a presença de outro material nas nanopartículas, provocando 
uma diminuição na estabilidade térmica dos polímeros (NETO et al., 2005; ZOHURIAN et al., 2004).

Quando a surfactante lecitina é adicionado as QTS/SC/Curcumina, observa-se que o perfil de perda de massa ainda possui três estágios de perda de massa, porem a estabilidade térmica é aumentada. O primeiro e o segundo, referentes a perda de umidade e de água ligada a estrutura do polímero ocorrem em $62^{\circ} \mathrm{C}$ e $256^{\circ} \mathrm{C}$, respectivamente. Um terceiro pico é observado em $512^{\circ} \mathrm{C}$ evidenciando que a estrutura formada entre os dois biopolimeros mais o surfactante na presença da curcumina, aumentam a estabilidade térmica da amostra (Figura 23B - curva azul) .

Para a curcumina foram observados três estágios de perda de massa. O primeiro ocorreu em $67^{\circ} \mathrm{C}$ correspondente à perda de moléculas de água e o segundo e terceiro em $252^{\circ} \mathrm{C}$ e $402^{\circ} \mathrm{C}$, respectivamente, referentes à decomposição da curcumina.

\subsection{Perfil de liberação da curcumina}

O estudo de liberação controlada da curcumina encapsulada nas nanopartículas de QTS/SC e QTS/SC/Lecitina, foi conduzido em solução fosfato em pH 6,8 e está apresentado na Figura 23.

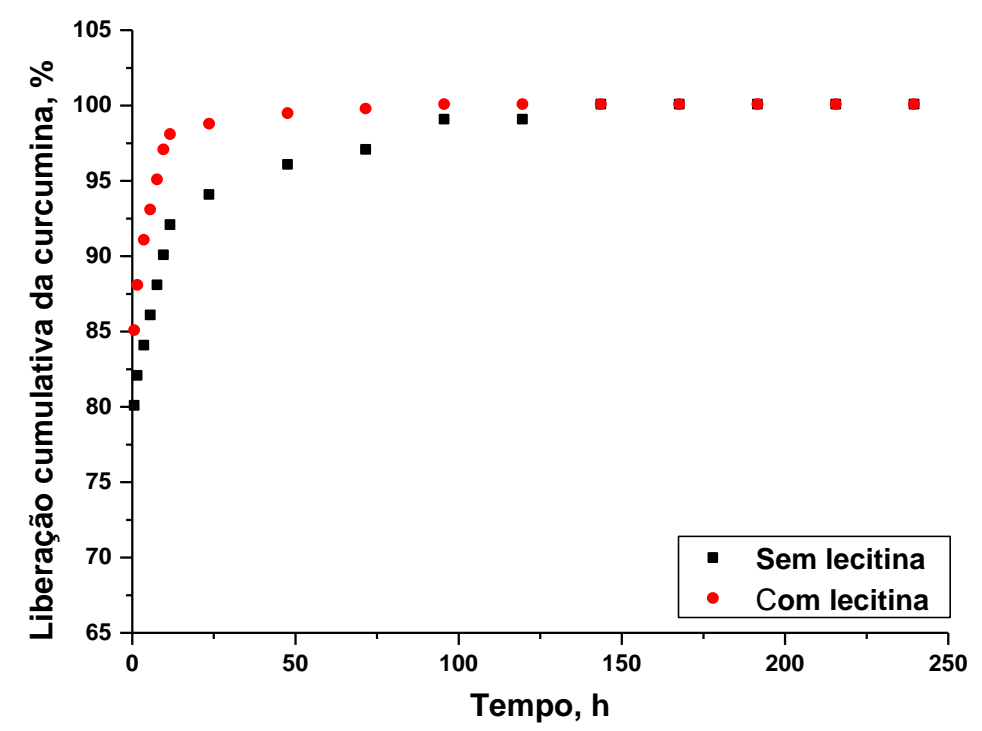

Figura 23 - Liberação controlada de curcumina a partir de NPs de QTS/SC e QTS/SC/Lecitina em solução fosfato em pH 6,8. 
Atualmente, os sistemas poliméricos de liberação de drogas estão sendo amplamente utilizados, estes permitem uma liberação lenta e gradual da substância ativa, além de possibilitar o direcionamento a alvos específicos do organismo (MULLER et al., 2009).

Por intermédio de matrizes hidrofílicas, a liberação de ativos tem sido comprovada como uma interação complexa entre intumescimento, difusão, erosão e relaxação (HARLAND et al., 1988). Portanto, na prática, matrizes poliméricas, geralmente, liberam o soluto via combinação de vários mecanismos. A penetração gradual de água em um polímero ocasiona um aumento gradual no tamanho do mesmo com a formação de um gel hidratado, permitindo que qualquer material aprisionado no polímero possa dissolver-se através do mesmo (PEPPAS e SAHLIN, 1989; MUNDAY e COX, 2000).

A equação 7 é, frequentemente, é utilizada para analisar o processo de liberação de solutos, a fim de caracterizar o mecanismo predominante durante a liberação (KORSMEYER et al., 1983):

$$
\frac{M_{t}}{M_{\infty}}=k \cdot t^{n}
$$

onde $\mathbf{M}_{\mathbf{t}} / \mathbf{M}_{\infty}$ representa a fração do soluto liberado no tempo $\mathbf{t}$, $\mathbf{k}$ é uma constante que incorpora características da matriz polimérica e do soluto e n é o coeficiente difusional, cujo valor depende da geometria da partícula e fornece informações sobre o mecanismo de liberação de agentes ativos a partir de matriz polimérica, Tabela 7 (RITGER e PEPPAS, $1987 a)$

Tabela 7 - Relação entre o expoente difusional $\boldsymbol{n}$ e mecanismo de liberação para os diferentes sistemas de liberação controlada.

\begin{tabular}{cccc}
\hline \multicolumn{3}{c}{ Expoente difusional, $\mathbf{n}$} & Mecanismo de liberação \\
\cline { 1 - 3 } Filmes & Cilindros & Esferas & Difusão Fickiana \\
0,5 & 0,45 & 0,43 & Transporte anômalo (não Fickiano) \\
$0,5<\mathrm{n}<1,0$ & $0,45<\mathrm{n}<0,89$ & $0,43<\mathrm{n}<0,85$ & \\
1,0 & 0,89 & 0,85 & Caso II de transporte \\
$>1,0$ & $>0,89$ & $>0,85$ & Super Caso II de transporte \\
\hline
\end{tabular}

Fonte: RITGER e PEPPAS, 1987a; SIEPMANN e PEPPAS, 2001.

Baseando-se nos critérios para cinética de liberação de solutos a partir de sistemas intumescíveis com geometria esférica, um valor de coeficiente difusional $n \leq 0,43$, indica que 
o mecanismo de liberação observado é o de difusão do soluto através de camadas da matriz, também conhecido como mecanismo de liberação Fickiano ou "Caso I". Quando o coeficiente se encontra entre $0,43<\mathrm{n}<0,85$, obtém-se um transporte não-Fickiano ou anômalo, onde ocorre a superposição dos dois fenômenos, sendo que a liberação é controlada pela difusão e intumescimento, simultaneamente. Um valor de $n=0,85$, indica que a liberação do soluto é controlada apenas pelo intumescimento/relaxação da cadeia polimérica, isto é, independente do tempo, mecanismo este, também conhecido como "Caso II" de transporte. Para valores de n > 0,85 têm-se um Super Caso II de transporte, no qual ocorre a contribuição simultânea de processos como difusão, intumescimento, relaxação e erosão da matriz polimérica (RITGER e PEPPAS, 1987a e 1987b; ROY E ROHERA, 2002; SIEPMANN e PEPPAS, 2001).

A liberação por solvente é baseada na solubilização do agente encapsulante (tipicamente com água) seguindo por subsequente liberação do ingrediente encapsulado. Neste caso, ela pode ser ocasionada por um ruptura repentina ou uma liberação lenta, através do controle de solubilização da parede ou do intumescimento do agente encapsulante, cujo responsáveis são os efeitos do $\mathrm{pH}$ e as mudanças na força iônica do meio (WHORTON, 1995).

A liberação por difusão é estritamente governada por propriedades químicas e físicas do agente encapsulante, tais como, a estrutura da matriz e o tamanho dos poros (WHORTON, 1995). A difusão é regida por um gradiente de concentração e de forças atrativas intermoleculares, por meio de propriedades químicas e físicas do agente encapsulante, tais como: estrutura da matriz e tamanho dos poros (REINECCIUS e WHORTON, 1995). Outro fator que influencia a difusão de um soluto é o grau de intumescimento da microesfera, que pode ser causado pela adsorção de água, ou outro solvente, provocando o aumento dos poros e dos espaços livres, permitindo a permeação do material microencapsulado, através das cadeias poliméricas (SANTOS et al., 2000). Assim, quando ocorre o intumescimento, o agente encapsulante que protege a microesfera passa de um estado vítreo para a forma de um gel. A cadeia polimérica no estado gel, torna-se mais móvel do que no estado vítreo, permitindo que o ingrediente ativo difunda através da matriz mais rapidamente (POTHAKAMURY e BARBOSA-CANOVÁS, 1995). Desta forma, aumentando a atividade da água ou adicionando agentes plastificantes na matriz de um agente encapsulante, aumenta-se a razão da liberação do ingrediente encapsulado (REINECCIUS e WHORTON, 1995).

A partir da linearização da equação $7(\ln \mathrm{Mt} / \mathrm{M} \infty=\ln \mathrm{k}+\mathrm{n} \cdot \operatorname{lnt})$, consegue-se dois importantes parâmetros cinéticos para a liberação da curcumina a partir das nanopartículas. O coeficiente linear nos fornece a constante de velocidade liberação da curcumina $(\mathrm{k})$ a partir 
das NPs e o coeficiente angular nos fornece o expoente difusional $\mathrm{n}$, que caracteriza o mecanismo de liberação da curcumina a partir das NPs sintetizadas neste estudo. Os dados referentes a linearização das curvas de liberação estão apresentados na Tabela 8 e os dados cinéticos e a análise do mecanismo estão apresentados na Tabela 9.

Tabela 8 - Dados referente a linearização das curvas de liberação $(y=a+b x)$ para determinação do mecanismo de liberação da curcumina

\begin{tabular}{c|c|c|c}
\hline Amostra & $\mathbf{a}$ & $\mathbf{b x}$ & Índice de correlação $\left(\mathbf{r}^{2}\right)$ \\
\hline QTS/SC & 3,6807 & $0,126 \mathrm{x}$ & 0,9907 \\
\hline QTS/SC/Lecitina & 3,8969 & $0,104 \mathrm{x}$ & 0,9982 \\
\hline
\end{tabular}

Tabela 9 - Dados cinéticos e análise do mecanismo de liberação

\begin{tabular}{c|c|c}
\hline Amostra & $\mathbf{k}\left(\mathbf{m o l ~ L}^{-1} \mathbf{h}^{-1}\right)$ & Coeficiente Difusional $\boldsymbol{n}$ \\
\hline QTS/SC & 39,67 & 0,126 \\
\hline QTS/SC/Lecitina & 49,24 & 0,104 \\
\hline
\end{tabular}

A partir da Tabela 9 observa-se que a constante de velocidade de liberação é maior para as NPs QTS/SC/Lecitina. A presença de lecitina favorece a liberação do ativo quando as NPs estão em contato com a solução tampão. Em ambas as amostras o coeficiente difusional $n$ tem seu valor menor de 0,45 , o que caracteriza o mecanismo de liberação da curcumina através das NPS por difusão fickiana.

Os grupos amina da quitosana permanecem desprotonados em $\mathrm{pH}$ 6,8, uma vez que o $\mathrm{pH}$ do meio é maior que o pKa do polímero, diminuindo, desta forma, a força de interação existente entre as cadeias de quitosana e sulfato de condroitina. Por outro lado, os grupos sulfônicos e carboxílicos do sulfato de condroitina, com pKa 2,60 e 4,57 respectivamente, tornam-se desprotonados e carregados negativamente. A partir daí, ocorre um aumento na densidade de cargas negativas, o que promove a repulsão eletrostática entre as cadeias do biopolímero sulfato de condroitina. Esta repulsão, associada à diminuição da força de interação entre as cadeias da QTS e SC, desestabiliza a rede polimérica, provocando a expansão desta, e em consequência disso, as moléculas de curcumina associadas ás nanopartículas adquirem maior mobilidade, facilitando assim sua difusão por meio das nanopartículas (FAJARDO, 2009, PIAI et al, 2009). 


\subsection{Avaliação da atividade citotóxica in vitro da curcumina livre e nanoencapsulada}

O potencial terapêutico da curcumina, como um agente citotóxico, tem sido amplamente discutido na literatura. Recentemente, vários estudos tem reportado que a curcumina apresenta perfis de citotoxicidade distintos, conforme o tecido celular e a concentração deste fotoquímico.

Desta forma, ao analisar o efeito da curcumina livre na viabilidade de células MCF-7, no período de 24 h, Figura 25, observou-se que a presença de $10 \mu \mathrm{mol} . \mathrm{L}^{-1}$ de curcumina não houve redução significativamente na viabilidade de células MCF-7. Nas concentrações de 20 e $40 \mu \mathrm{mol} . \mathrm{L}^{-1}$ verificou-se que a curcumina livre reduz significativamente a viabilidade celular para 52,0 e 27,7\% ( $<<0,001)$, respectivamente quando comparado ao grupo controle.

Para a curcumina encapsulada nas NPs de QTS/SC e QTS/SC/Lecitina, Figura 25 observou-se também que não houve redução significativa na viabilidade na concentração de $10 \mu \mathrm{mol} . \mathrm{L}^{-1}$ no período de $24 \mathrm{~h}$. Nas concentrações de 20 e $40 \mu \mathrm{mol} . \mathrm{L}^{-1}$ observou-se que houve diferença estatisticamente significativa. Células MCF-7 tratadas com as NPs de QTS/SC/Curcumina tiveram sua viabilidade reduzida para 55,7 \% (p<0,0001) na concentração de $20 \mu$ mol. $\mathrm{L}^{-1}$ e na concentração de $40 \mu \mathrm{mol} . \mathrm{L}^{-1}$ para 53,4 \% (p<0,0001). Já as NPs de QTS/SC/Lecitina/Curcumina reduziram para 66,7 e 41,4 \% (p<0,0001) nas concentrações de 20 e $40 \mu \mathrm{mol} . \mathrm{L}^{-1}$, respectivamente a viabilidade celular quando comparadas ao grupo controle, no período de 24 h, conforme mostrado na Figura 24.

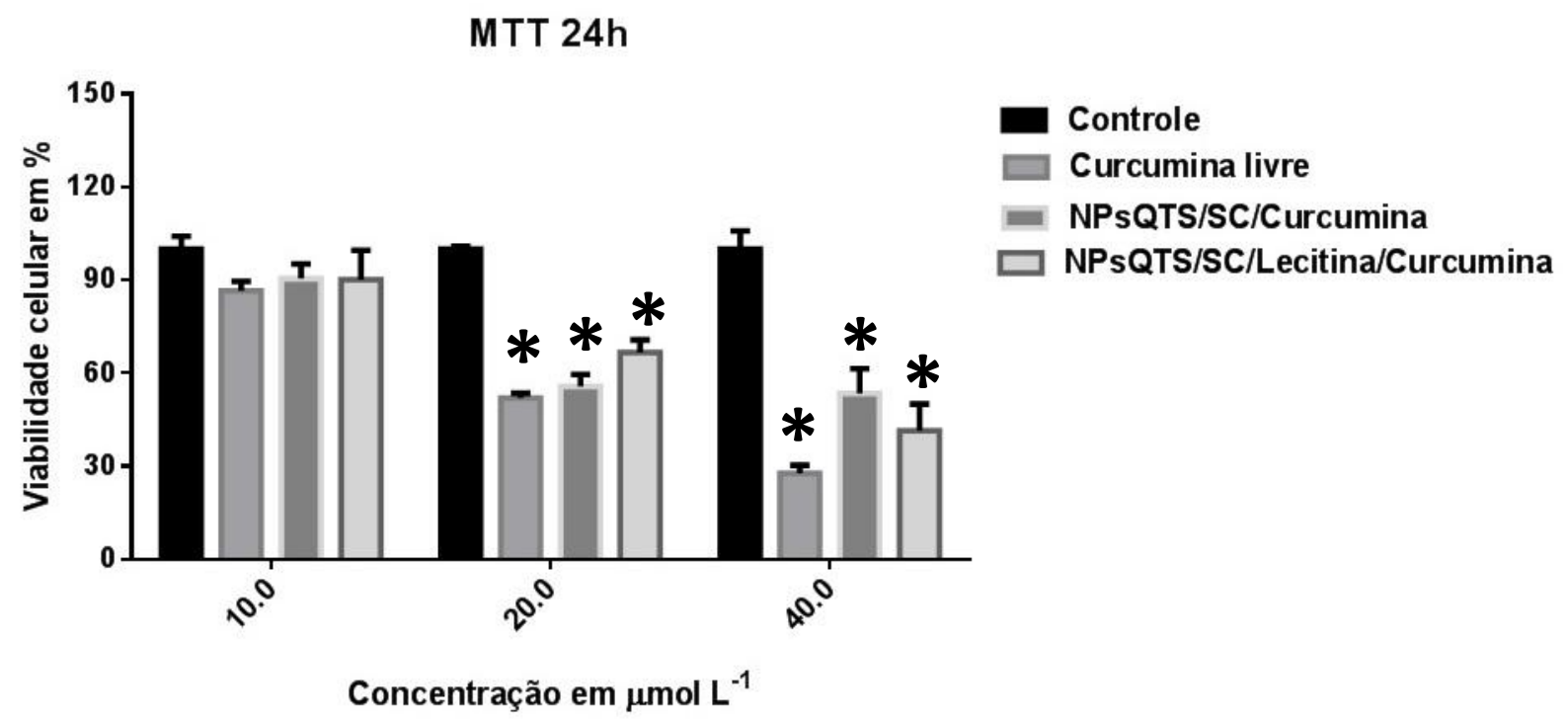

Figura 24 - Avaliação da atividade citotóxica in vitro da curcumina livre e encapsulada em NPs de QTS/SC e QTS/SC/Lecitina no período de 24h ( $<$ < 0.001). Fonte: Autoria própria. 
Para a curcumina livre, Figura 25, foi observado uma redução estatisticamente significativa na viabilidade celular no período de 48 horas em todas as concentrações estudadas. Nas concentrações de 10, 20 e $40 \mu \mathrm{mol} . \mathrm{L}^{-1}$ foi observado que a curcumina livre reduziu para 66,8; 40,5 e 21,8\% (p<0,0001), respectivamente, a viabilidade da célula MCF-7, quando comparado ao grupo controle.

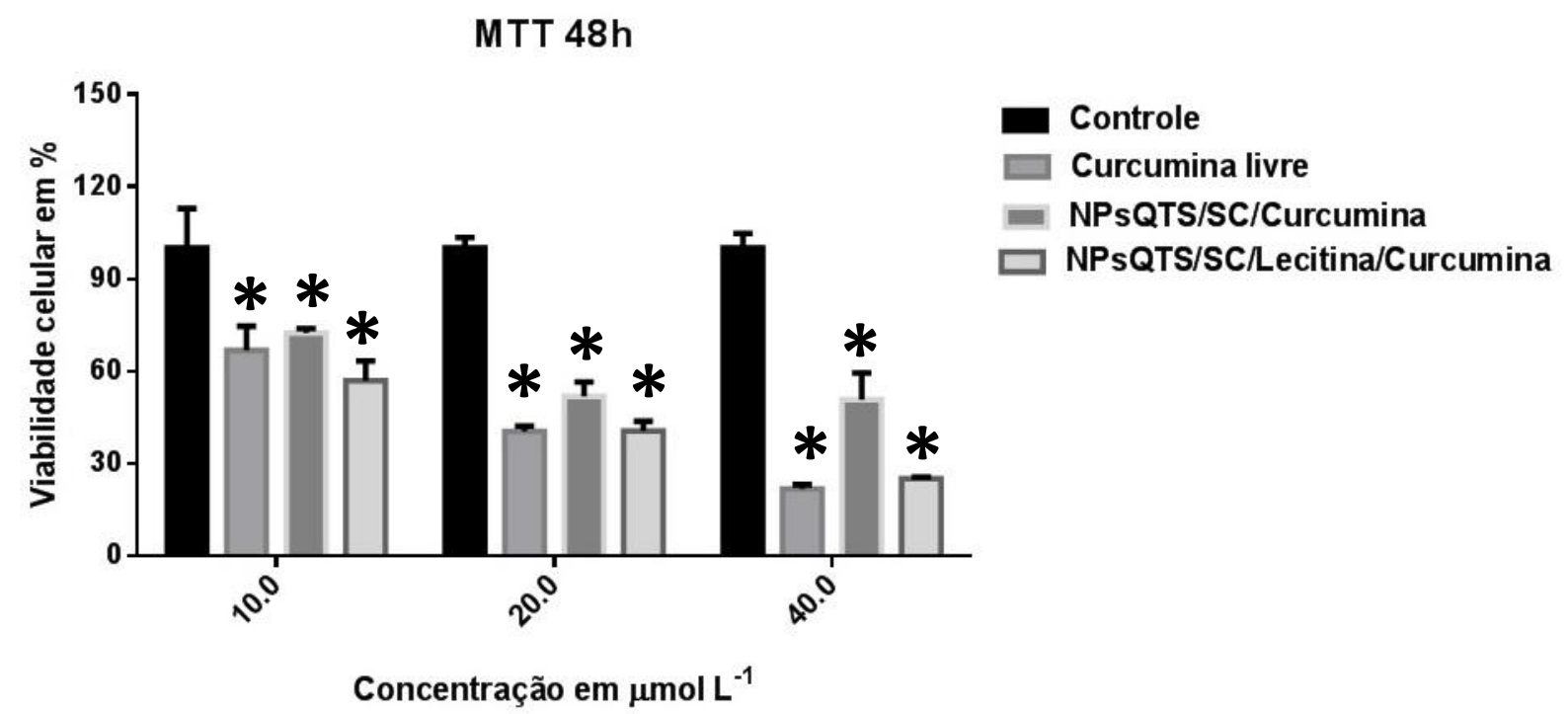

Figura 25 - Avaliação da atividade citotóxica in vitro da curcumina livre e encapsulada em NPs de QTS/SC e QTS/SC/Lecitina no período de 48h (p < 0.001). Fonte: Autoria própria.

As NPs de QTS/SC/Curcumina e QTS/SC/Lecitina/curcumina também apresentaram diferença estatisticamente significativa na viabilidade da célula MCF-7 em todas as concentrações estudadas, no período de 48 h, conforme mostrado na Figura 26. Para as NPs de QTS/SC/Curcumina observou-se que nas concentrações de 20 a $40 \mu \mathrm{mol} . \mathrm{L}^{-1}$ houve redução de $(51,8$ e 50,8 \%, respectivamente; $\mathrm{p}<0,0001)$ e na concentração de $10 \mu$ mol. $L^{-1}$ observou-se uma redução de $72,4 \% \quad(\mathrm{p}<0,001)$ na viabilidade celular. As NPs de QTS/SC/Lecitina/Curcumina reduziram para 25,0. 40,6 e 56,9\% (p<0,0001) a viabilidade das células nas concentração de 40, 20 e $10 \mu \mathrm{mol} . \mathrm{L}^{-1}$, respectivamente, quando comparadas ao grupo controle.

$\mathrm{Na}$ avaliação da viabilidade celular no período de 72 horas da curcumina livre e nanoencapsulada, Figura 26, foi observado uma redução estatisticamente significativa na viabilidade celular em todas as concentrações avaliadas. Para as curcumina livre observou-se que a viabilidade celular foi reduzida para 51,2; 25,3 e 19,2\% (p<0,0001) quando utilizado as concentrações de 10, 20 e $40 \mu \mathrm{mol} . \mathrm{L}^{-1}$, respectivamente para as NPs de QTS/SC/Curcumina foi observado que a viabilidade das células reduziu para 60,6; 43,3 e 36,4\% (p<0,0001) nas 
concentrações de 10, 20 e $40 \mu \mathrm{mol} . \mathrm{L}^{-1}$, respectivamente. Em relação às NPs de QTS/SC/Lecitina/curcumina observou-se que nas concentrações de 10, 20 e $40 \mu \mathrm{mol} . \mathrm{L}^{-1}$ a viabilidade das células MCF-7 foi reduzida para 49,2; 38,9 e 23,8 \% (p<0,0001), respectivamente quando comparado ao grupo controle.

\section{MTT 72h}

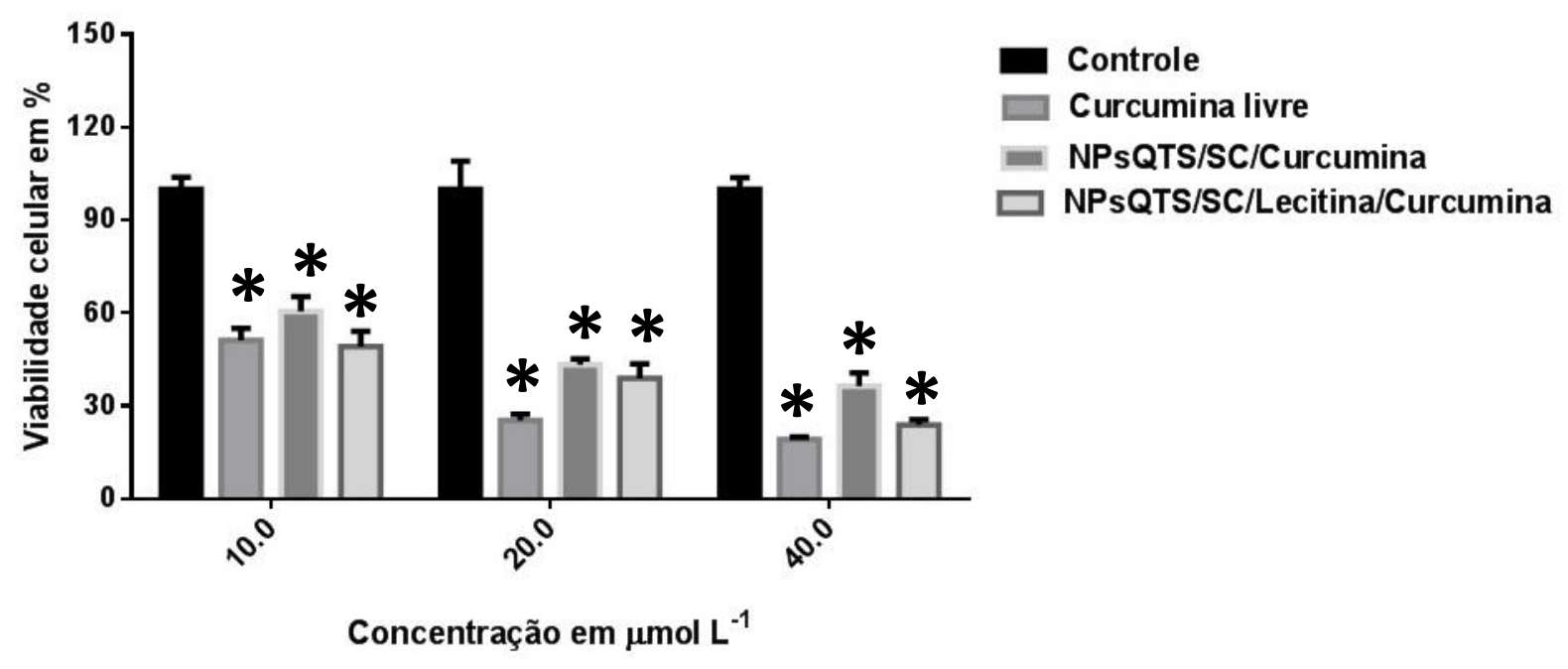

Figura 26 - Avaliação da atividade citotóxica in vitro da curcumina livre e encapsulada em NPs de QTS/SC e QTS/SC/Lecitina no período de 72h ( $<$ < 0.001). Fonte: Autoria própria.

Estes resultados podem estar relacionados ao maior o tempo de incubação, a eficiência de encapsulação da curcumina nas nanopartículas e ao perfil de liberação da curcumina através das NPs, pois em NPs de QTS/SC/Lecitina, observou-se maior eficiência de encapsulação da curcumina, bem como uma liberação mais rápida do ativo.

Nos experimentos controle realizados para se avaliar a toxicidade do sistema de liberação sem a presença da curcumina nos períodos de 24, 48 e 72 horas, observou-se que a adição das NPs de QTS/SC e QTS/SC/Lecitina padrão e dos controles (SC, solução de ácido acético, solução de lecitina/água e solução de etanol/água) não alterou a viabilidade das células e principalmente que estes não apresentaram toxicidade.

Além disso, através do ensaio de viabilidade celular, usando o teste de MTT realizado neste estudo pôde-se verificar que a curcumina livre e encapsulada em nanopartículas de QTS/SC e QTS/SC/Lecitina apresenta efeito citotóxico para as células tumorais humana de mama (MCF-7), pois inibiram o crescimento celular de forma significativa.

Dados obtidos na literatura quanto a aplicação da curcumina na viabilidade celular de linhagens MCF-7, suportam os dados obtidos no estudo, mostrando perfis de viabilidade celular similares aos encontrados neste estudo. Ainda são poucos os estudos que mostram a 
curcumina associada à nanoparticulas (BAYOMI, et al., 2013; BOZTAS, et al., 2013; ZHIDONG, et al., 2014; ZHOU, et al., 2011). 


\section{CONSIDERAÇÕES FINAIS}

Com base nos resultados obtidos neste estudo, observou-se que o método utilizado para a preparação das nanopartículas de QTS/SC e QTS/SC/curcumina na presença e ausência da lecitina, aliado ao estudo de especiação possibilitou a obtenção de nanopartículas com distribuição estreita $(0,339 \pm 0,02$ a $0,429 \pm 0,02)$, diâmetro hidrodinâmico reduzido $(319,0 \pm$ $16,5$ a 415,5 $\pm 6,3)$ e potencial zeta positivo com valor em módulo alto ( $+58,2 \pm 2,5$ a $+64,8 \pm$ $0,2)$, indicando boa estabilidade coloidal.

Atualmente, existem vários métodos descritos para a determinação do grau de desacetilação da quitosana, neste estudo, a medida foi realizada por meio de titulação condutimétrica em função da sua precisão e simplicidade. A porcentagem dos grupos amina livre obtida foi de 76,90\%, o que demonstra que o polímero estudado é de fato a quitosana.

Com a finalidade de caracterizar a substância ativa, curcumina, utilizou-se a técnica UV-vis. A análise foi realizada em solução 2,71 mmol.L $\mathrm{L}^{-1} \mathrm{em} \mathrm{pH} \mathrm{4,0.} \mathrm{Observou-se} \mathrm{que} \mathrm{neste}$ $\mathrm{pH}$ a curcumina apresentou-se protonada e com $\lambda_{\text {máx }}$ igual a $429 \mathrm{~nm}$.

As nanopartículas de QTS/SC e QTS/SC/Lecitina padrão e contendo curcumina, durante o período de 90 dias apresentaram estabilidade físico-química nas diferentes temperaturas de acondicionamento $\left(4^{\circ} \mathrm{C}\right.$ e $\left.25^{\circ} \mathrm{C}\right)$, com variações pouco significativas dos parâmetros pré-estabelecidos: diâmetro hidrodinâmico, PDI, potencial zeta e pH.

A eficiência de encapsulação da curcumina nas NPs QTS/SC e QTS/SC/Lecitina foi de $78,6 \pm 0,36 \%$ a $87,5 \pm 0,51 \%$, respectivamente, o que demonstra que a adição do surfactante nas nanopartículas influência de forma direta na encapsulação do fármaco, uma vez que a adição de lecitina as nanopartículas, aumenta a possibilidade de encapsulação de fármacos hidrofóbicos.

Por meio da análise de microscopia eletrônica de transmissão das diferentes amostras estudadas observou-se a formação de nanopartículas compactas e esféricas. Observou-se ainda que a presença da curcumina e da lecitina não alterou a morfologia das nanopartículas. Além disso, nanopartículas não se apresentaram perfeitamente esféricas nas fotomicrografias, provavelmente devido à distorção decorrente da secagem e desidratação no momento do preparo da amostra.

Por meio da análise das curvas termogravimétricas pôde-se observar que as nanopartículas apresentaram maior estabilidade térmica do que seus polímeros constituintes, além disso a degradação das mesmas só ocorreu em temperaturas elevadas. 
A liberação da curcumina foi conduzida em solução fosfato em pH 6,8, e ocorreu de forma lenta e gradual por meio das nanopartículas, via mecanismo de difusão Fickiana, observando uma liberação de forma mais rápida nas amostras que contem o surfactante.

Através do ensaio de viabilidade celular, usando o teste de MTT realizado neste estudo pôde-se verificar que a curcumina livre e encapsulada em NPs de QTS/SC e QTS/SC/Lecitina apresenta efeito citotóxico para as células tumorais humana de mama (MCF-7), pois inibiram o crescimento celular de forma significativa nos três períodos avaliados: 24, 48 e 72 horas. Além disso, as nanopartículas e os constituintes não são tóxicas para a célula e apresentaram boa estabilidade físico-química sob condições fisiológicas, o que indica sua possível aplicabilidade como sistema de liberação controlada de substâncias hidrofóbicas, como a curcumina, bem como a sua futura avaliação quanto a biodistribuição e efeito citotóxico em modelos in vivo. 


\section{REFERÊNCIAS BIBLIOGRÁFICAS}

AGGARWAL, S. et al. Curcumin (Diferuloylmethane) down-regulares expression of cell proliferation and antiapoptotic and metastát gene products through suppression of $\mathrm{IkB} \alpha$ Kinase and Akt activation. Cellular Signalling, v. 14, p. 649-654, 2002.

ALLEN JR. L; POPOVICH, N. G.; ANSEL, H. C. A. Formas farmacêuticas e sistemas de liberação de fármacos. 8.ed. São Paulo: Premier, 2007.

ALVARENGA, E. S. Characterization and Properties oh chitosan. Biotecnology of Biopolymers. n.5, p. 91-108, 2011.

ALVES, G. P.; MARTINS, F.; SANTANA, M. H. A. Nanotecnologia aplicada ao desenvolvimento de produtos farmacêuticos. Fármacos \& Medicamentos. São Paulo, ano 9, p. 44-50, 2008.

ANAND, P. et al. Biological activities of curcumin and its analogues (Congeners) made by man and mother nature. Biochemical PHarmacology, v. 76, p. 1590-1611, 2008.

ANITHA, A. et. al. Efficient water soluble O-carboxymethyl chotosan nanocarrier for the delivery of curcumin to cancer cells. Carbohydrate Polymers, v. 83, p. 452-461, 2011 a.

ANITHA, A. et al. Preparation, characterization, in vitro drug release and biological studies of curcumin loaded dextran sulphate-chitosan nanoparticles. Carbohydrate Polymers.v.84, p. 1158-1164, 2011b.

ANSARI, M. J.; AHMAD, S.; KOHLI, K.; ALI, J.; KHAR, R. K. Stability-indicating HPTLC determination of curcumin in bulk drug and pHarmaceutical formulations. Journal PHarm Biomed Anal, v. 39, n. 1-2, p. 132-138, 2005.

AULTON, M. A. Delineamento de formas farmacêuticas. 2 ed. São Paulo: Artmed, 2005.

AVGOUSTAKIS, K. et al. PLGA-mPEG Nanoparticles of cisplatin: In vitro Nanoparticles Degradation, In vitro Drug Release and In Vivo Drug Residence in Blood Properties. Journal Control Release, v. 79, n. 1-3, p. 123-135, 2002.

AZEVEDO, M. M. M. Nanoesferas e a liberação controlada de fármacos. In. Workshop Tópicos Especiais em Química Inorgânica IV - Introdução à Nanotecnologia: Um Enfoque Químico, São Paulo, 2002.

BACHMEIER, B. E. et al. Curcumin downregulates the inflammatory cytokines CXCL1 and2 in breast cancer cells via NFkB, Carcinogenesis, v. 29, n.4, p. 779-789, 2008.

BARRATT, G.M. Therapeutic applications of colloidal drug carriers. PHarma. Sci. Technol. Today, Cambridge, v.5, p.163-171, 2000. 
BARROS, F. C. F. et al. Produção e caracterização de esferas de quitosana modificada quimicamente. Revista Iberoamericana de Polímeros, v. 7, p. 232-246, 2006.

BASTOS, V. D. Biopolímeros e polímeros de matérias-primas renováveis alternativa aos petroquímicos. Revista do BNDES, Rio de Janeiro, v. 14, n. 28, p. 201-234, 2007.

BAYOMI, S. M.; EL-KASHEF, H. A.; EL-ASHMAWY, M. B.; NASR, M. N. A.; ELSHERBENY, M. A; BADRIA, F. A.;ABOU-ZEID, L. A.; GHALY, M. A.; ABDEL-AZIZ, N. I. Synthesis and biological evaluation of new curcumin derivatives as antioxidant and antitumor agents, Med Chem Res, v. 22, p. 1147-1162, 2013.

BERNABÉ-PINEDA, M., RAMÍREZ-SILVA, M. T., ROMERO-ROMBO, M., VERGANA, E. G., HERNÁNDEZ, A. R., Determination of acidity constants of curcumin in aqueous solution and apparent rate constant of its decomposition, Spectrochimica Acta Part A, v. 60, p. 1091 - 1097, 2004.

BOONSONGRIT, Y.; MITREVEJ, A.; MUELLER, B. Chitosan drug binding by ironic interaction. European Journal of PHarmaceutics and BiopHarmaceutics, v. 62, p. 267274, 2006.

BOTASSIO, SILVA. Níveis plasmáticos. 2010. Disponível em: Acesso em 25 maio 2015.

BOZTAS, A. O.; KARAKUZU, O.; GALANTE, G.; UGUR, Z.; KOCABAS, F.; ALTUNTAS, C. G.; YAZAYDIN, A. O. Synergistic Interaction of Paclitaxel and Curcumin with Cyclodextrin Polymer Complexation in Human Cancer Cells, Molecular pharmaceutics, v. 10, p. 2676-2683, 2013.

BROUSSIGNAC, J. Un hault polymere natural per connum dans I'industrie le chitosan, Chimie et industrie-Genie Chimique, v. 99, p. 1921, 1972.

BRUGNEROTTO, J.; LIZARDI, J.; GOYCOOLEA, F. M.; ARGUELLES-MONAL, W.; DESBRIÈRES, J. \& RINAUDO, M. An infrared investigation in relation with chitin and chitosan characterization. Polymer, v.42, n. 8, p.3569-3580, 2001.

BUSH, J. A., CHEUNG, K. J. LI, G. Curcumin induces apoptosis in human melanoma cells through a Fas receptor/caspases-8 pathway independent of 53. Experimental Cell Research, v. 271, p. 305-3014, 2001.

CALVO, P.; VILA-JATO, J. L.; ALONSO, M. J. Comparative in vitro evaluation of several colloidal systems, nanoparticles, nanocapsules and nanoemulsions, as ocular drug carries. Journal of PHarmaceutical Science, v. 85, n. 5, p. 530-536, 1996.

CAMPOS; V. E. B. Estudo da potencialidade de ácidos aminados encapsulados em nanopartículas de poli- $\varepsilon$-caprolactona para uso na Eletroterapia do câncer. Dissertação (Mestrado em Ciências Farmacêuticas) - Programa de Pós-Graduação em Ciências Farmacêuticas, Faculdade de Farmácia, Universidade Federal do Rio de Janeiro, 2008. Disponível em: < http://teses2.ufrj.br/Teses/FF_M/Vania EmerichBuccoDeCampos.pdf >. Acesso em 21 setembro 2014. 
CERAUlO, L., FANARA, S., LIVERIB, V. T., RUGGIRELlO, A., PANZERI, W., MELE, A. Orientation and molecular contacts of melatonin confined into AOT and lecithin reversed micellar systems. Colloids Surf A, v. 316, p. 307-312. 2008.

CHEN. C. et al. An in vitro study of liposomal curcumin: Stbility, toxicity and biological activity in human lympHocytes and Epstein-Barr virus-transformed human B-cells. International Journal of PHarmaceutics, v. 366, p. 133-139, 2006.

CLEASEN. C; WHILHELMS, T.; KULICKE, W. M. Formation and characterization of chitosan membranes. Biomacromolecules, v. 7, p. 3210-3222, 2006.

COELHO, L. P.; SERRA, M. F.; PIRES, A. L.; CORDEIRO, R. S.; RODRIGUES E SILVA, P. M.; Dos SANTOS, M. H.; MARTINS, M. A. 7-Epiclusianone a tetraprenylated benzopHenone, relaxes airway smooth muscle through activation of the nitric oxide-cGMP pathway. Journal of PHarmacology ond Experimental Therapeutics, v. 327, n. 1, p. 206214, 2008.

DALLAN, P. R. M. Síntese e caracterização de membranas de quitosana para aplicação na regeneração de pele. Campinas: Faculdade de Engenharia Química da Universidade Estadual de Campinas, 2005. 211p. (Tese, Doutorado em Engenharia Química, Desenvolvimento de Processos Biotecnológicos).

DANDEKAR, P.P.; JAIN, R.; PATIL, S.; DHUMAL, R.; TIWARI, D.; SHARMA, S.; VANAGE, G.; PATRAVALE, V. Curcumin-loaded hydrogel nanoparticles: Application in anti-malarial therapy and toxicological evaluation. PHarmaceut Nanotechnol, v.99, n. 12, p. 4992-5010, 2010b.

DASHA, M. et al. Chitosan-A versatible semi-synthetic polymer in biomedical applications. Progress in Polymer Science, v. 36, n. 981-1014, 2011.

De MARTIMPREY, H.; VAUTHIER, C.; MALVY, C.; COUVREUR, P. Polymer nanocarriers for the delivery of small fragments of nucleic acids: Oligonucleotides and siRNA, Eur. Journal PHarm. BiopHarm, v. 71, n. 3, p. 490-504, 2009.

DENG, C. M. et al. Biological properties of the chitosan-gelatin sponge wound dressing. Carbohydrate Polymers, v.69, p.583-589, 2007.

DES RIEUX, A. et al. Nanoparticles as potential oral delivery systems of proteins and vaccines: A mechanistic approach. Journal of Controlled Release, v. 116, p. 1-27, 2006.

DU, J.; DAI, J.; LIU, J.; DANKOVICH, T. Novel pH-sensitive polyelectrolyte carboximethyl Konjac Glucomannan-Chitosan beads as drug carriers. Reactive \& Functional polymers, v. 66, n. 1055-1061, 2006.

DURAN, N.; AZEVEDO, M. M. M.. O Que é Nanobiotecnologia? Atualidades e Perspectivas. Monografia LQES - Laboratório de Química do Estado Sólido - Instituto de Química - UNICAMP, 2002. Disponível em : http://lqes.iqm.unicamp.br. Acessado em 13 out.2014. 
DURAN, N.; DE AZEVEDO, M. M. M. Rede de Pesquisa em nanobiotecnologia. Disponível em: < http://www.comciencia.br/reportagens/nanotecnologia/nano20.htm>. Acesso em: 13 de Out. 2014.

EMERICH, D. F.; THANOS, C. G. The pinpoint promise of nanoparticle-based drug delivery and molecular diagnosis. Biomol Eng, v.23, n. 4, p.171-184, 2006.

FARJADO, A. R. Caracterização de complexos polieletróliticos de quitosana/sulfato de condroitina em diferentes condições de pH e tempos de imersão. 2009, $97 \mathrm{f}$. Dissertação (Mestrado em Química) - Departamento de Química, Universidade Estadual de Maringá, Maringá, 2009.

FERREIRA, H. S; RANGEL, M. C. Nanotecnologia: Aspectos gerais e potencial de aplicação em catálise. Química Nova, v. 32, n. 7, p. 1860-1870, 2009.

FEROZ, A. M.; MOSHAHID, A. R.; SANTOSH, K. K. Oral delivery of curcumin bound to chitosan nanoparticles cured Plasmodium yoelli infected mice. Biotechnology advances, 2011.

FILHO, A. B. C. et al. Cúrcuma: planta medicinal, condimentar e de outros usos potenciais. Ciência Rural, Santa Maria, v. 30, n. 1, p. 171-177, 2000.

FOOT, M.; MULHOLLAND, M. Classification of condroitina sulfate A, Chondroitin sulfate $\mathrm{C}$, glucosamine hydrochloride and glucosamine 6 sulfate using chemometric techniques, Journal of PHarmaceutical and Biomedical Analyses, v. 38, p. 397-407, 2005.

FOROUZANFAR, M.; SHARAFI, M.; HOSSEINI, S. M.; OSTADHOSSEINI, S.; HAJIAN, M.; HOSSEINI, L.; ABEDI, P.; NILI, N.; RAHMANI, H. R.; NASR-ESFAHANI, M. H. In vitro comparison of egg yolk-based and soybean lecithin-based extenders for cryopreservation of ram semen, Theriogenology, v. 73, n. 4, p. 480-487, 2010.

FUKUI, Y.; KOHNO, H.; TOGARI, T.; HIWASA, M.; OKABE, K. Fertility after artificial insemination using a soybean-based sêmen extender in sheep. Journal of Reproduction and Development, v. 54, n. 4, p. 286-289, 2008.

GARNJANAGOONCHORN, W.; WONGEKALAK, L.; ENGKAGUL, A. Determination of chondroitin sulfate from different sources of cartilage. Chemical Engineering and Processing, v. 46, p. 465-471, 2007.

GATTI, A.; RIVASI, F. Nanotecnology and control delivery systems of drugs. Biomaterials, v. 23, p. 23-81, 2002.

GENNARO, A. R. Remington. A ciência e a prática da farmácia. 20 ed. Rio de Janeiro: Guanabara Koogan, 2004.

GEORGE, M.; ABRAHAM, T. E. Polyonic hydrocolloids for intestinal delivery of protein drugs: Alginate and chitosan - a review. Journal Controlled Release, v. 114, p. 1-14, 2008.

GOMES, A. S.; MELO, C. P. First Brazilian Winter School on Nanobiotechnology - Rede Nanobiotec, Campinas; São Carlos; Ribeirão Preto, v. 1, p. 146, 2002. 
GONSALVES, A. A. et al. Diferentes estratégias para a reticulação de quitosana. Química Nova, v. 34, n. 7, p. 1215-1223, 2011.

GOOSEN, M. F. A. Applications of chitin and chitosan. Lancaster: Technomic, 336p, 1997.

GOVENDER, T.; STOLNIK, S.; GARNETT, M. C.; ILlUM, L.; DAVIS, S. S. PLGA nanoparticles prepared by nanoprecipitation: drug loading and release studies of a water soluble drug. J. Controlled Release, v. 57, n. 2, p. 171-185, 1999.

GUINEBRETIÈRE, M. H.; BROUSSOLE, V., NGUYEN-THE, C. Enterotoxigenic profiles of food-poisoning and food bourne Bacillus cereus strains. J Clin Microbiol, v.40, p. 30533056, 2002.

GUTERRES, S. S.; ALVES, M. P.; POHLMANN, A. R. Polymeric Nanoparticles, NanospHeres and Nanocapsules, for Cutaneous Applications. Drug Target Insihts, v. 2, p. 147-157, 2007.

HAMERSKI, L.; REZENDO, M. J.; SILVA, B. V. Usando as cores da natureza para atender aos desejos do consumidor: substâncias Naturais como Corantes na Indústria Alimentícia. Revista Virtual de Química, v. 5, n. 3, p. 394-420, 2013.

HARLAND, R. S.; GAZZANIGA. A.; SANGALli, M. E.; COLOMBO, P.; PEPPAS, N. A. Drug: polymer matriz swelling and dissolution, Pharm. Res. v. 5, n. 8, p. 488-494, 1988.

HENRIQUE, J. S.; FALCARE, R. S.; LOPES, P. S. Sistemas de Liberação Controlada. Pharmacia Brasileira, v. 56, p. 22, 2006.

HERRERO-VANRELL, R.; RINCÓN, A. C.; ALONSO, M.; REBOTO, V.; MOLINAMARTINEZ, I. T.; RODRIGUEZ-CABELLO, J. C. Self-assembled particles of na elastinlike polymer as vehicles for controlled drug release, Journal of controlled Release, v. 102, p. 113-122, 2005.

HUN-YU TSAI, CHIEN-CHIH CHIU, PING-CHIH LIN, SU-HWEI CHEN, SHIHJER HUANG, LI-FANG WANG. Antitumor Efficacy of Doxorubicin Released from Crosslinked Nanopartículate Chondroitin Sulfate/Chitosan Polyelectrolyte Complexes. Macromolecular Bioscience, v. 11, n. 5, p. 680-688, 2011.

JARDIM, K. V. Desenvolvimento de nanopartículas de quitosana / sulfato de condroitina para nanoencapsulação da curcumina visando a sua liberação controlada e avaliação de sua atividade antitumoral. 2013, 116f. Dissertação (Mestrado em Ciências de Materiais) Faculdade UnB Planaltina, Universidade de Brasília, Brasília, 2013.

JOE, B., VIJAYKUMAR., LOKESH, R. B. Biological properties of curcumincellular ond molecular mechanisms of action. Critical Reviews in Food Science and Nutrition, v. 44, p. 97-111, 2004.

JOHNSON, D. W.; MOKLER, D. J. Chondroitin sulfate. Continuing Education Module. New Hope Institute of Retailing, 2001. 
KAPARISSIDES, C.; ALEXANDRIDOU, S.; KOTTI, K.; CHAITIDOU, S. Recent advances in novel drug delivery systems. J. Nanotechynol. Online, v.2, p.1-11, 2006.

KELMANN, R. G.; KUMINEK, G; TEIXEIRA, H.; KOESTER, L. S. Carbamazepine parenteral nanoemulsions prepared by spontaneous emulsification process. International Journal of PHarmaceutics, v. 342, p. 231-239, 2007.

KORSMEYER, R. W., GURNY, R.; DOELKER, E.; BURI, P.; PEPPAS, N. A. Mechanism of solute release from porous hydrophilic polymers. Int. J. Pharm. v. 15, p. 25-35, 1983.

KUMAR, M. N. V. R. et al. Chitosan chemistry and pharmaceutical perspectives. Chemical reviews, v. 104, n. 12, p. 6017-6084, 2004.

KUNNUMAKKARA, A. B.; ANAND, P.; AGGARWAL, B. B. Curcumin inhibits proliferation, invasion, angiogenesis andmetastasis of different cancers through interaction with multiple cell signaling proteins. Cancer Letters, Limerick, v. 269, n. 2, p. 199-225, 2008 .

KURRIEN, B. T. et al. Improving the solubility and pHarmacological efficacy of curcumin by heat treatment. Assay and drug development Technologies, v. 5, p. 567-576, 2007.

LARANJEIRA, M. C. M. FÁVERE, V. T. de. Quitosana: biopolímero funcional com potencial industrial biomédico. Química Nova, v. 32, n. 3, p. 672-678, 2009.

LEGRAND, P. et al. Influence of polymer behavior in organic solution in the production of polylactide nanoparticles by nanoprecipitation. International Journal of PHarmaceutics, $v$. 344, p. 33-43, 2007.

LEITE, J. P. V.; PIMENTA, D. S.; GOMES, R. S. D. L.; DANTAS-BARROS, A. M. Contribuição ao estudo farmacobotânico da Echinodorus macrophyllus (Kunth) Micheli (chapéu-de-couro) - Alismataceae. Braz. J. Pharmacogn., João Pessoa, v. 17, p. 242-8, 2007.

LETCHFORD, K. et al. Solubilization of hydropHobic drugs by methoxy poly(ethyleneglycol)-block-polycaprolacyone diblock copolymer micelles: Thei=oretical and experimental data and correlations. Journal PHarmaceutical Science, 2007.

LI, N.; PARSONS, B. L.; LIU, D.; MATTOO, A. K. Accumulation of wound-inducible ACC synthase transcript in tomato fruit is inhibited by salicylic acid and polyamines. Plant Molecular Biology, v. 18, n. 3, p. 477-487, 1992.

LIU, F.; QUESADA, V.; CREVILLÉN, P.; BÁURIE, I.; SWIEZEWSKI, S.; DEAN, C. The Arabidopsis RNA-Binging Protein FCA Requires a Lysine-Specific Demethylase 1 Homolog to Downregulate FLC, Molecular Cell, p. 398-407, 2007.

LOPES, L. C.; PIAI, J. F.; FARJADO, A. R.; RUBIRA, A. F.; MUNIZ, E. C. Propriedades de hidrogéis constituídos de quitosana e sulfato de condroitina na presença de teofilina intumescidos em diferentes pHs. Anais do $10^{\circ}$ Congresso Brasileiro de Polímeros, Paraná, 2009*. 
MA, Z. et al. High-performance liquid chromatograpHy analysis of curcumin in rat plasma: application to pHarmacokinetics of polymeric micellar formulation of curcumin. Biomedical ChrmatograpHy, v. 21, p. 5. 546-552, 2007.

MACIEL, A. P. M; LONGO, E.; LEITE, E. R. Dióxido de estanho nanoestruturado: Síntese e crescimento de nanocristais e nanofibras. Química Nova, v, 26, p.855-862, 2003.

MAHESHWARI, R. K. et al. Multiple biological activities of curcumin: a short review. Life Science, v. 78, p. 2081-2087, 2006.

MAITI, L. et al. Curcumin-pHospHolipid complex: Preparation, therapeutic evaluation and pHarmacokinetic study in rats. International Journal of PHarmaceutics, v. 330, n. 1, p. 155-163, 2007.

MAJETI, N. V.; KUMAR, R. A review of chitin and chitosan applications. Reactive and functional Polymers, v. 46, p. 1-27, 2000.

MARCELINO, J.; LIMA, J. L. F. C.; REIS, S.; MATOS, C. Assessing the effects of surfactants on the pHysical properties of liposome membranes. Chemistry and PHysics of Lipids, v. 146, p. 94-103, 2007.

MARTINS, M. C.; RUSIG, O. Cúrcuma - um corante natural. Boletim da Sociedade Brasileira de Tecnologia de Alimentos, v. 26, p. 53-65, 1992.

MARTINS, P. R. Nanotecnologia , Sociedade e Meio Ambiente no Brasil: Perspectivas e Desafios. 2008.2 Disponível em: <http://www2.faac.unesp.br/pesquisa/lecotec/eventos/lecotec2009/anais/11401153MARTINF ERNANDES.pdf >. Acesso em 26 mar. 2014.

MAZZARINO, L. Desenvolvimento de sistemas nanoestruturados contend curcumina e avaliação in vitro e in vivo em modelo de melanoma murinho B16-F10. 2009. $157 \mathrm{f}$. Dissertação (Mestrado em Fármacia) - Centro de Ciência da Saúde, Universidade Federal de santa Catarina, Florianópolis, 2009.

MESA, M. D.; RAMÍREZ-TORTOSA, M. C.; AGUILERA, C. M.; RAMÍREZ-BOSCÁ, A. Y GIL, A. Efectos farmacológicos y nutricionales de los extractos de Curcuma longa L. y de los cucuminoides. Ars PHarmaceutica, v. 41, n. 3; p. 307-321, 2000.

MILIOLI, C. C . Avaliação da atividade antimicrobiana da quitosana em pó dopada com prata. Dissertação (Mestrado). Universidade Federal de Santa Catarina, Centro Tecnológico, Programa de Pós-graduação em Engenharia Química. Florianópolis, 2011.

MOHANRAJ, V. J.; CHEN, Y. Nanoparticles - Areview. Tropical Journal of PHarmaceutical Research, Stuttgart, v. 5, n. 1, p. 561-573, 2006.

MOREIRA, A. N.; DEL PINO, F. A. B; VENDRUSCULO, C. T. Estudo da produção de biopolímeros via enzimática por meio da inativação e lise celular e com células viáveis de Beijerinckia sp. 7070. Ciência e tecnologia de Alimentos, v. 23, n. 2, p. 300-305, 2003. 
MOURA, M. J. Aplicações de quitosano em liberação controlada de fármacos: algumas considerações. In: Enciclopédia Biosfera. Goiânia: Centro Científico Conhecer, v. 8, n. 14, p. 1489, 2012.

MULLER, V. et al. Preparação e caracterização de microesferas constituídas de quitosana e zeina, como matrizes poliméricas para posterior liberação controlada de fármacos. Anais do $1^{\circ}$ Congresso Brasileiro de Polímeros. Foz do Iguaçu, PR, out, 2009.

MUNDAY, D. L.; COX, P. L. Compresses xanthan and karaya gum matrices hydration, erosion and drug release mechanisms. Int. J. Pharm., v. 203, p. 179-192, 2000.

NASIR, M. I.; BERNARDS, M. A.; CHARPENTIER, P. A. Acetylation of soybean lecithin and identification of components for solubility in supercritical carbon dioxide. Journal of Agricultural and Food Chemistry, v. 55, n. 5, p. 1961-1969, 2007.

NETO, C. G. T et al. Thermal analysis of chitosan based networks. Carboydrates Polymers, v. 62 , p. 97-103, 2005.

NING, L. et al. Down-regulation of Notch signaling inhibits tumor growth in human hepatocellular carcinoma. American Journal of translational Research, Madison, v. 1, n. 4, p. 358-366, 2009.

ODOT, J. et al. In vitro and in vivo anti-tumoral effect of curcumin against melanoma cells. International Journal af cancer, v. 111, p. 381-387, 2004.

OURIQUE, A. F.; POHLMANN, A. R.; GUTERRES, S. S.; BECK, R. C. R. Tretinoinloaded nanocapsules: Preparation, pHysicochemical characterization, and pHotostability study. Int. J. PHarm. v.1, p 352, 2008.

OZTURK, K.; CABAN, S.; KOZLU, S.; KADAYIFCI, E.; YERLIKAYA, F. \& CAPAN, Y. The influence of technological parameters on the pHysicochemical properties of blank PLGA nanoparticles.PHarmazie, v. 65, p. 665 - 669, 2010.

PACE, A.; SAVARESE, A.; PICARDO, M.; MARESCA, V.; PACETTI, U.; DEL MONTE, G.; BIROCCIO, A.; LEONETTI, C.; JANDOLO, B.; COGNETTI, F.; BOVE, L. Neuroprotective effect of vitamin $\mathrm{E}$ supplementation in patients treated with cisplatin chemotherapy. Journal of Clinical Oncology, New York, v. 21, n. 5, p. 937-931, 2003.

PAN, Y. et al. Bioadhesive polysaccharide in protein delivery system: chitosan nanoparticles improve the intestinal absorption of insulin in vivo. International Journal of PHarmaceutics, v. 249, p. 139-147, 2002.

PAN, Y. H. J. et al. Preparation, characterization and anticoagulation of curcumin-eluting controlled biodegradable coating stents. Journal of Controlled Release, v. 116, p. 42-49, 2006.

PAVAO, M. S. G.; VILELA-ILVA, A. C.; MOURAO, P. A. S. Biosynthesis of chondroitin sulfate: from the early precursor discoveries to nowadays, genetics approaches. Advances in PHarmacology, v. 3, 2006. 
PAVELIC, P., B. NICHOLSON, P. DILLON, AND K. BARRY. Fate of disinfection byproducts in groundwater during aquifer storage and recovery with reclaimed water. $\mathbf{J}$. Contam. Hydrol., v.77, p. 351-373, 2005.

PENICHE, C.; FERNANDEZ, M.; RODRIGUEZ, G. Cell supports of chitosan/hyaluronic acid and chondroitin sulpHate system morpHology and biological behaviour. Journal of Materials Science. Materials in Medicine, v. 18, p. 1719-1726, 2007.

PEPPAS, N. A.; SAHLIN, J.J. A simple equation for descripton of solute release. III. Coupling of diffusion and relaxation. Int. J. Pharm., v. 57, p. 169-172, 1989.

PERALT- ALMEIDA, L. et al. Atividade antimicrobiana de diferentes extratos de Curcuma Longa L. $2^{\circ}$ Simpósio em Ciência de Alimentos. SIMPOCAL/SBCTA. Florianópolis, SC, 28-30 maio de 2003.

PFEIFFER, E.; HOHLE, S.; SOLYOM, A. M.; METZLER, M. Studies on the stability of turmeric constituents. Journal of food Engeineering, ed. 56, p. 527-529, 2003.

PIAI, J. F.; RUBIRA, A. F.; MUNIZ, E. C. Self-assembly of a swollen chitosan/chondroitin sulfate hydrogel by outward diffusion of the chondroitin sulfate chains. Acta Biomaterialia, v. 5, p. 2601-2609, 2009.

POTHAKAMURY, U. R., BARBOSA-CANOVÁS, G. V. Fundamental aspects of controlled release in foods, Trends in food Science e technology, v. 6, 1995.

QUIN, C. et al., Water-solubility of chitosan and its antimicrobial activity. Carbohydrate Polymers, v. 63, p. 367-374, 2006.

QUINTANAR-GUERRERO, D.; ALLÉMANN, E.; FESSI, H.; DOELKER, E. Preparation techniques and mechanisms of formation of biodegradable nanoparticles from preformed polymers. Drug Dev. Ind.PHarm., v. 24, p. 1113- 1128, 1998.

RAFFIN, R. P. et al. Nanocápsulas poliméricas secas contendo indometacina: Estudo de formulação e de tolerância gastrointestinal em rato. Acta farmacêutica Bonaerense, p. 163$172,2003$.

REINECCIUS, G. A.; WHORTON, C. Evalution of the mechanism associated with the release of encapsulation flavor materials from maltodrextrin matrices. In: Encapsulation and Controlled Release of food Ingredients. Risch, S. J. and Reineccius, G. A. Eds., American Chemical Society, Washington, DC, p. 143-160, 1995.

REIS, P. C. et al. Nanoencapsulation I: Methods for preparation of drugs-loaded polymeric nanoparticles. Nanomedicine Journal, v. 2, p. 8-21, 2006.

REIS, R. C. N. Síntese de surfactantes derivados da D-ribonolactona. 162f. Dissertação (Mestrado em Química) - Universidade Federal de Juíz de Fora, Minas Gerais, 2007.

RICHY, F. et al. Structuraland symptomatic efficacy of glucosamine and chondroitin in knee osteoarthritis: A comprehensive meta-analysis. Archives of Internal Medicine, v. 163, p. 1514-1522, 2003. 
RITGER, P. L., PEPPAS, N. A. S simple equation for description of solute release. I . Fickian and non-Fickian release from nonswellable devices in the from of slabs, spheres, cylinders or dises, Journal od Controlled Release, v. 5, p. 25-36, 1987a.

RITGER, P. L., PEPPAS, N. A. S simple equation for description of solute release.II. Fickian and anomalous release from Swellable Devices, Journal od Controlled Release, v. 5, p. 37-42, $1987 \mathrm{~b}$.

RINALDO, M. Chitin and Chitosan: properties and applications. Progress in Polymer Science, v. 31, p. 603-632, 2006.

ROBERT, G. A. F. Chtitin chemistry, Macmillan, London, v. 14 n. 3, p.166-169, 1992.

RODRIGUES, G. S. et al. PHysicochemical parametrs associated with nanoparticle formation in the salting-out, emulsificationdiffusion, and nanoprecitation methods. PHarmaceutical Research, v. 21, p. 1428-1439, 2004.

RODRIGUES, V. M.; SOARES, A. M.; MANCIN, A. C.; FONTES, M. R. M.; HOMSIBRANDEBURGO, M. I.; GIGLIO, J. R. GeograpHic variations in the composition of myotoxins from Boothrops neuwiedi snake venoms: biochemical characterization and biological activity. Comp. Biochem. PHysiol, v, 121, p. 215-222, 1998.

ROMIO, Ana P. et al. Nanocápsulas biocompatíveis via polimerização em miniemulsão usando surfactante e hidrófobo biodegradáveis. Congresso Brasileiro de Polímeros, 9., Campina Grande, Anais, 2007.

ROSEMAN, S. Reflections on glycobiology. Journal Biological Chemistry, v. 276, p. 4152741542,2001.

ROY, D. S.; ROHEIRA, B. D. Comparative evaluation of rate of hydration and matrix erosion of HEC and HPC, and study of drug release from their matrices. Eur. J. Pharm. Sci. v. 16, p. 193-199, 2002.

SAHOO S. K.; LABHASETWAR, V. Nanotech approaches to drug delivery and imaging. Drug Discov Today, v. 8, p. 1112-1120, 2003.

SALES, L. L. M.; SOUZA, A. G.; SOLEDADE, L. E. B.; SANTOS, I. M. G.; NETO, J. B. R.; LONGO, E.; PASKOCIMAS, C. A. Influência do pH sobre a estabilidade de suspensões de alumina estabilizadas eletrostericamente. Química Nova, v. 30, n. 1, p. 70-74, 2007.

SANTOS, A. B., FERREIRA, V. P., GROSSO, C. R. F., Microcápsulas - uma alternativa viável (Microencapsulação de produtos sensíveis à oxidação: óleoresina de páprica), Biotecnologia Ciência \& Desenvolvimento. N.16, ano 3, p. 26-30, 2000.

SANTOS, C. V. Sulfato de Condroitina: da matéria-prima à terapêutica. 2009. $79 f$. Monografia (Graduação) - Medicina Veterinária. Faculdade de Veterinária da Universidade Federal do Rio Grande do Sul, 2009. 
SANTOS, J. S. Nanopartículas: Aplicações cosméticas e farmacêuticas. São Paulo: PHarmabooks, 2010.

SCHAFFAZICK, S. R.; GUTERES, S. S. Caracterização e estabilidade físico-química de sistemas poliméricos nanopartículados para administração de fármaco. Química Nova, v, 26, n. 5, p. 726-737, 2003.

SCHUBERT, M. A.; HARMS, M.; MULLER-GOYMANN, C. C. Structural investigations on lipid nanoparticles containing high amounts of lecithin. Eur. J. PHarm. Sci., v. 27, n. 1-3, p. 226-236, 2006.

SEVERINO, P., SANTANA, M. H.; MALMONGE, S.M.; SOUTO, E.B. Polímeros usados como sistemas de transporte de princípios ativos. Polímeros, v.21, n.5, p.361-368, 2011.

SHARMA, R. A.; GESCHER, A. J.; STEWARD, G. W. P. Curcumin: the story so far. European Journal of cancer, v. 41, p. 1955-1968, 2005.

SHI, M. et al. Antiproliferation and apoptosis unduced by curcumin in human ovarian cancer cells. Cell Biology International, v. 30, p. 221-226, 2006.

SHINDE, S; MALVE, M.; CHAUHAN, P; GARAD, M.V. Nanotechnology and Forensic Science. Bioinfo- Nanotechnology and Nanoscience, Índia, v.1, p.19-21, 2010.

SHISHODIA, S.; SETHI, G.; AGGARWAL, B. B. Curcumin: Getting Back to the Roots. Annals of the New York Academy of Sciences, v. 1056, p. 206-217, 2005.

SIEPMANN, J.; PEPPAS, N. A. Modeling of drug delivery systems based on hydroxipropyl methylcellulose (HPMC), Advance Drug Delivery Reviews, v. 48, p. 139-157, 2001.

SILVA, C. G. O Programa Nacional de Nanotecnologia e o Centro Nacional de Referência em Nanotecnologia. 2003. Disponível em: Acessado em 05 agosto 2014.

SILVA, Hélio S. R. C; SANTOS, K. S. C. R.; FERREIRA, E. I. Quitosana: derivados hidrossolúveis, aplicações farmacêuticas e avanços. Química Nova, v. 29, n. 4, p. 776-785, 2006.

SILVA, O. G. Hidroxiapatita mesoporosa pura e modificada organicamente com grupos nitrogenados - síntese, caracterização e uso como carreadora de fármacos. Tese (Doutorado em química) - Universidade Federal de Pernambuco, João Pessoa, 2010.

SIQUEIRA, J. R.; GASPAROTTO, L. H. S.; CRESPILHO, F. N., et al. "Physicochemical Properties and Sensing Ability of Metallophthalocyanines/Chitosan Nanocomposites". The Journal of Physical Chemistry B, v. 110, n. 45, p. 22690-22694, 2006.

SKOOG, WEST, HOLLER, CROUCH, Fundamentos de Química Analítica, Tradução da $8^{a}$ Edição norte-americana, Editora Thomson, São Paulo-SP, 2006.

SOARES, G. A. Biomateriais. Centro de Gestão e Estudos Estratégicos, Ciência Tecnologia e Inovação. Disponível em: <http://www.anbio.org.br/pdf/2/tr10_biomateriais.pdf>. Acesso em: 15 out. 2013. 
SOGIAS, I. A.;; WILLIAMS, A. C.; KHUTORYANSKIY, V. Why is chitosan mucoashesive?. Biomacromolecules, v. 9, n. 7, p. 1837-1842, 2008.

SOLERLLIA, G.J.A.A.; SANCHEZ, C.; LEBEAU, B.; PATARIN, J. Chemical strategies to design textured materials: from microporous and mesoporous oxides to nanonetworks and hierarchical structures. Chemical Review, v. 102, p. 4093- 4138, 2002.

SONVICO, F.; CAGNANI, A., ROSSI, A., MOTTA, S., DI BARI, M.T.,CAVATORTA, F., ALONSO, M.J., DERIU, A., COLOMBO, P. Formation of self-organized nanoparticles by lecithin/chitosan ionic interaction. International Journal of PHarmaceutics, v. 324, p. 67 73, 2006.

SOPPIMATH, K. S. et al. Biodegradable polymeric nanoparticles as drug delivery devices. Journal of controlled Release, USA, v. 70, p. 1-20, 2001.

SORLIER, P.; DENUZIERE, A.; VITON, C.; DOMARD, A. Relation between the degree of acetylation and the electrostatic properties of chitin and chitosan, Biomacromolecules, v. 2, p. 765-772, 2001.

SOUZA, C. R. A. Cúrcuma: caracterização, extração e estabilidade. 78f. Dissertação (Mestrado em Ciência de Alimentos) - Escola de Veterinária, Universidade Federal de Minas Gerais, 1993.

SUNDAR, D.; KUNDU. J.; KUNDU, S. C. Biololymeric nanoparticles. Science and Technology of advance Materials, v. 11, p. 104-113, 2010.

SYNOWIECKI J AND NA AL-KHATEEB. Production, properties, and some new applications of chitin and its derivatives. Crit Rev Food Sci Nutr, v. 43, p.145-171, 2003.

TAGLIARI, M. P. Desenvolvimento de nanopartículas de quitosana e alginato de sódio para incorporação de ácido glicirrizico, ácido salicílico ou cafeína visando a liberação tópica. 2012. 229 f. Tese (Doutorado em Ciências Farmacêuticas) - UFSC, Santa Catarina, 2012.

TAHARA, K.; FURUKAWA, S.; YAMAMOTO, H. \& KAWASHIMA Y. Hybrid-modified poly(D,L-lactide-co-glycolide) nanospHeres for a novel cellular drug delivery system. Int. J. PHarm., v.392, p. 311, 2010.

TAN, K. H. Soil sampling preparation, and analysis. New York: Marcel Dekker, Inc., p. 278-298, 1996

TANER, G.; Yesiloz, R.; VARDAR, D. O.; Senyigit, T.; Ozgen, O.; Degen, G. H.; BASARAN, N. Evaluation of the cytotoxic and genotoxic potential of lecithin/chitosan nanoparticles, J Nanopart Res, v. 16, p. 2216-2220, 2014.

TOFFOLETTO, O.; TAVARES, A.; CASARDI, D. E.; REDUBLO, B. M.; RIBEIRO, A. B.; Farmacocinética da associação de glucosamina e sulfato de condroitina em humanos sadios do sexo masculino. ACTA Ortopedica Brasileira, v.5, p. 13, 2005. 
TOMREN, M. A.; MASSON, M.; LOFTSSON. T.; TONNESEN, H. H. Studies on curcumin and curcuminoids: XXXI. Symmetric and asymmetric curcuminoids: Stability, activity and complexation with cyclodextrin. Int J PHarm, v. 338, p. 27-34, 2007.

TIYABOONCHAI, W. Chitosan Nanoparticles. A Promising System for Drug Delivery. Naresuan University Journal, v. 11, n. 3, p. 51-66, 2003.

TONHI, E.; PLEPIS, A. M. G. Obtenção e caracterização de blendas de colágeno-quitosana. Química Nova, v. 25, n. 6, p. 943-948, 2002.

TONNESEN, H. H.; KARLSEN, J. Studies on curcumin and curcuminoids. VI. Kinetics of curcumin degradation in aqueous solution. Z Lebensm Unters Forsch. v. 180(5), p. 402-4. 1985.

TONNESEN, H. H.; MASSON, M.; LOFTSSON, T. Studies of curcumin and curcuminóides, XXVII Cyclodextrin complexation solubility, chemical and pHotochemical stability. Int. J. PHarmacautics, v. 244, n. 1-2, p. 127-135, 2002.

TSAI, H-Y, et al. Antitumor Efficacy of Doxorubicin Released from Crosslinked Nanopartículate Chondroitin Sulfate/Chitosan Polyelectrolyte Complexes. Macromolecular Bioscience, v. 11, p. 680-688, $2011 \mathrm{a}$.

VAUTHIER, C.; DUBERNET C.; FATTAL, E.; PINTO-ALPHANDARY, H.; COUVREUR, P. Poly(alkylcyanoacrylates) as biodegradable materials for biomedical applications. Advance Drug Delivery Reviews, v. 55, n. 4, p. 519-548, 2003.

VELOSO, W. P. Nanotecnologia geral e na computação. 2007. Disponível em: <http://www.waldirdepinhoveloso.com/artigos/nanotecnoligiageral.pdf.> Acesso em $13 \mathrm{de}$ Outubro de 2013.

WAN, Y.; ZHAO, D. On the controllable soft-templating approoch to mesoporous silicates, Chemical Reviews, v.107, p. 2821-2860, 2007.

WANG, D. A.; VARGHESE, S.; SHARMA, B. Multifunctional chondroitin sulpHate for cartilage tissue-biomaterial integration. Nature Materials, v. 6, p. 385-392, 2007.

WANG, M. S. et al. Curcumin reduces alpHa-synuclein induced cytotoxicity in Parkison's disease cell model. BMC Neuroscience, London, v. 11, p. 1-10, 2010.

WANNMACHER, L. Evidências sobre o uso de antibacterianos nas infecções respiratórias altas. Uso Racional de Medicamentos: Temas Selecionados, v. 4, n. 1, p. 1-6, 2006.

WEIR, N. M. et al. Curcumin induces G2/M arrest and apoptosis in cisplatin-resistant human ovarian cancer calls by modulating Akt and p38 MAPK. Cancer Biology \& Therapy. Geordetown, v. 6, n. 2, p. 178-184, 2007.

WHEATLEY, M. A. \& LEWANDOWSKI, J. Hybrid-modified poly(D,Llactide-co-glycolide) nanospHeres for a novel cellular drug delivery system. Mol. Imaging. v. 9, p. 96, 2010. 
WHORTON,C. Factors influencing volatile release from encapsulation matrices. In: Encapsulation and Controlled Release of food Ingredients. Risch, S. J. And Reineccius, G. A., Eds., American Chemical Society, Washington, DC, p.134 - 142, 1995.

YALLAPU, M. M. et al. Scope of nanotechnology in ovarian cancer therapeutics. Journals of ovarian research, v. 3, n. 19. p. 1-10, 2010.

YEH, M. K. et al., Novel protein loaded chondroitin sulfate-chitosan nanoparticles: Preparation and characterization. Acta Biomaterialia, v. 7, p. 3804-3812, 2011.

ZEBIB, B.; Z. MOULOUNGUI, AND NOIROT, V. Stabilization of curcumin by complexation with divalent cations in glycerol/water system, Bioinorganic Chemistry and Applications, p. 1-8, 2010.

ZHANG, J. et al. Desing of nanoparticles as drug carries for cancer therapy, Cancer Genomics \& Proteomics, v. 3, p. 147-158, 2006.

ZHI-DONG, L.; XIANG-PING L.; WEI-JUN, Z.; QIAN, D.; FU-NIAN, L.; HAI-BO, W.; BIN, K. Curcumin induces apoptosis in breast cancer cells and inhibits tumor growth in vitro and in vivo, Int J Clin Exp Pathol, v. 7, n. 6, p. 2818-2824, 2014.

ZOHURIAN, M. J.; SHOKROLARI, F. Thermal studies on natural and modified gums. Polymer Testing, v. 23, p. 575-579, 2004.

ZOU, X. H. JIANG, Y. Z.; ZANG, G. R. Specific interactions between human fibroblast and particular chondroitin sulphate molecules for wound healing. Acta Biomaterialia, p. 14727061, 2009.

ZHOU, Q.; WANG, X.; LUI, X.; ZANG, HUI.; LU, Y.; SU, S. Curcumin enhanced antiproliferative effect of mitomycin $\mathrm{C}$ in human breast cancer MCF-7 cells in vitro and in vivo. Acta Pharmacologica Sinica, v.32, p. 1402-1410, 2011. 